\title{
BLACK SHALE DEPOSITION AND EARLY DIAGENETIC DOLOMITE CEMENTATION DURING OCEANIC ANOXIC EVENT 1: THE MID-CRETACEOUS MARACAIBO PLATFORM, NORTHWESTERN SOUTH AMERICA
}

\author{
DANIEL A. PETRASH* ${ }^{*}$, NUR GUENELI**, JOCHEN J. BROCKS**, \\ JOSÉ A. MÉNDEZ-DOT***, GABRIELA GONZÁLEZ-ARISMENDI**," \\ SIMON W. POULTON ${ }^{\S}$, and KURT O. KONHAUSER*
}

\begin{abstract}
Thin laterally continuous organic-rich dolomitic marlstones were deposited in the extended Late Aptian - Early Albian epicontinental sea of northwestern South America. These intervals are the proximal equivalents of thick hemipelagic black shale-ammonitic floatstone couplets, deposited in the distally stepped, differentially subsiding part of the Maracaibo Platform. The marlstones reflect the dynamic conditions resulting from orbital forcing mechanisms and can be genetically related to (1) minor sea-level changes, (2) proximal turnovers in marine productivity, and (3) sudden climate shifts affecting mid-Cretaceous shoaling upward, shallow marine, carbonate cyclicity. Therefore, the marlstones may well be linked to the multiple environmental perturbations collectively referred to as Oceanic Anoxic Event 1. The interstitial euhedral dolomite has a medium crystallinity, and exhibits unusual textural relations with framboidal pyrite and gypsum. The authigenic mineral assemblage also includes quartz, Ca-F apatite, and barite, which together with the chemical signals of dolomite, point to an unsteady climate regime. Bulk-rock biomarker parameters, rare earth element geochemistry, and iron speciation data point to widespread photic zone anoxia and transient shallow marine euxinia by the time of deposition, with climatic instability driving the delivery of oxidized detritus from the hinterlands. These conditions led to a schizohaline redox stratified environment favorable to dolomite precipitation. In such a depositional setting, the bio-utilization of $\mathrm{Fe}, \mathrm{Mn}$, and sulfur for organic matter respiration sustained elevated pore-water alkalinity and $\mathrm{pH}$, and allowed for the pre-compactional growth of interstitial dolomite.
\end{abstract}

Keywords: black shale, marlstone, dolomite, diagenesis, OAE 1, Maracaibo Platform

INTRODUCTION

The widespread deposition of black shale intervals during the mid-Cretaceous has been linked to multiple paleoenvironmental perturbations, potentially resulting from the emplacement of large igneous provinces (Arthur and others, 1985; Hay and others, 2006; Tejada and others, 2009; Monteiro and others, 2012, Naafs and others, 2016). Such tectono-magmatic pulses augmented atmospheric concentrations of $\mathrm{CO}_{2}$, which led to intensified rates of erosion and phosphate delivery to the oceans (Kump and Arthur, 1999). The hydrothermal activity related to these pulses also increased the concentrations of dissolved bioessential metals in seawater (Larson and Erba, 1999), leading to transient nutrient-rich conditions that fostered greater organic productivity in the upper water column (Kuypers and others, 2001; Leckie and others, 2002; Herrle and others, 2003). In turn, this led to the development of anoxic bottom waters that were ideal for the deposition of sediments exceptionally rich in organic matter. This sequence of events led to what is generally referred to as an "Oceanic Anoxic Event

\footnotetext{
* Department of Earth and Atmospheric Sciences, University of Alberta, Edmonton T6G 2E3, Canada ** Research School of Earth Sciences, Australian National University, Canberra ACT 2601, Australia *** Escuela de Geología, Minas y Geofísica, Universidad Central de Venezuela, Caracas, Venezuela \# Currently at PRG, Department of Geoscience, University of Calgary, Calgary T2N 1N4, Canada $\S$ School of Earth and Environment, University of Leeds, Leeds LS2 9JT, United Kingdom

$\uparrow$ Corresponding author: petrash@ualberta.ca
} 
(OAE) (Schlanger and Jenkyns, 1976; Arthur and Schlanger, 1979; Arthur and others, 1990; Jenkyns, 2010).

Several episodes of oceanic anoxia that occurred between the Aptian $(\sim 125-113$ $\mathrm{Ma})$ and Albian $(\sim 113-100.5 \mathrm{Ma})$ have been collectively grouped within OAE 1 (Arthur and others, 1990). The OEA 1 was a period marked by the beginning of a greenhouse world, with rising sea level, warming global climate, and major turnovers in marine planktonic communities (for example, Bralower and others, 1994; Erbacher and others, 1996; Kuypers and others, 2002; Erba, 2004). Probably associated with this general warming were rapid dry/cool to wet/warm climate shifts that included short intervals of monsoonal precipitation which significantly augmented continental runoff (Arthur and others, 1990; Erbacher and others, 2001; Kuypers and others, 2001, 2002; Leckie and others, 2002; Herrle and others, 2003; Hay and others, 2006; Browning and Watkins, 2008; Mutterlose and others, 2009; Tejada and others, 2009; Barclay and others, 2010; Föllmi, 2012; Bottini and others, 2014; Bodin and others, 2015). The lithofacies resulting from OAE 1 not only include thick hemipelagic black shale intervals of economic importance due to their oil generation potential (Arthur and others, 1990; Wignall, 1994; Leckie and others, 2002), but also relatively thin organicrich shales of striking stratigraphic persistence and lateral continuity, interbedded with cyclic shallow marine carbonates (for example Ford and Houbolt, 1963; Fisher and Rodda, 1969; Bishop, 1975; Sass and Katz, 1982; Peterson, 1983; Patton and others, 1984; Halley, 1985; Sass and Bein, 1988; Claps and others, 1991; Bellanca and others, 1996, 1997; Lehmann and others, 1999; Bachmann and Hirsch, 2006; Gaona-Narvaez and others, 2013). Despite their widespread geographic distribution (see Westphal and Munnecke, 2003 for details), the driving forces controlling the cyclicity and early diagenesis of these intervals remains controversial. Theories range from orbital forcing mechanisms to differential microbial zonation, that is zonation of energy availability in the sediment pile (see Arthur and others, 1984; Hallam, 1986; Weedon, 1986; Weedon and Hallam, 1987; Raiswell, 1988; Westphal and Munnecke, 2003).

Within the shallow marine black shales, the presence of dolomite cement is quite common, and thus they have been referred to as dolomitic shales, argillaceous dolomites, and in some cases, dolomitic marlstones. The available sedimentological and geochemical evidence suggests that precipitation of interstitial dolomite could be related to low amplitude (high frequency) relative sea level changes superimposed on the generally transgressive state of the mid-Cretaceous seas (Given and Wilkinson, 1987; Sun, 1994; Erbacher and others, 1996, 2001; see also Haq and others, 1987). Moreover, the stratabound geometry of these rocks, and the petrographic relations between dolomite and other early diagenetic mineral phases, usually suggest that dolomite occurred penecontemporaneously, or shortly after deposition (Lehmann and others, 1999).

In this study, we explore the mechanisms that promoted dolomite precipitation in laterally continuous transgressive black shales in the Maracaibo Platform, northwestern South America (fig. 1). These Aptian to early Albian microfacies - now dolomitic marlstones - represent deposition in a shallow-marine, low energy, inner to middle ramp environment, affected by the episodic upwelling of $\mathrm{O}_{2}$-depleted, nutrient-rich basinal waters (Bartok and others, 1981; Renz, 1981, 1982; Vahrenkamp and others, 1993), and are likely related to the paleoceanographic perturbations associated with OAE 1 (Méndez-Dot and others, 2015). The almost continuous burial history of the epicontinental succession (Yurewick and others, 1998; Pöppelreiter and others, 2005), together with the differential compaction of argillaceous intervals comprising mixed carbonate-siliciclastic sequences (Bathurst, 1987; Dewers and Ortoleva, 1994), prevented the admixture of late diagenetic waters (see Bartok and others, 1981; Pöppelreiter and others, 2005), and thus allowed for the exceptional preservation of primary 


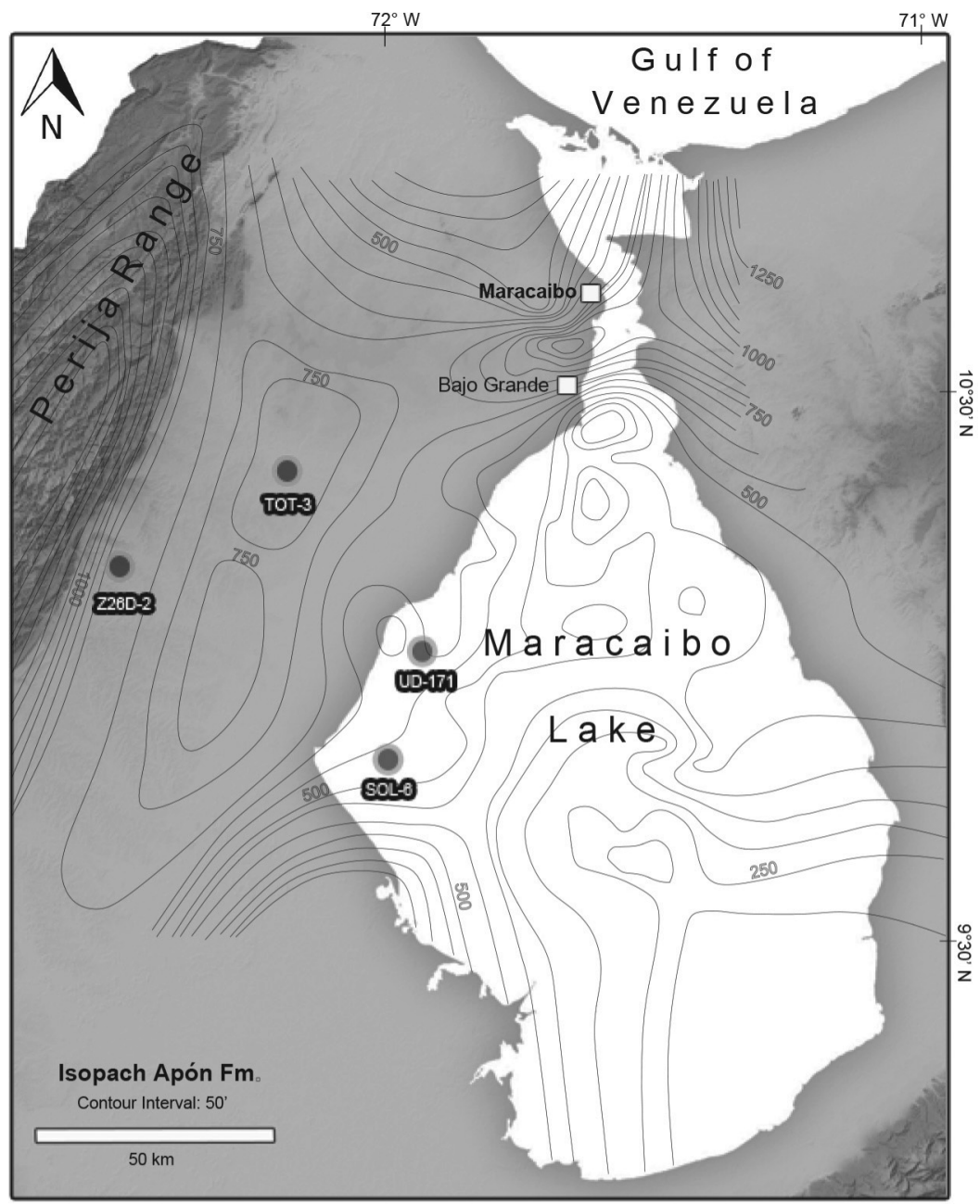

Dril cores
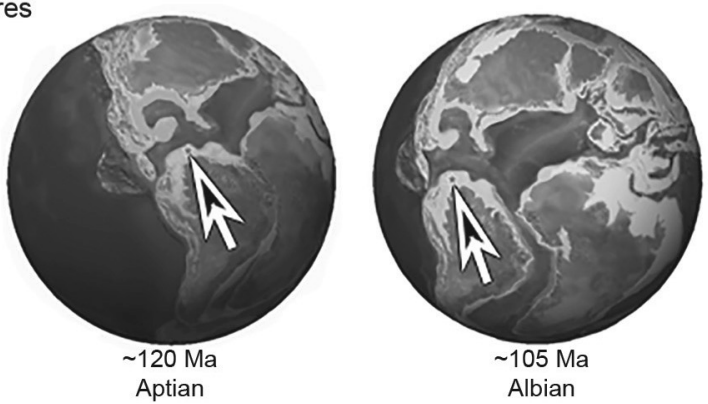

Fig. 1. Study area and location of the well cores. The contour intervals (isopach map) approximate the paleobathymetry at the time of deposition of the Apón Formation. The lower part of this figure shows the tropical paleogeographic location of the Maracaibo Platform during the Aptian to Albian transition (Paleogeography from: Colorado Plateau Geosystems, http://www2.nau.edu/rcb7, accessed July 2014). 


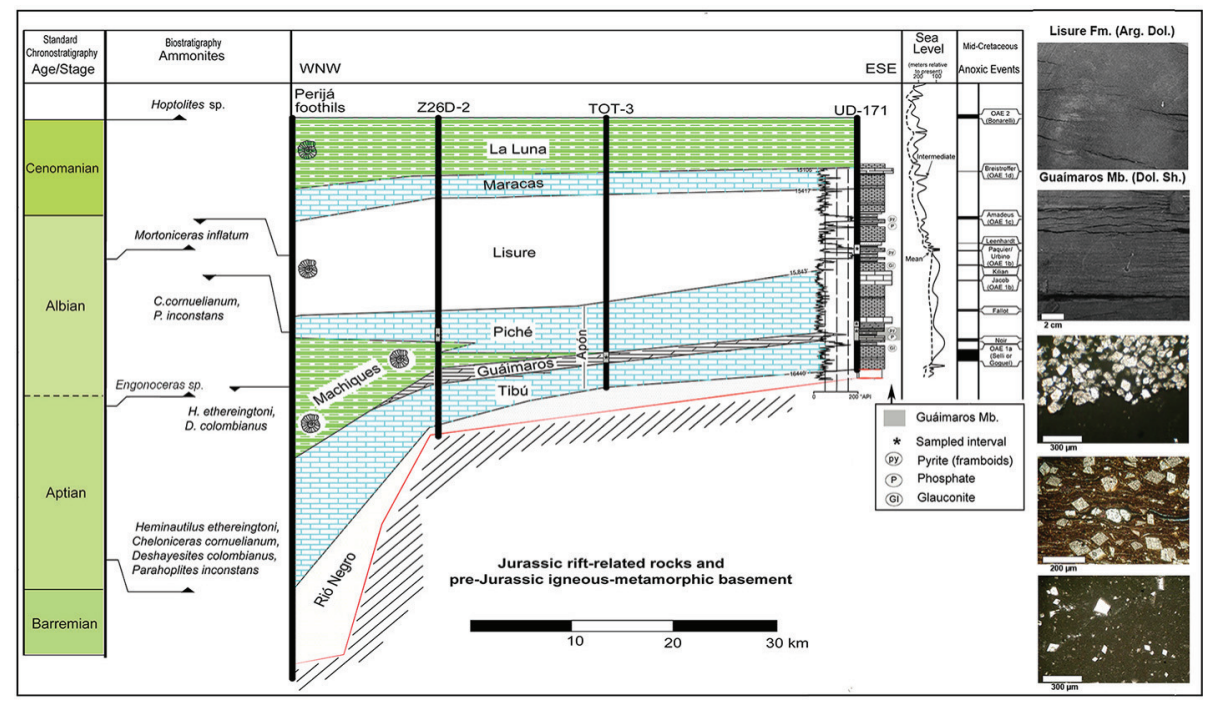

Fig. 2. The mid-Cretaceous stratigraphic context of western Venezuela. Samples are from four oil exploration drill cores. Ammonite zonation is as defined by Renz (1982) with data from a section outcropping at Santo Rosita Creek in the Perijá Foothills. Also shown are two representative core sections and the range of lithologies from dolomitic shale to argillaceous dolomite.

textural and geochemical features. Therefore, such intervals provide a unique opportunity to evaluate the timing of, and controls on, dolomite formation in mixed shallow marine depositional systems.

\section{GEOLOGICAL BACKGROUND}

The Aptian to early Albian in the subsurface of the Maracaibo lake area consists of a vertical succession of meter-scale, shallow marine carbonate deposits that exhibit systematic stacking patterns that build into three complex stratigraphic sequences (Vahrenkamp and others, 1993). Interbedded within shallow carbonates are laterally continuous, organic-rich, often pyritic, fine-grained laminar intervals (Ford and Houbolt, 1963; Bartok and others, 1981; Yurewicz and others, 1998). Lithostratigraphically, the Aptian to early Albian has been named as the Lower Cogollo Group, which in the subsurface of the Maracaibo Basin has been subdivided into three units: the lower (Tibú), middle (Machiques-Guáimaros) and upper (Piché) members of the Apón Formation (Renz, 1958).

Deposition of the basal lagoonal Tibú Member was followed, in the Perijá Range area, by a prominent interval (up to $120 \mathrm{~m}$ thick) of cyclic black shale - hemipelagic nodular floatstone couplets, known as the Machiques Member of the Apón Formation (see Alberdi-Genolet and Tocco, 1999). This member is areally restricted to the Machiques trough (after Sutton, 1946), a differentially subsiding post-rift sub-basin affected by Neogene inversion to form what is now the Perija Range (fig. 1). The Machiques Member has a well-preserved late Aptian ammonite fauna belonging to the genus Deshayesites sp., and toward the top contains Engonoceras sp., which spans the uppermost Aptian to the middle Albian interval (fig. 2; Renz, 1982).

Landwards, the Machiques Member encroaches onto a crinkled and laminar, 5 to 30-m-thick regional marker-bed referred to as the Guáimaros Member of the Apón Formation (Renz, 1958; Ford and Houbolt, 1963). This lithofacies can be recognized by being largely devoid of fauna, and by its dark gray to black color and laminar nature 
(Renz, 1958; Ford and Houbolt, 1963; González de Juana and others, 1980). Considering the timespan of the ammonite biozones on its distal equivalent (fig. 2), this member can be considered a condensed interval. The main mineralogical feature of the Guáimaros Shale is the abundance of dolomite and framboidal pyrite (Ford and Houbolt, 1963), and it may locally contain gypsum (González de Juana and others, 1980). The Guáimaros lithology is considered a regional marker bed, and has been thought to resemble modern marl sediments found in the Doha Lagoon in the Persian Gulf (Ford and Houbolt, 1963). Conversely, González de Juana and others (1980, p. 236) suggested that this interval may well represent deposition in an extended tidal flat.

Overlying the Guáimaros-Machiques members is the Piché Member of the Apón Formation, which also exhibits a mixed carbonate-siliciclastic peritidal to subtidal stacking pattern, and contains the first appearance of the Albian foraminifera, Orbitolina texana concava (Sutton, 1946; Renz, 1958). Early Albian ammonites may be present in the Piché Member (Renz, 1982), but most of its carbonate facies represent deposition in peritidal to shallow subtidal settings (Bartok and others, 1981).

By the time of the deposition of the Apón Formation, the accommodation space and facies architecture were largely controlled by the complex interplay between thermal subsidence and orbital forcing mechanisms, with differential subsidence controlling the development of paleobathymetric lows that were suitable for black shale deposition (Bartok, 1993; figs. 1 and 2). By producing minor shifts in base sea level and controlling paleoclimate, variations in the Earth's eccentricity and precession would have controlled the extension and distribution of shallow marine siliciclastic facies within the mixed carbonate-dominated ramp (see Vahrenkamp and others, 1993), and the cyclic deposition of black shales-floatstone couplets infilling the Machiques sub-basin (for example Alberdi-Genolet and Tocco, 1999). Additional information on the sequential context and environmental aspects pertaining the Lower Cogollo Group are available in the online supplementary material (http:// earth.geology.yale.edu/\% 7eajs/SupplementaryData/2016/Petrash.pdf).

On top of the Apón Formation is the $80 \mathrm{~m}$ thick Lisure Formation. The contact between the Apón and Lisure formations is thought to represent a depositional hiatus (Rod and Maync, 1954), and the unit is composed of a mixed carbonate-siliciclastic lithology, with some lithic sandstones. Toward its base, the formation contains microfacies similar to Guáimaros, but these are more limited in terms of their regional extent. Toward the top, the Lisure Formation contains abundant skeletal-oolitic grainstones that are often glauconitic (Renz, 1981), and are suggestive of an extended lagoonal subtidal environment (Bartok and others, 1981).

Overlying the Lisure Formation is the Maraca Formation, which consists of oncolithic floatstones that laterally grade to oolitic grainstones (Bartok and others, 1981).

SAMPLES

Our sampling focused on the laterally continuous dolomite-bearing Guáimaros Member. We also sampled analogous microfacies in the overlying lithological units (the early Albian Piché Mb. and the Lisure Fm.). Samples were retrieved from four exploration wells, most of which reached depths $>4 \mathrm{~km}$ in the subsurface of the Maracaibo lake area (figs. 1 and 2). The lateral distance between the studied boreholes ranges between 10 and $35 \mathrm{~km}$ (fig. 1). Borehole TOT-3 was drilled between 1928 and 1930. Borehole Z26D-2 was drilled in 1955, and boreholes UD-171 and SOL-6 were drilled between 1982 and 1984 .

The microfacies of interest are interbedded into peritidal cycles comprised of thick pelecypod floatstones, benthic foraminiferal (miliolids) wackestones, and mudstones, which frequently show crinkled lamination. Prior to sampling, the intervals of 
interest were first identified by using gamma ray and resistivity well logs, followed by a visual inspection of the cores and standard petrography of 235 thin sections. The samples from the upper stratigraphic levels have less lateral extent than the Guáimaros shale, which can be recognized across the study area (fig. 2). All of the representative samples $(\mathrm{n}=11 ; 9$ dolomitic black shale, that is, the marlstone, and 2 non-dolomitic black shale; fig. 2), were taken from the central part of drill cores $(150 \mathrm{~mm}$ in diameter). The sections of the cores sampled are not directly affected by faults and do not show evidence of post-depositional recrystallization or oxidation during storage.

ANALYTICAL METHODS

In order to investigate the early diagenetic conditions that governed mineral authigenesis of these intervals we applied a multi-analytical approach that combined an assessment of the microtextural relations between the solid phases, bulk geochemical characterization (biomarker signatures, minor and trace metals, and C-, O- and Sr-isotopes), and in situ synchrotron-based X-ray fluorescence microanalyses of dolomite. None of the parameters included in our comprehensive dataset follows a burial depth profile. Biomarker analyses followed rigorous protocols to exclude anthropogenic hydrocarbon contaminants that commonly taint drill core material (Jarrett and others, 2013). The robustness of our 'biomarker-derived' redox interpretations are further supported by iron speciation (Poulton and Canfield, 2005, 2011) and transition metal analyses, with the goal of interpreting the redox state of the water column and sediment pore water system at the time of deposition and during early diagenetic authigenesis. Details of the combined analytical approach are described in the online supplementary materials (http://earth.geology.yale.edu/\% 7eajs/SupplementaryData/ 2016/Petrash.pdf).

RESULTS AND DISCUSSION

\section{Petrology}

Standard petrography and weight dispersive spectrometric analyses revealed that the authigenic fraction of the microfacies under examination is dominated by Ca-rich dolomite, with minor framboidal pyrite and authigenic quartz (figs. 3A-3B). Scanning Electron Microscopy coupled to Energy Dispersive Spectrometry (SEM-EDS) revealed lesser amounts of gypsum, calcite, Ca-fluorapatite, and barite (figs. 3C-3G; Appendix A). All of the minerals listed above are within an organic-rich, detrital, clayey matrix, containing from 1.1 to 5.0 weight percent of total organic carbon (TOC). The sedimentary organic matter, as measured in samples from UD-171, has a $\delta^{13} \mathrm{C}_{\mathrm{org}}$ of $-22.5 \pm 1.7$ permil. Results of semi-quantitative XRD analysis of the $<2 \mu \mathrm{m}$ fraction showed the following mineralogy $( \pm 2 \%)$ : illite $(38 \%)$, kaolinite $(27 \%)$, and disordered illite/smectite clay (35\%); with illite accounting for up to 60 percent of that fraction. Further details on the mineral assemblage and its textural features are available in Appendix A.

In crystalline carbonate rocks (for example limestone/dolostone), the effects of late burial diagenesis often lead to multiple carbonate dissolution and re-precipitation stages that obliterate most of the primary textural features and chemical signals. However, in the late Aptian - early Albian dolomitic shale intervals studied here, the flow of thermally active diagenetic fluids was largely prevented by differential compaction, and thus the obliterating effects of carbonate recrystallization were greatly diminished. Therefore, inferences regarding the elusive mechanisms of penecontemporaneous dolomite stabilization could be drawn from our samples.

Interstitial dolomite is invariably associated with framboidal pyrite, and the lateral persistence of such textural relationship suggests that dolomite formed as a cement shortly after pyrite precipitation. Considering the intrinsic low permeability of the 

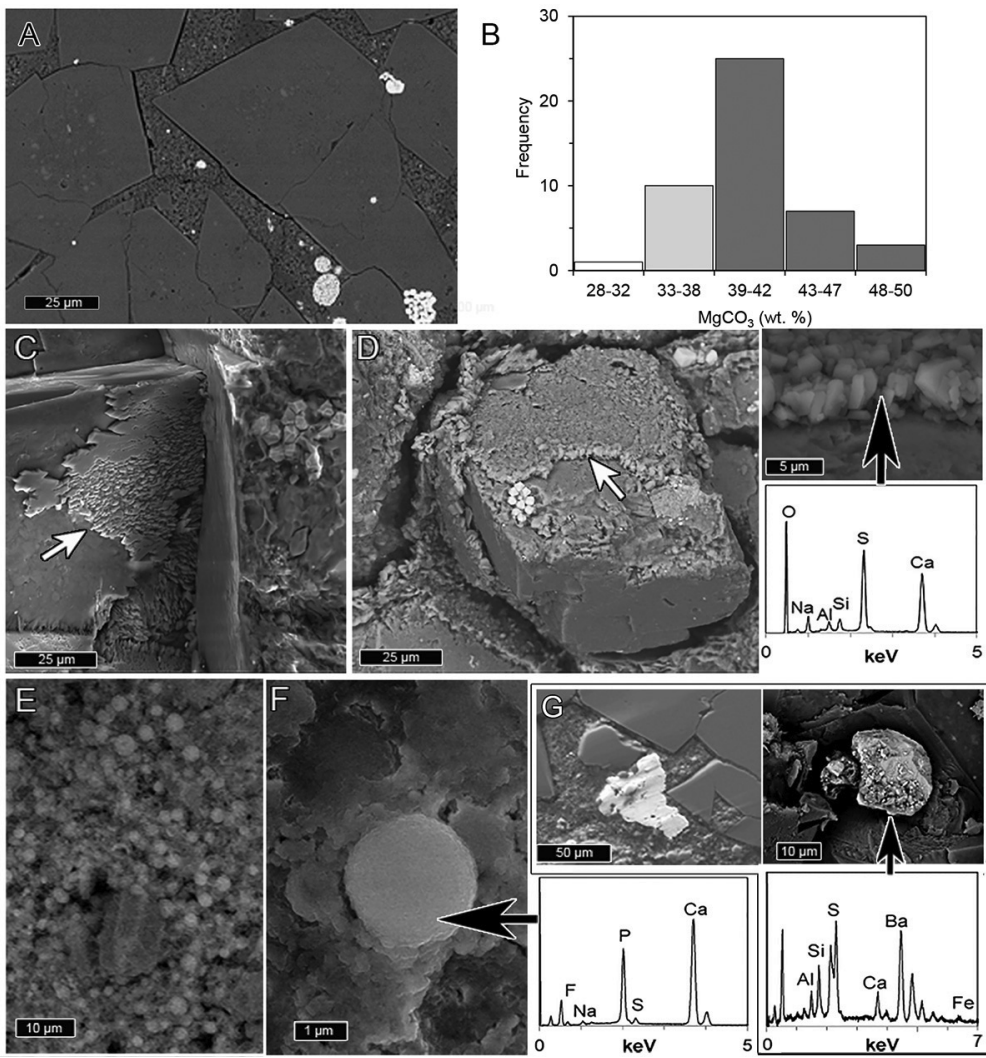

Fig. 3. Textural features: (A) Dolomite crystals interfaces range from planar-e to planar-s. Note the abundance of framboidal pyrite. (B) Most dolomite is Ca-enriched. (C-D) The dolomite crystals are coated by equant gypsum overlays that show planar interfaces caused by normal stress across the gypsum-clay contacts. (E-F) Cryptocrystalline Ca-fluorapatite is quite common within the matrix material. (G) Subordinate amounts of barite have been also observed.

targeted intervals (Bartok and others, 1981; Pöppelreiter and others, 2005) and the average size of the predominantly euhedral (planer-e) dolomite crystals $(\sim 80 \mu \mathrm{m})$, it is clear that most interstitial dolomite formation was completed prior to compaction. As interstitial dolomite grew, the crystals developed distinctive textural relations with pyrite, which may have been locally oxidized, leading to dissolution of metastable dolomite precursors followed by oversaturation of the pore waters with regard to Fe-dolomite that locally overgrew dolomite cortices. On the other hand, seasonality also operated to oversaturate the interstices of the sediments with regard to gypsum and/or silica, two minerals intimately associated with dolomite, thereby inhibiting further dolomite growth (Appendix A).

\section{Redox Conditions Governing Shallow Marine Black Shale Deposition}

Biomarkers are useful for the characterization of organic-rich lithofacies. The distribution of biomarkers may yield information about thermal maturity, biological sources of organic matter, activity of specific microorganisms (such as methanogens and methanotrophs), influx of terrestrial versus marine organic debris, and redox conditions (Brocks and Summons, 2004; Peters and others, 2005). Relevant biomarker ratios for Maracaibo samples are summarized in table 1, and the biological origins of 


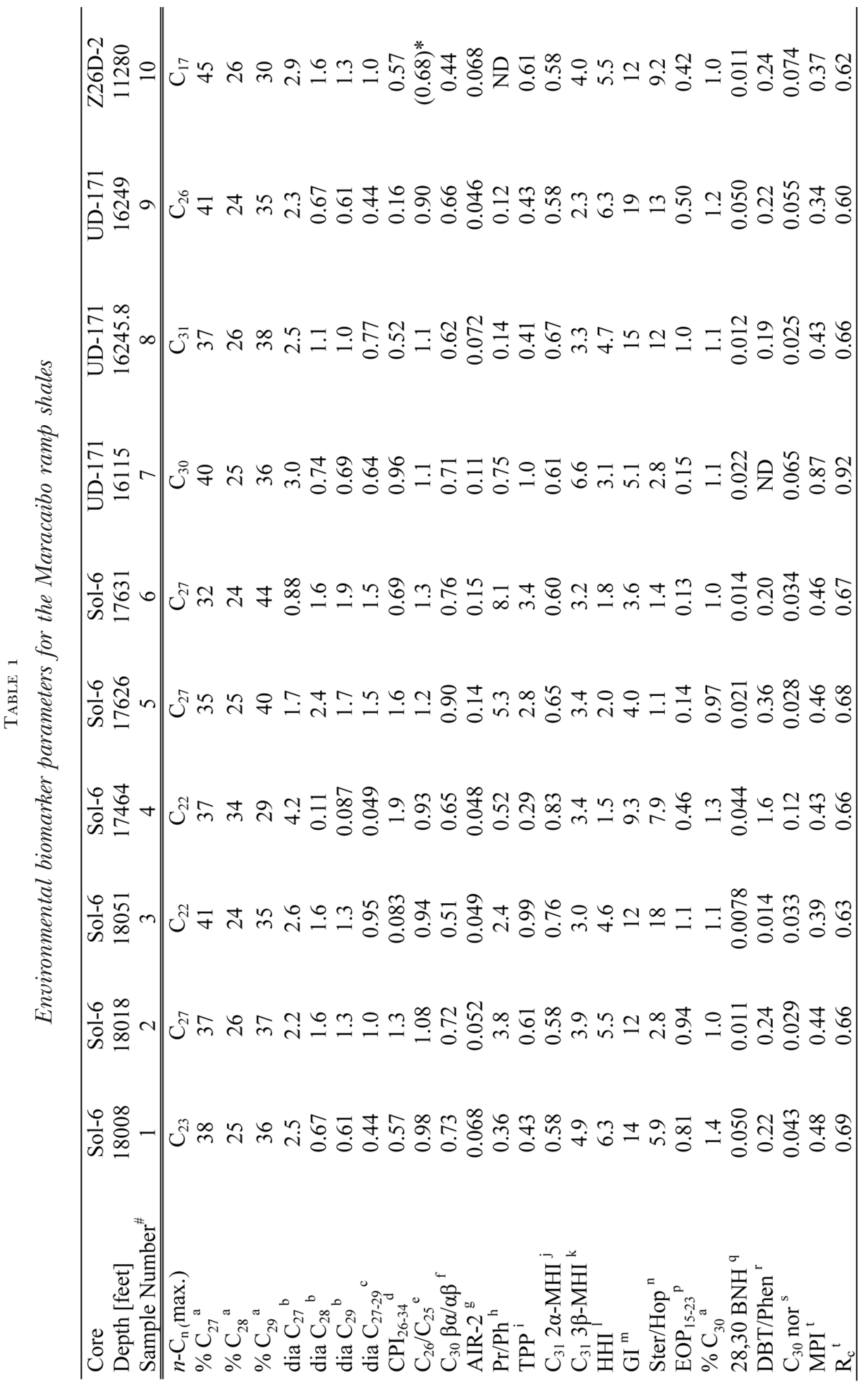




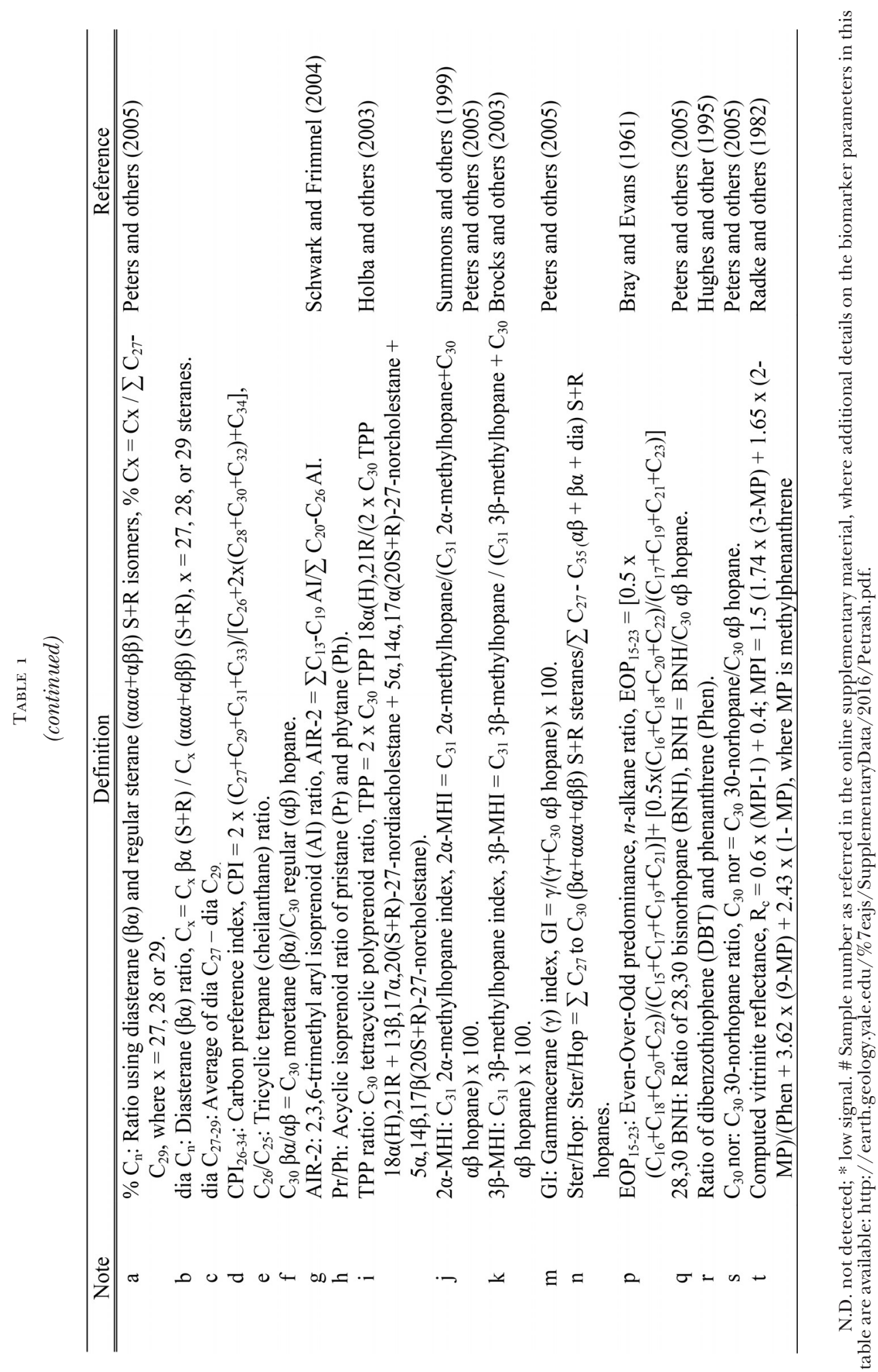


individual biomarkers, as well as a detailed interpretation of different parameters, are given in the online supplementary material (http://earth.geology.yale.edu/\% 7eajs/ SupplementaryData/2016/Petrash.pdf).

Several inorganic redox proxies (see below) and the biomarker parameters listed in table 1 show an unusual degree of intercorrelation. Furthermore, detailed analyses of redox sensitive biomarkers, in particular the fossil pigments of anoxygenic phototrophic bacteria and lipids of anaerobic ciliates (Appendix B), indicate that at the time of deposition of the studied intervals the Maracaibo ramp was likely anoxic into the photic zone of the water column. Possible correlations between geochemical parameters were assessed by applying a Principal Component Analysis (PCA) of scored data using XLStat 2014. The objective of PCA is to find unit-length linear combinations of the variables with the greatest variance. Because this study focuses on a specific microfacies, a stratigraphic analysis was not attempted. Instead, correlations of parameters between samples were assessed in order to determine environmental controls during organic matter deposition. Included in the PCA were the redox proxies $\mathrm{Fe}_{\mathrm{HR}} / \mathrm{Fe}_{\mathrm{T}}, \operatorname{Pr} / \mathrm{Pr}^{*}$ and $\mathrm{Mn}^{*}$, the terrestrial flux indicator $\mathrm{Al} /(\mathrm{Al}+\mathrm{Fe}+\mathrm{Mn})$, and the concentrations of certain elements, such as Mo and Hf, that could offer support to our interpretations. The biomarker parameters considered in the PCA are listed and explained in table 1, while the elemental/isotopic concentrations and ratios are listed in table 2.

Principal component analysis of redox proxies.-The first principal component, PC1, has maximal overall variance and explains 45 percent of the variance within the original data. The second principal component, PC2, has maximal variance amongst all unit length linear combinations that are uncorrelated to the first principal component, and explains 18 percent of the variance within the original data. Each subsequent PC describes the variance in progressively limited detail (for example PC3 $=14 \%$ ). The PC1 clusters the biomarker ratios and some inorganic redox proxies in two distinct categories, Categories I and II (fig. 4, see Appendix tables C1 and C2). Samples in both categories do not follow a burial depth profile, and most of them exhibit a normal distribution. None of the parameters are correlated with computed vitrinite reflectance, $R_{c}$ (table 1 ), ruling out maturity as a main component. Instead, Category I cluster parameters that reflect high relative input of terrestrial and lacustrine organic matter and soil, including $\mathrm{Al} /(\mathrm{Al}+\mathrm{Fe}+\mathrm{Mn}), \mathrm{C}_{29}$ steranes $\left(\% \mathrm{C}_{29}\right)$, plant waxes $\left(\mathrm{CPI}_{26-34}>\right.$ 1 ) and freshwater-derived algal markers (tetracyclic polyprenoids, TPP). Category I is also defined by a high oxidation level of organic matter, for example high aryl isoprenoid cleavage (AIR-2), high pristane $\left(\mathrm{Pr}, \mathrm{C}_{19}\right)$ to phytane $\left(\mathrm{Ph}, \mathrm{C}_{20}\right)$ ratios $(\mathrm{Pr} / \mathrm{Ph})$, and by clay-induced molecular rearrangements $\left(\operatorname{diaC}_{27}-\mathrm{C}_{30}, \mathrm{C}_{30} \beta \alpha / \alpha \beta\right)$ (Appendix table $\mathrm{C} 1$ ). All parameters in Category I point to a terrestrial organic matter and detrital source that is elevated biomarkers of terrestrial and lacustrine origin, significant oxidation of organic matter as expected from redeposited soil, as well as abundant clay availability. Among the 31-dimensions considered in our PCA are parameters that can be unequivocally associated with detrital aluminosilicates, such as bulk-rock Hf concentrations, and parameters that are known to be affected by the influx of detritus, such as La anomalies $(\mathrm{Ce} / \mathrm{Ce} *)_{\mathrm{SN}}$ and $\mathrm{V} /(\mathrm{V}+\mathrm{Ni})$. These parameters fall within Category I (fig. 4).

In contrast, biomarker values in Category II (Appendix table C2) are typical for organic matter of marine origin, such as high $\mathrm{C}_{27}$ and $\mathrm{C}_{30}$ sterane proportions $\left(\% \mathrm{C}_{27}\right.$, $\left.\% \mathrm{C}_{30}\right)$, high sterane versus hopane ratios (Ster/Hop), high relative gammacerane abundances (high GI) and $\mathrm{EOP}_{15-23}$ (fig. 4; see also table 1). It is not clear whether $28,30 \mathrm{BNH}$ can be included in our Category II, although it exhibits significant correlation with $2 \alpha-\mathrm{MHI}(\mathrm{Rs}=0.74,0.05 P>0.01$ ), which is likely to be produced by nitrogen-fixing organisms thriving under low oxygen levels (Ricci and others, 2013). Moreover, Category II also include the dibenzothiophene (DBT): phenanthrene 


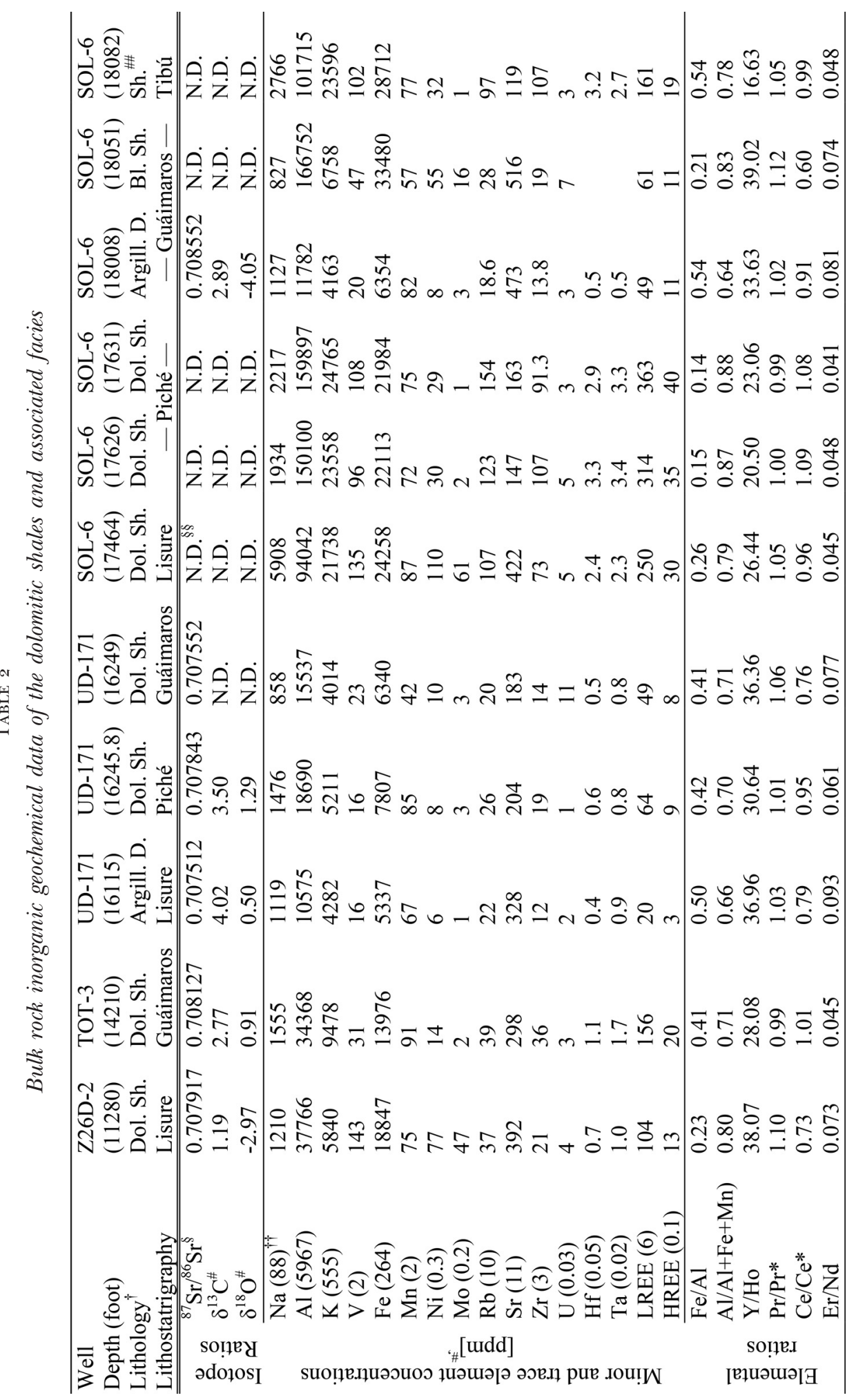




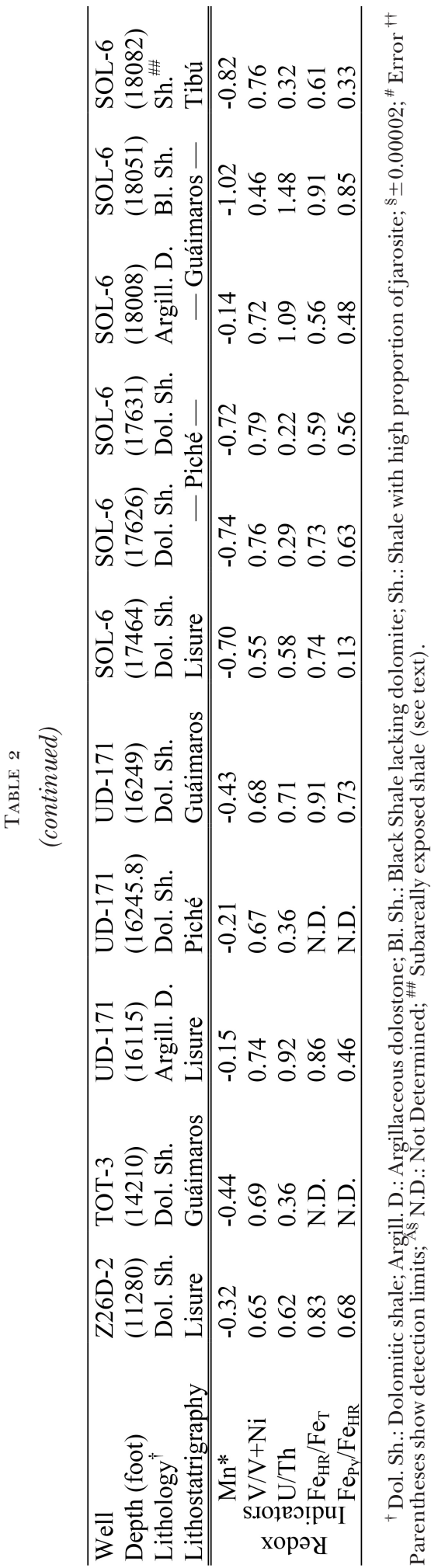




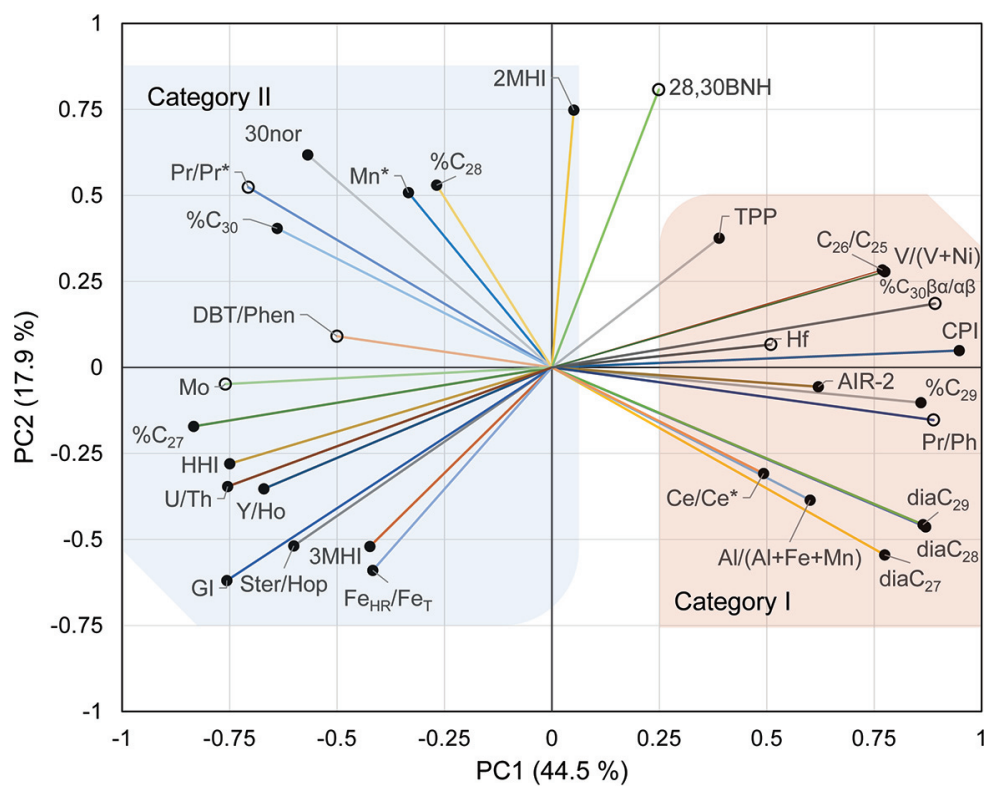

Fig. 4. PCA of environmental proxies determined for samples from the Maracaibo ramp. Filled markers exhibit a normal distribution. The risk of considering unfilled markers as normally distributed is in all cases less than $3.8 \%(\alpha=0.05 \%)$, and the incorporation of these parameters in the n-dimensional dataset does not significantly alter the clustering.

(Phen) ratio, which can be used to gauge the availability of free sulfur in the depositional environment, and thus offers possible evidence for anoxic depositional conditions. The clustering of homohopane indices (HHI), manganese and molybdenum enrichments, as well as an accumulation of highly reactive iron $\left(\mathrm{Fe}_{\mathrm{HR}} / \mathrm{Fe}_{\mathrm{T}}\right)$ indicate a stable anoxic water column. The latter parameters are considered as robust redox indicators. In sediments deposited beneath anoxic waters, the $\mathrm{Fe}_{\mathrm{HR}} / \mathrm{Fe}_{\mathrm{T}}$ ratios are typically above 0.38 (Raiswell and Canfield, 1998; Raiswell and others, 2001; Poulton and Raiswell, 2002; Poulton and Canfield, 2011). All of our $\mathrm{Fe}_{\mathrm{HR}} / \mathrm{Fe}_{\mathrm{T}}$ ratios are consistently greater than 0.50 (fig. $5 \mathrm{~A}$, table 2 ). Other inorganic parameters falling into Category II include redox proxies such as $\mathrm{U} / \mathrm{Th}$ and $\mathrm{Mn} *\left(\mathrm{Mn} *=\log \left[\left(\mathrm{Mn}_{\text {sample }}\right)\right.\right.$ $\left.\left.\mathrm{Mn}_{\text {shale }}\right) \cdot\left(\mathrm{Fe}_{\text {sample }} / \mathrm{Fe}_{\text {shale }}\right)^{-1}\right]$; Machhour and others, 1994). In summary, the clustering in our PCA is clearly controlled by varying influx of oxidized terrestrial and lacustrine organic matter into a stratified and reducing marine depositional environment. The results point to variations in terrestrial run-off as a control on the transport of oxidized soil material into an anoxic shallow marine depositional setting.

Transient photic zone euxinia.-The redox chemistry during deposition of the marlstones was also examined by determining the extent to which the $\mathrm{Fe}_{\mathrm{HR}}$ pool was pyritized $\left(\mathrm{Fe}_{\mathrm{Py}} / \mathrm{Fe}_{\mathrm{HR}}\right)$. This ratio distinguishes whether the ramp was euxinic (that is sulfide-rich) or ferruginous (Fe-rich), with $\mathrm{Fe}_{\mathrm{Py}} / \mathrm{Fe}_{\mathrm{HR}} \sim 0.70$ differentiating euxinic from ferruginous $(\leq 0.70)$ conditions (Poulton and Canfield, 2011). The $\mathrm{Fe}_{\mathrm{Py}} / \mathrm{Fe}_{\mathrm{HR}}$ values of the dolomitic marlstones are consistent with deposition under a predominantly ferruginous water column, with a couple of samples reflecting the development of transient euxinic conditions (fig. $5 \mathrm{~A}$ ). The $\mathrm{Fe}_{\mathrm{Py}} / \mathrm{Fe}_{\mathrm{HR}}$ together with the ubiquity of relatively large pyrite framboids in the microfacies targeted here (see Appendix A) indicates that most pyrite precipitated in a transient euxinic-ferruginous chemocline located at or below the sediment-water interface as compared with a chemocline in the 

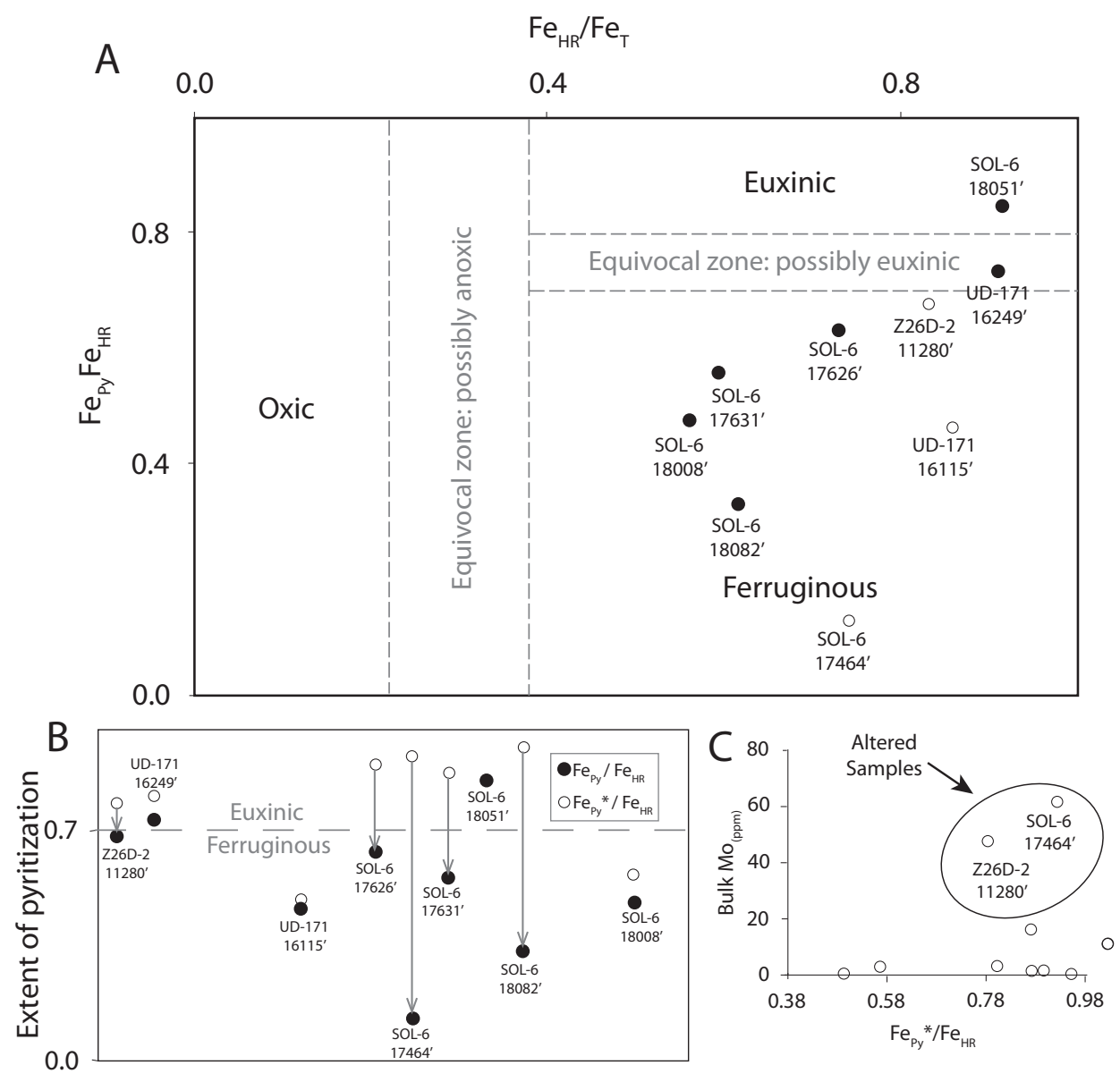

Fig. 5. Iron speciation data and Mo concentration data: (A) Highly reactive iron to total iron ratios $\left(\mathrm{Fe}_{\mathrm{HR}} / \mathrm{Fe}_{\mathrm{T}}\right)$ vs. the extent to which the $\mathrm{Fe}$ pool has been pyritized $\left(\mathrm{Fe}_{\mathrm{Py}} / \mathrm{Fe}_{\mathrm{HR}}\right)$. Our data shows that the Guáimaros Member and its upper analogues were dominantly deposited under anoxic (ferruginous) water columns, but the upwelling of euxinic mid-depth waters would have readily titrated Fe(II) as pyrite. (B) An alteration test (see text for details) suggests that samples exhibiting a $\mathrm{Fe}_{\mathrm{py}}{ }^{*}$ above 0.7 may be reflective of subaerial alteration. This indicates that the formation of $\mathrm{Fe}_{\mathrm{Ox}}$ from the oxidation of pyrite would have affected the original $\mathrm{Fe}_{\mathrm{Py}} / \mathrm{Fe}_{\mathrm{HR}}$ to make appear initially euxinic samples as ferruginous (C). Only samples exhibiting relatively high [Mo] are considered as altered by pyrite oxidation, and potentially deposited under euxinic conditions.

water column, which is thought to produce framboids of less than $6 \mu \mathrm{m}$ in diameter (Wilkin and others, 1996; Wignall and Newton, 1998). Thus, in the studied intervals now dolomitic marlstones - most pyrite crystal growth occurred in the sediments and was likely limited by the supply of HS' near the sediment-water interface (see Berner, 1984; Butler and Rickard, 2000; Rickard, 2012 for details). A bimodal size distribution of pyrite in our samples (Appendix A) could be explained by the transport of small pyrite aggregates formed in the outer ramp to the inner ramp setting represented by our samples.

\section{Timing and Conditions of Dolomite Precipitation}

Timing of precipitation.-The bulk strontium concentrations of the dolomitic marlstones range from 143 to $744 \mathrm{ppm}$ (table 2). The samples exhibit ${ }^{87} \mathrm{Sr} /{ }^{86} \mathrm{Sr}$ values 

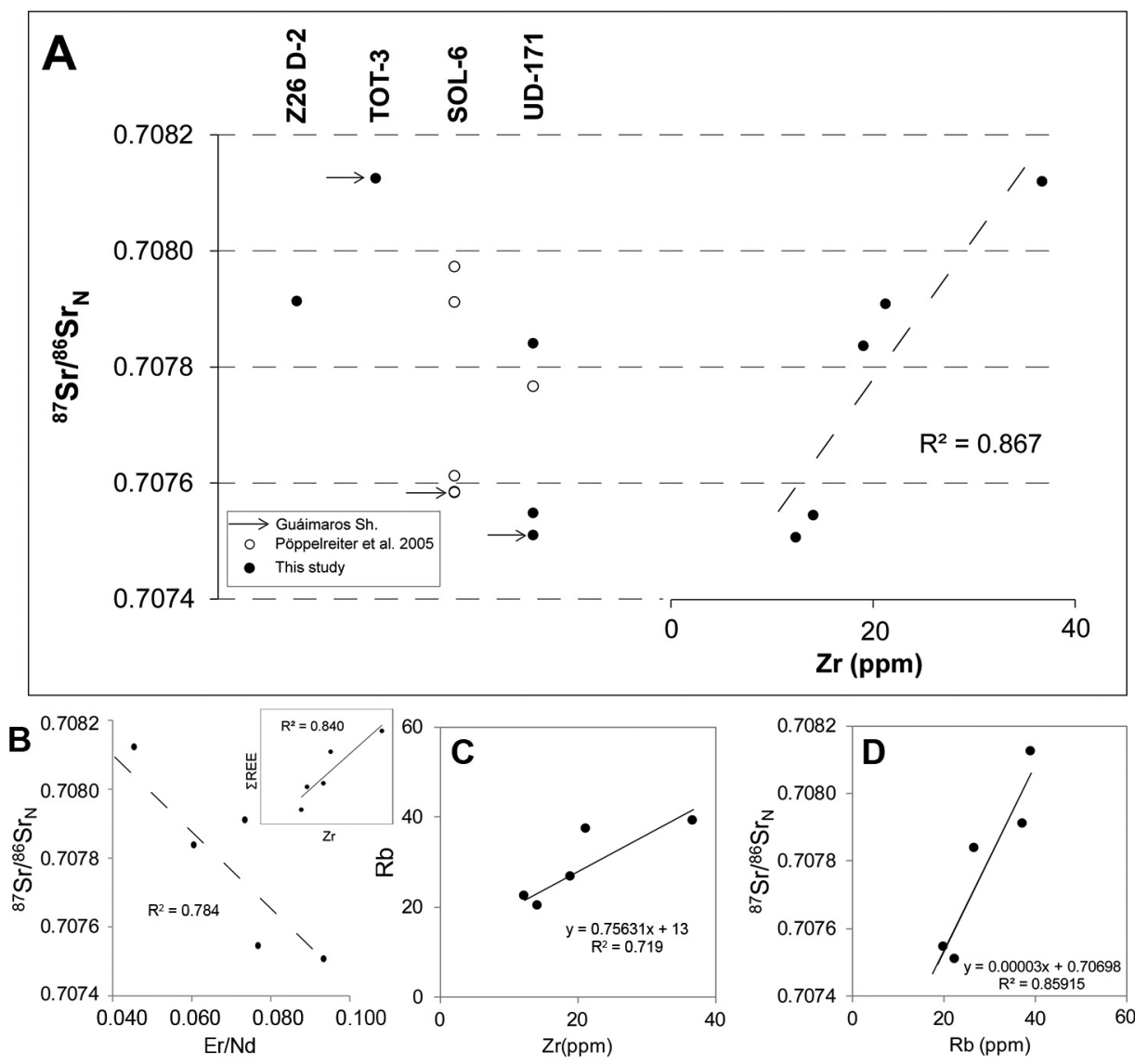

Fig. 6. Strontium ${ }^{87} \mathrm{Sr} /{ }^{86} \mathrm{Sr}$ values range from 0.70751 to 0.70812 , with higher values observed toward the Perijá Range: (A) There is a strong correlation between bulk rock [Zr] and the Sr-isotope signatures of the samples. The open circles represent samples studied by Pöppelreiter and others (2005); the filled circles represent the dolomitic shales targeted in this study. (B) The HREE/ LREE ratio of the samples (estimated by using their PAAS-normalized Er/Nd ratio) and the bulk concentrations of elements such, as $\mathrm{Zr}$, and $\mathrm{K}$ (not shown), were found to be strongly correlated with the measured ${ }^{87} \mathrm{Sr} /{ }^{86} \mathrm{Sr}_{\mathrm{N}}$ values. The inset shows that there is also a strong correlation between $\Sigma$ REEs and $\mathrm{Zr}$, which account for the detrital nature of the observed Sr-isotope trends. (C) Binary plots of Rb vs. Zr and (D) ${ }^{87} \mathrm{Sr} /{ }^{86} \mathrm{Sr}_{\mathrm{N}}$ vs. Rb. A: Rb vs. Zr content. This test of isotopic integrity is to establish whether initial isotope ratios correlate with trace element systematics (see Kamber and others, 2004 for details).

from 0.70751 to 0.70812 (fig. $6 \mathrm{~A}$; table 2), and are thus enriched in ${ }^{87} \mathrm{Sr}$ with respect to the signatures typically observed in biogenic allochems formed in equilibrium with late Aptian to early Albian seawater ( 0.70735; see McArthur and others, 2007).

The ratio of bulk rock heavy vs. light rare earths contents $(\mathrm{Er} / \mathrm{Nd})$ and the measured ${ }^{87} \mathrm{Sr} /{ }^{86} \mathrm{Sr}$ values were found to be correlated (fig. 6B) with the bulk concentrations of $\mathrm{Zr}\left(\mathrm{R}_{\mathrm{S}}=1.00,0.01>P>0.005\right)$ and $\mathrm{K}\left(\mathrm{R}_{\mathrm{S}}=0.90,0.050>P>\right.$ $0.025)$. The high degree of correlation indicates that the observed shift of ${ }^{87} \mathrm{Sr} /{ }^{86} \mathrm{Sr}$ isotope ratio toward more heavy values probably reflect variable rates of interaction of early diagenetic pore fluids with seawater containing a radiogenic Sr signature. Such a radiogenic signature was likely derived from the Triassic granitic and Jurassic arkosic sources in the hinterlands, which had initial values between 0.715 and 0.708 , respectively (Maze, 1984). 

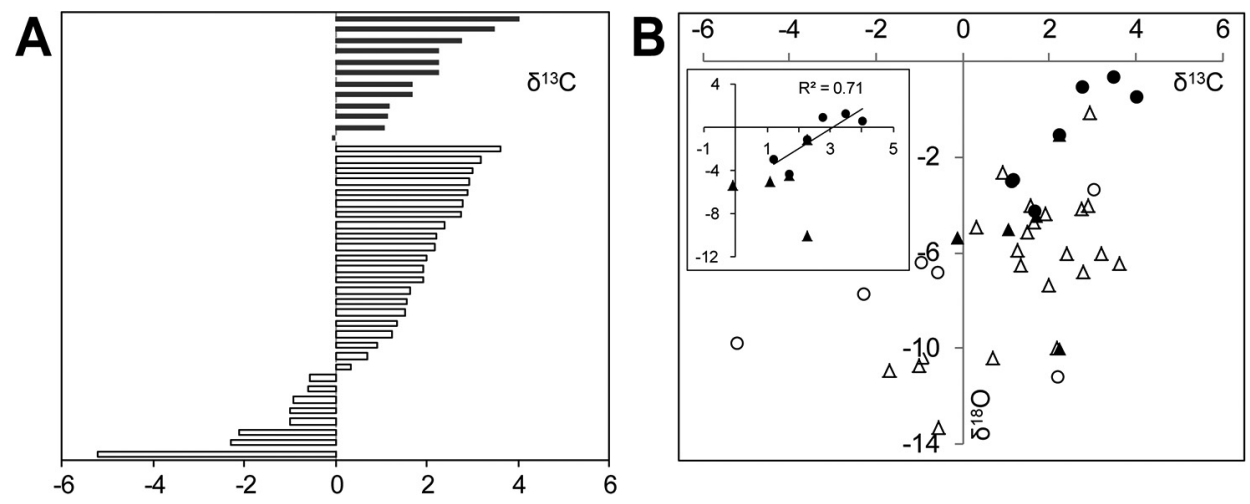

Fig. 7. Stable $\mathrm{C}$ and $\mathrm{O}$ isotope signatures of the carbonate cements: (A) Compiled carbonate C-isotope data from the Apón Formation (open bars) show a wider dispersion of $\delta^{13} \mathrm{C}$ isotope values than values measured in our samples. Carbonates in the microfacies studied here (filled bars) reflect a more significant contribution of marine-derived DIC. (B) The binary plot shows $\delta^{13} \mathrm{C}$ vs. $\delta^{18} \mathrm{O}$ values of in the Apón Formation. Calcite coexisting with dolomite in calcified dolostones (triangles) and dolomitic shales (circles) shows ${ }^{18} \mathrm{O}$ depletion (about $5 \%$ ). Filled data points are data from the Guáimaros Shale.

Following Kamber and others (2004), we further evaluated the correlation of ${ }^{87} \mathrm{Sr} /{ }^{86} \mathrm{Sr}$ ratios and the bulk-Rb concentrations of the samples $\left(\mathrm{R}_{\mathrm{S}}=0.90,0.050>P>\right.$ $0.025)$. The significant correlation between $\mathrm{Rb}$ and $\mathrm{Zr}$ contents makes it possible to estimate the $\mathrm{Rb}$ content of a hypothetical sample uncontaminated with radiogenic $\mathrm{Sr}$ (that is $\mathrm{Zr}<\mathrm{D} . \mathrm{L}$ ), in this case yielding approximately $13 \mathrm{ppm} \mathrm{Rb}$ (fig. 6B). Again, following the reasoning of Kamber and others (2004), this [Rb] can be extrapolated along a Sr-isotope vs. $\mathrm{Rb}$ concentration plot to yield an initial ${ }^{87} \mathrm{Sr} /{ }^{86} \mathrm{Sr}$ ratio of $\sim 0.70738$ (fig. 6C). This value corresponds to the late Aptian-early Albian ${ }^{87} \mathrm{Sr} /{ }^{86} \mathrm{Sr}$ seawater curve (Bralower and others, 1997; McArthur and others, 2001, Bodin and others, 2015). The time of precipitation deduced from combining the radiogenic $\mathrm{Sr}$ isotope and trace metal results are consistent with the measured $\delta^{13} \mathrm{C}$ of our samples, which range from +1.2 to $+4.0 \%$ (median +2.5 ; mean $+2.4 \%$ ) , and thus seems to reflect a significant seawater-derived dissolved inorganic carbon source, which by the time of precipitation was approximately $+2.5 \pm 1.0 \%$ (Menegatti and others, 1998).

Figure 7 shows a compilation of previously reported bulk ${ }^{13} \mathrm{C}$ values of dolostones in the Apón Formation together with values determined in this study. While published data for the $\delta^{13} \mathrm{C}$ of dolomites in the Apón Formation ranges from -5.2 to $+4.0 \%$ o (V-PDB), within our dolomitic marlstones the $\delta^{13} \mathrm{C}$ values fall within the positive range. More negative $\delta^{13} \mathrm{C}$ values were observed by Pöppelreiter and others (2005) in fabric destructive dolostones with good reservoir properties, but such microfacies were not considered in this study because we focused on dolomitic black shales. When calcite is present (see Appendix A), its $\delta^{13} \mathrm{C}$ ranges from -0.1 to $+2.3 \%$ (fig. $7 \mathrm{~B}$ ). The sedimentary organic matter as measured in samples from UD-171 has a $\delta^{13} \mathrm{C}_{\text {org }}$ of $-22.5 \pm 1 \%$.

The oxygen isotopes of the samples averaged -1.2 permil, and largely follow the trend in carbon isotopes (table 2; fig. 7B). This correlation is suggestive of a primary kinetic fractionation, and would have resulted from the influence of sporadic wet periods (Craig and others, 1963; Marshall, 1992; Zeebe and Wolf-Gladrow, 2001). However, interpretations resulting from correlated $\delta^{13} \mathrm{C}$ and $\delta^{18} \mathrm{O}$ values are often ambiguous (for example Knauth and Kennedy, 2009). Interestingly, calcite, when present (see Appendix A), reaches $\delta^{18} \mathrm{O}$ values as low as $-10.1 \%$ V-PDB (average $-5 \% 0$ ) and is uncorrelated with the measured $\mathrm{C}$-isotope values. For all of the available 
oxygen isotope data, the magnitude of the ${ }^{18} \mathrm{O}$ depletion on calcite is about 5.6 permil lower than dolomite. This difference compares fairly well with values expected for equilibrium paired phases (O’Neil and Epstein, 1966).

Redox precipitation environment. - The iron speciation data and other redox sensitive parameters for Category II in the PCA provide good evidence for anoxic (largely ferruginous) and redox stratified depositional conditions. The combined dataset indicates that the shallow water column in the ramp at the time of deposition remained permanently redox stratified and there was no regular flux of oxygenated waters to the sediment-water interface. The bulk and intracrystalline Mo concentrations of the samples (table 2 and Appendix table A1) are consistent with our iron speciation dataset, and point to alternating ferruginous and euxinic early diagenetic redox conditions during the deposition and alteration of the black shales to dolomitic marlstones.

From the correlation of the elemental ratios described above, it is clear that samples characterized by a larger terrigenous supply also exhibit more negative $\mathrm{Mn}^{*}$ values, pointing to increased redox potentials at times of increased terrigenous fluxes to the ramp (for example Bellanca and others, 1997). In this regard, the intracrystalline correlation between $\mathrm{Mn} *$ and the $\mathrm{Er} / \mathrm{Nd}$ is also significant $\left(\mathrm{R}_{\mathrm{s}}=0.80,0.01>P>\right.$ 0.005). Such a correlation trend, first observed by Bellanca and others (1996), would have resulted from the characteristic complexation behavior of REEs and metal (oxy) hydroxides (Davranche and others, 2008; Schijf and Marshall, 2011).

To summarize, the analysis of the covariance of organic and inorganic redox parameters showed that $\mathrm{Mn}$ (IV) and $\mathrm{Fe}$ (III) reduction were important processes at the time of dolomite precipitation. Our spatially resolved semi-quantitative XRF analysis, on the other hand, shows a limited range of intracrystalline variability in the iron and manganese signals (see below), which we interpret as the result of interstitial dolomite precipitation under a relatively constant Eh regime. Locally, post-depositional pyrite oxidation may have affected the original $\mathrm{Fe}_{\mathrm{Py}}$ content of those samples that exhibit iron enriched dolomite overgrowths (Appendix A).

Terrigenous influx and changes in salinity.-As observed in other tropical and subtropical mid-Cretaceous sequences (Lehmann, and others, 1999; Herrle and others, 2004; Browning and Watkins, 2008), monsoonal forcing mechanisms would have led to a transient influx of freshwater and finer-grained detritus to the inner ramp. This caused the development of a schizohaline environment (Folk and Siedlecka, 1974). Such environmental conditions, considered to be favorable to dolomite precipitation (Mazzullo and Friedman, 1977), are supported by the intracrystalline La anomaly $\left(\mathrm{Ce} / \mathrm{Ce}^{*}\right)$ of dolomite, which ranges from 0.5 to 1.0 (mean: 0.7; median: 0.8; table 2) and points to a precipitation environment in which the influx of freshwater tended to dissolve the marine-derived La signal. This interpretation is confirmed by the bulk rock correlation between $\mathrm{Y} / \mathrm{Ho}$ and $\mathrm{Ce} / \mathrm{Ce}^{*}\left(\mathrm{R}_{\mathrm{s}}=-0.89, P>0.001\right)$, which indicates some dilution of the marine $\mathrm{Y} / \mathrm{Ho}$ signal (for example Bolhar and Van Kranendonk, 2007).

Despite strong geochemical evidence supporting salinity changes at the time of dolomite precipitation, most of our redox and detritus sensitive parameters support that the schizohaline precipitation environment remained redox stratified, and the oxygen isotope content (table 2) and intracrystalline sodium concentrations of the samples (Appendix table A1) point to predominantly hypersaline conditions (for example Major and others, 1992; Staudt and others, 1993, respectively). The presence of gypsum as a minor authigenic component (Appendix A), and as small lenses in outcrops of the Guáimaros Shale in the foothills of the Mérida Andes (González de Juana and others, 1980), would appear to reflect an evaporitic condition locally prevailing in the inner ramp early after the onset of dolomite precipitation. To explain 
the textural relation between dolomite and microcrystalline equant gypsum (figs. 3C-3D) two non-mutually exclusive scenarios are envisioned: (1) washover events that led to dissolution of subaerial exposures of gypsum precipitated within supratidal sediments, and/or (2) the oxidation of abundant framboidal pyrite within exposed fine-grained sediments. The local presence of jarosite and cobaltarhurite within a non-dolomitic shale level — analyzed for comparison purposes (SOL-6 18 082') — might best be explained by local subaerial exposure conditions of the fine-grained pyritic sediments.

The inorganic observations are consistent with our biomarker dataset, which include a diverse range of concentrations of $n$-alkanes, acyclic isoprenoids, hopane and sterane ratios (table 1) that point to a predominance of evaporitic conditions (see Schinteie and Brocks, 2014). Additional information on these biomarkers is available in the online supplementary materials (http://earth.geology.yale.edu/\%7eajs/ SupplementaryData/2016/Petrash.pdf).

\section{Sensitivity of Results to Diagenetic Modification}

The biomarker ratios DBT/Phen, $\mathrm{Pr} / \mathrm{Ph}, \mathrm{HHI}$ and AIR-2 (table 1), as well as the iron speciation parameters $\mathrm{Fe}_{\mathrm{HR}} / \mathrm{Fe}_{\mathrm{T}}$ and $\mathrm{Fe}_{\mathrm{Py}} / \mathrm{Fe}_{\mathrm{HR}}$ provide a measure of the $\mathrm{Eh}$ regime. In principle, each of these parameters may be affected by late diagenetic or maturity-related processes, or even oxidation and contamination during storage of the drill core material. However, AIR-2 correlates positively with $\mathrm{Ce} / \mathrm{Ce} *\left(\mathrm{R}_{\mathrm{S}}=0.80\right.$, $0.05>P>0.01)$ and negatively with $\mathrm{HHI}\left(\mathrm{R}_{\mathrm{S}}=-0.83, P<0.01\right)$ and $\mathrm{Fe}_{\mathrm{HR}} / \mathrm{Fe}_{\mathrm{T}}\left(\mathrm{R}_{\mathrm{S}}=\right.$ $-0.40,0.5>P>0.1)$, suggesting that the redox signals are largely primary. Interestingly, the extent of pyritization of highly reactive iron $\left(\mathrm{Fe}_{\mathrm{Py}} / \mathrm{Fe}_{\mathrm{T}}\right)$ does not correlate significantly with any parameter clustering in our PCA Category I, suggesting that pyritization was not influenced by the influx of terrestrial debris (see below).

Pyrite oxidation may have affected the original Fe speciation values, such that initially euxinic sediments now produce a ferruginous signal (that is they now exhibit relatively low $\mathrm{Fe}_{\mathrm{Py}} / \mathrm{Fe}_{\mathrm{HR}}$ ). To address this potential alteration issue, we applied a test that assumes - as an end member scenario - that all of the oxidized $\mathrm{Fe}_{\mathrm{HR}}$ phases (that is $\mathrm{Fe}_{\mathrm{Ox}}$ ) were derived from pyrite oxidation. Since iron is conservative through transformation of $\mathrm{Fe}_{\mathrm{Py}}$ to $\mathrm{Fe}_{\mathrm{Ox}}$, and pyrite oxidation should not result in any significant change in $\mathrm{Fe}_{\mathrm{HR}} / \mathrm{Fe}_{\mathrm{T}}$, we recalculated the extent of pyritization by producing a $\mathrm{Fe}_{\mathrm{Py}}{ }^{*} / \mathrm{Fe}_{\mathrm{HR}}$ ratio, where $\mathrm{Fe}_{\mathrm{Py}}{ }^{*}=\mathrm{Fe}_{\mathrm{Py}}+\mathrm{Fe}_{\mathrm{Ox}}$. Accordingly, when a sample exhibiting relatively low $\mathrm{Fe}_{\mathrm{Py}} / \mathrm{Fe}_{\mathrm{HR}}$ has $\mathrm{Fe}_{\mathrm{Py}}{ }^{*} / \mathrm{Fe}_{\mathrm{HR}}>0.70$, then that sample may have been oxidized, whereas if the $\mathrm{Fe}_{\mathrm{Py}} * / \mathrm{Fe}_{\mathrm{HR}}$ ratio remains below the 0.70 threshold, then the sample was indisputably deposited under a ferruginous water column. As shown in figure $5 \mathrm{~B}$, our alteration test indicates that some samples may have been deposited under the influence of euxinic waters. However, since this test assumes the extreme case that all $\mathrm{Fe}_{\mathrm{Ox}}$ derives from pyrite oxidation (when, in fact, there was likely some $\mathrm{Fe}_{\mathrm{Ox}}$ in the pre-oxidized sample), and oxidation of $\mathrm{Fe}(\mathrm{II})$ in carbonate minerals would also generate $\mathrm{Fe}_{\mathrm{Ox}}$, additional evidence must be sought.

To evaluate the potential for more prevalent euxinic depositional conditions across the ramp, we assessed the concentrations of the redox-sensitive element molybdenum, which is specifically drawn down into the sediment under euxinic water column conditions (Helz and others, 1996; Zheng and others, 2000; Barling and others, 2001; Nägler and others, 2005) (fig. 5B; see also table 2). In addition to two samples that have original $\mathrm{Fe}_{\mathrm{Py}} / \mathrm{Fe}_{\mathrm{HR}}$ ratios indicative of euxinia (that is UD-171 16249 and SOL-6 18 051), two other samples with relatively low $\mathrm{Fe}_{\mathrm{Py}} / \mathrm{Fe}_{\mathrm{HR}}$ ratios, from the Lisure Formation (SOL-6 17464 and Z26D-2 11 280), also show a significantly high (aluminum-normalized) Mo enrichment factor (fig. 5C; normalization values from Wedepohl, 1978). Thus, our sample set represents a mixture of anoxic ferruginous and 
euxinic depositional conditions, and syngenetic pyrite oxidation may have altered some of the original $\mathrm{Fe}_{\mathrm{Py}} / \mathrm{Fe}_{\mathrm{HR}}$ ratios.

All samples show $\mathrm{V} /(\mathrm{V}+\mathrm{Ni}$ ) ratio values $\geq 0.55$ (mean: 0.67 , median: 0.69 ; table 2), corresponding to anoxic conditions (Morford and Emerson, 1999). Interestingly, $\mathrm{V} /(\mathrm{V}+\mathrm{Ni})$ correlates with other parameters of our PCA that are interpreted here as soil-derived terrigenous sources, and thus probably delivered to the depositional setting by monsoonal episodes. Such climatic perturbations were seemingly common in mid-Cretaceous tropical zones (Lehmann and others, 1999; Herrle and others, 2003; Browning and Watkins, 2008; Föllmi, 2012; Wagner and others, 2013), and would have delivered soil-sourced vanadium to the shallow anoxic ramp at the time of transgressive black shales alteration to marlstones. Due to the general redox conditions governing early diagenesis of the ramp, vanadium was not largely released from the organic-rich sediments. Yet, some variability observed on the $\mathrm{V} /(\mathrm{V}+\mathrm{Ni})$ proportionality (table 2) may well be linked to variable rates of $\mathrm{Mn}$ - and Fe-cycling in the mixed-sourced sediments (for example Thomazo and others, 2016).

The iron-normalized $\mathrm{Mn}$ concentration $\left(\mathrm{Mn}^{*}\right)$ parameter shows negative correlation $\left(\mathrm{R}_{\mathrm{S}}=-0.88,0.01>P>0.005\right)$ with the terrigenous influx as determined by the proportionality $\mathrm{Al} /(\mathrm{Al}+\mathrm{Fe}+\mathrm{Mn})$, whereas it correlates positively with $\mathrm{Er} / \mathrm{Nd}$ (figs. 8A-8B). The measured intracrystalline Ce anomaly ( $\mathrm{Pr} / \mathrm{Pr}^{*}$, Appendix table A1) has some degree of correlation with the concentration of $\mathrm{Mn}$ in dolomite. This element has concentrations ranging from 34 to $202 \mathrm{ppm}$, but seems homogeneously distributed in the euhedral crystals subjected to $\mu \mathrm{XRF}$ analyses (figs. 8C-8D). The $\mathrm{Pr} / \mathrm{Pr} *$ parameter seems to produce conflicting data when compared with the bulk rock Ce-REE decoupling (fig. 8E), and most of the crystals show depletion in Ce, as measured by their $\mathrm{C}_{\mathrm{anom}}$ values (de Baar and others, 1988; fig. 8F). Such results might as well suggest a diagenetic control exerted by Mn- and Fe-cycling (for example Schijf and Marshall, 2011). In this regard, both the bulk-rock and intracrystalline $\mathrm{Pr} / \mathrm{Pr}$ * ratios (as a measure of the Ce anomaly of the samples), show some degree of negative correlation with the Mn concentrations $\left(\mathrm{R}_{\mathrm{S}}=-0.67, P<0.0001\right)$. However, the detection of the true intracrystalline Ce anomaly, and the actual correlation of such a signal with the intracrystalline $\mathrm{Mn}^{*}$ values, would be affected by the co-occurrence of La anomalies (fig. 8H, Appendix table A1).

To explore if the variability of $\mathrm{Mn} *$ as a function $\mathrm{Al} /(\mathrm{Al}+\mathrm{Fe}+\mathrm{Mn})$ corresponds to an autocorrelation effect, we further evaluated the covariance of bulk rock $\mathrm{Mn} *$, Hf and $\mathrm{Ta}$ (table 2), that is the covariance of $\mathrm{Mn}^{*}$ and elements whose concentrations in these marlstones can be unequivocally associated with detrital aluminosilicates (Bau and Alexander, 2009). There is significant negative correlation between $\mathrm{Mn}^{*}$ and $\mathrm{Hf}$ and Ta $\left(\mathrm{R}_{\mathrm{s}}=0.89\right.$ and 0.87 , respectively, $\left.P>0.001\right)$. This result points to more negative Mn* values at time of increased siliciclastic input. A similar behavior of this parameter was reported by Bellanca and others (1997).

The potential decoupling of $\mathrm{U}$ and Th was also investigated. Uranium can be moderately influenced by redox cycling, and is considered a useful redox proxy when normalized to detrital Th (see Thomazo and others, 2016). Decoupling of $U$ and Th is commonly attributed to variable rates of oxidation of immobile $U$ (IV) to mobile $U$ (VI) during weathering and diagenesis, which results in values that depart from unity (Bau and Alexander, 2009). Therefore, this ratio has been used to quantitatively constrain oxygen levels in sediments potentially affected by mid-Cretaceous anoxic events (for example Sauvage and others, 2013). In the bulk marlstones, the U/Th ranges from 0.22 to 1.09 (mean $=$ median: 0.57 ; table 2 ), while the intracrystalline $\mathrm{U} / \mathrm{Th}$ averaged 0.32 (median: 0.28; Appendix table A1). The non-dolomitic black shale exhibits a higher $\mathrm{U} / \mathrm{Th}$ value than its counterpart with an altered $\mathrm{Fe}_{\mathrm{Py}} / \mathrm{Fe}_{\mathrm{HR}}$ ratio (table 2). However, it should be pointed out that the U/Th of the marlstones are below the 

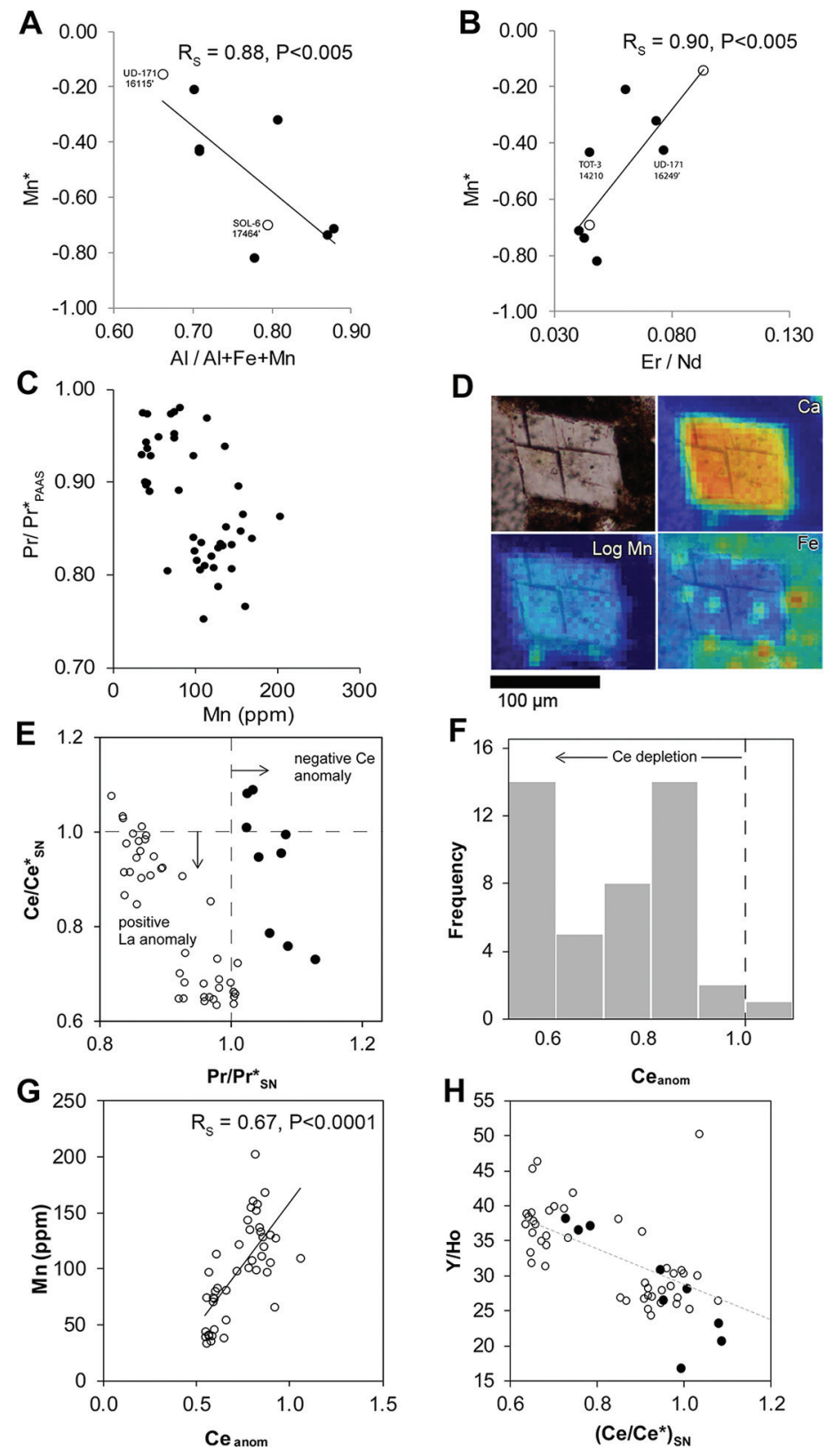

Fig. 8. $\mathrm{Mn}^{*}$ redox parameter and its relation to indicators of terrigenous influx and cerium and lanthanum anomalies in the studied black shales: (A) The samples characterized by a larger terrigenous supply [high $\mathrm{Al} /(\mathrm{Al}+\mathrm{Fe}+\mathrm{Mn})$ ratios], exhibit more negative $\mathrm{Mn} *$ values indicating strongly reducing conditions during deposition. (B) The relation between the $\mathrm{Mn}^{*}$ parameter and the HREE/LREE ratio may be due to the ability of detrital organic material and (oxy)hydroxide mineral phases to concentrate $\mathrm{Nd}$ (LREE) with respect to Er (HREE). As such the longer the sediment-water interface was under geochemical conditions involving utilization of these biologically reactive phases, the higher the proportion of LREE into authigenic dolomite. (C) There is some correlation between the Ce anomaly and the [Mn]. (D)The distribution of $\mathrm{Mn}$ vs. Fe as observed in sample UD-171 16 249'. (E) A variable degree of detrital contamination can be also inferred from the correlated variations between Y/Ho and La anomalies. (F) A binary plot helps discriminate between apparent La and real Ce anomalies. Most of the laser ablated dolomite phases reflect a positive La anomalies. (G) It is possible to normalize the Ce abundances to those of 
range reported by Sauvage and others (2013) for anoxic sediments, which indicates that the sensitivity of this redox proxy is linked to: (1) local environmental conditions (Bau and Alexander, 2009), (2) variable rates of $\mathrm{Fe}-$ and/or Mn-redox cycling (Thomazo and others 2016), and (3) burial diagenetic alteration (Maher and others, 2006; Fantle and others, 2010). Interestingly, U/Th falls within the Category II of our PCA, and is sub-orthogonal to Mn* in the PC1 vs PC2 plot (fig. 4), meaning that variations on this ratio were more likely controlled by the upwelling of reducing basinal waters from the outer ramp, and not by Mn-cycling. Thus, the transport of $\mathrm{U}(\mathrm{VI})$-depleted waters from the Machiques though to the inner ramp setting would had been a more important control over the U/Th values recorded by our samples than the delivery of coupled U(IV) and Th from the catchment area.

PARAGENETIC MODEL

Our integrated analyses point to the lagoonal setting of the Maracaibo ramp as the episodic locus for shallow marine black shale deposition. This occur in association with the development of ferruginous and transient euxinic conditions in the photic zone. These were caused by the expansion of oxygen-depleted nutrient-rich waters from the Machiques trough to the middle to inner ramp settings, and were likely related to minor sea level changes (figs. 9A-9B). In this scenario, relative sea-level lows led to restriction of the differentially subsiding Machiques sub-basin and bottom water anoxia. As sea-level rose, upwelling of anoxic basinal waters to the adjacent shallow ramp caused pervasive reducing conditions and widespread deposition of laminar, organic-rich fine-grained sediments (see Arthur and Sageman, 1994).

The restriction of the ramp allowed for the development of a transiently euxinicferruginous chemocline favorable for framboidal pyrite precipitation. This chemocline was more persistent toward the outer ramp (figs. 9B-9C). However, as the upwelling of oxygen-depleted and nutrient-rich waters from outer to shallow ramp occurred shortly after relative sea level drops (that is the early transgressive stage; see James and others, 2001), the chemocline also develops across the middle to inner ramp lagoonal setting. The shoaling of the oxygen-minimum zone in a general condition of restricted circulation would have been maintained for only short time-scales (for example the time scale represented by our samples), but caused a devastating effect on the carbonate-producing biota and was followed by a complete shutdown of the carbonate factory concomitant with transgressive black shale deposition (figs. 9C-9D).

The Maracaibo ramp had depositional surfaces that remained near sea level during the late Aptian and early Albian (fig. 9), when it shows no evidence of major changes in relative sea level (Renz, 1982; Yurewick and others, 1998; Pöppelreiter and others, 2005; Castillo and Mann, 2006). This allowed repeated replenishment of pore waters by fluids favorable for interstitial dolomite formation in the extended peritidal to shallow subtidal depositional surface. There the organic-rich, fine-grained sediments were deposited only latter to be buried by coastal progradation of cyclic shallow marine carbonates. Our dataset points to interstitial dolomite forming shortly after the onset of pyrite precipitation. The iron speciation data provides good evidence for largely ferruginous, anoxic depositional conditions. The bulk geochemical and bio-

Fig. 8 (continued). its neighboring REE $\left(\mathrm{Ce}\right.$ anomaly $\left.=3 \mathrm{Ce} / \mathrm{Ce} \mathrm{SN} /\left(2 \mathrm{La} / \mathrm{La}_{\mathrm{SN}}+\mathrm{Nd} / \mathrm{Nd}_{\mathrm{SN}}\right)\right)$, yet it is important to point out that these are likely to be biased toward lower values due to the presence of the positive La anomaly. $(\mathrm{H})$ The arrow shows the direction of Ce depletion in seawater (that is complexation to particulate matter. There is some degree of correlation between Ce and Mn contents of dolomite. Note: The open circles represent samples analyzed via LA-ICPQ-MS; the filled circles represent solution-based ICPQ-MS measurements (see online supplementary materials for details; http://earth.geology.yale.edu/ $\%$ 7 eajs/SupplementaryData/2016/Petrash.pdf). 

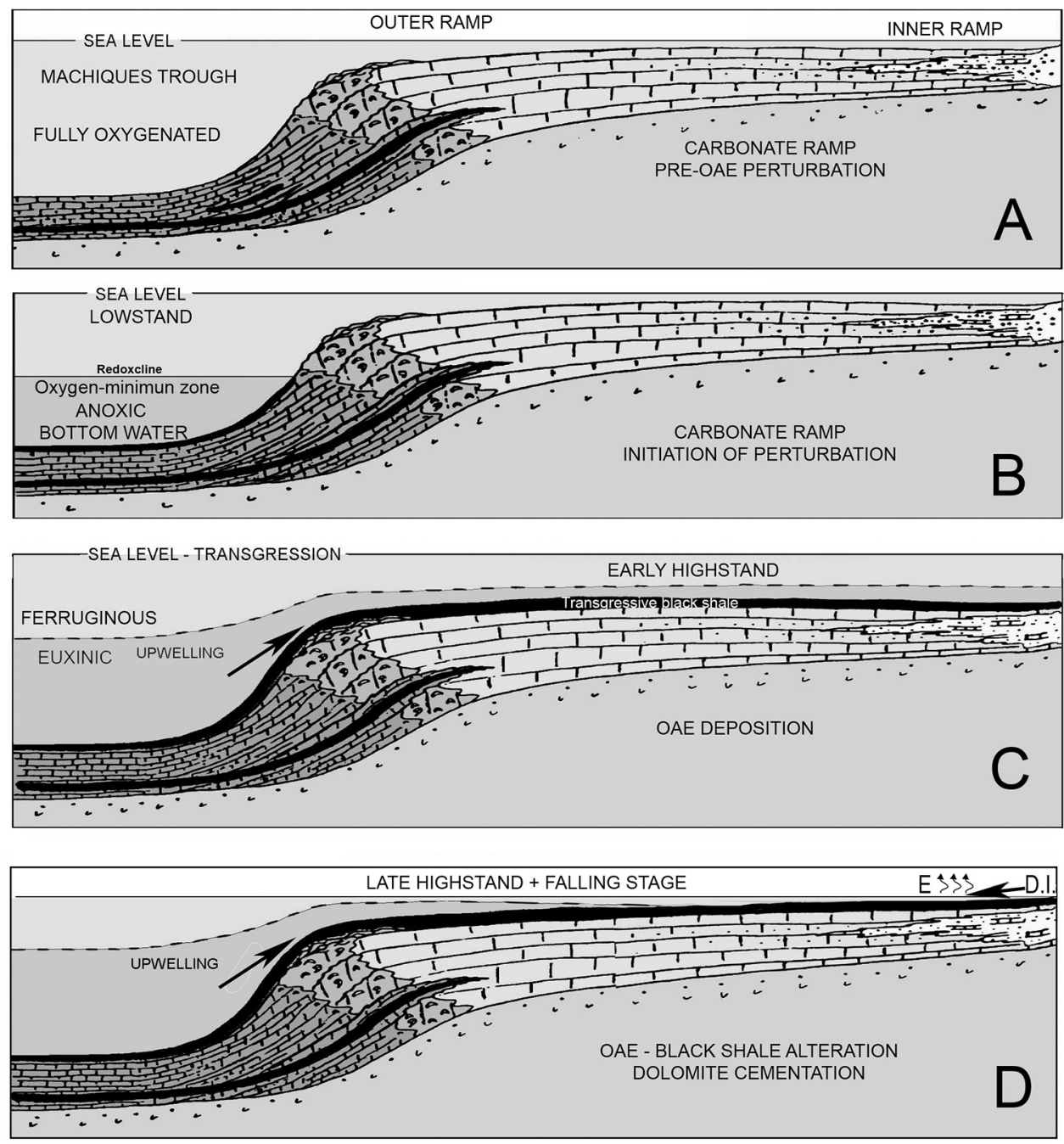

Fig. 9. A model for the depositional environment of black shales in the mid-Cretaceous Maracaibo ramp throughout a single depositional cycle (modified from Mendez-Dot and others, 2015): (A) A pre-anoxic condition and normal oxygenation of the ocean waters in the Machiques sub-basin and Maracaibo ramp allowed for deposition of normal shallow marine carbonates. (B-C) Initiation of anoxia is due to restriction of the basin followed by transgression, with oxygen-exhausted and potentially euxinic waters transported from the sub-basin to the ramp by upwelling currents. This led to transgressive black shale deposition in middle to inner ramp settings. (D) As relative sea level drop during coastal progradation, the organic rich fine-grained sediments were affected by extensive evaporation and transport of terrigenous and continental organic matter during monsoonal events. The development of schizohaline conditions in the lagoonal setting favoured interstitial microbial dolomite formation; D.I.: input of oxidized detrital material from the hinterlands, E: evaporation and subaerial oxidative processes.

marker analyses point to oxidized organics and reactive $\mathrm{Fe}(\mathrm{III})$ - and $\mathrm{Mn}$ (IV)(oxy)hydroxides being transported to the shallow restricted environment by episodic terrigenous fluxes, probably by mid-Cretaceous equatorial monsoon events (see Föllmi, 2012). Then, the rapid reductive dissolution of detrital Fe(III)-(oxy) hydroxides produced ferrous iron, which due to the presence of free biologically produced sulfide was promptly fixed into pyrite framboids, leading to Fe(II)-depleted pore waters (Berner, 
1984; Coleman and others 1993; Raiswell and Canfield, 1998). Sulfide, a limiting reactant under the conditions described above, was made available either by diffusion from adjoining organic-rich levels supporting microbial sulfate reduction, or as supported by the $\mathrm{Fe}_{\mathrm{Py}} / \mathrm{Fe}_{\mathrm{HR}}$ of the samples, by sporadic transport of basinal waters to the shallow ramp.

The rapid abiotic reduction of $\mathrm{Fe}$ (III) favored the biological utilization of $\mathrm{Mn}$, which in the presence of native and evolved forms of intermediate sulfur allowed for enhanced alkalinity and elevated $\mathrm{pH}$ for geologically significant periods of time (for example Petrash and others, 2015). Thus conditions for dolomite stabilization were met (Mazzullo, 2000). This scenario is supported by presence of biomarkers suggestive of an active anoxygenic photosynthetic community at the time of deposition (Appen$\operatorname{dix}$ B). Some of these microorganisms are well-known for their ability to use sulfide as electron donor. During the anoxygenic oxidation process, intermediate forms of sulfur are accumulated (for example Sander and Dahl, 2009). The Mn-(oxy)hydroxides that reacted with elemental sulfur originally scavenged an important fraction of REE. Hence, their reduction is thought responsible for the correlation between bulk $\mathrm{Mn}^{*}$ and $\mathrm{Er} / \mathrm{Nd}$. Manganese would have been recycled a number of times via $\mathrm{Mn}$ (II) reoxidation by the extracellular sulfur stocks and $\mathrm{Mn}(\mathrm{IV})$ reduction with sedimentary organic matter (Petrash and others, 2015). This led to incorporation of Mn into euhedral, chemically homogenous dolomite crystals growing in equilibrium with the iron-depleted pore waters, and produced intracrystalline $\mathrm{Ce}_{\text {anom }}$ and $\mathrm{Pr} / \mathrm{Pr} *$ that exhibit some degree of correlation with the $[\mathrm{Mn}]$ and $\mathrm{Mn}^{*}$ of the dolomite crystals.

As coastal progradation occurred (fig. 9D) some areas of the extended peritidal zone of the ramp would have been subjected to subaerial exposure and localized oxidation of pyrite. This caused a secondary influx of sulfate to the pore water system that prevented the reductive dissolution of barite during shallow burial (for example Von Breymann and others, 1992; Torres and others, 1996). The rocks in which barite was found also show low DBT/Phen ratios $<0.30$ (table 1, see also Appendix table C2), which points to a sulfate-deprived environment of deposition (Hughes and others, 1995). The aluminosilicates comprising up to 56 percent of these rocks are considered major Ba carriers, and barite can be only preserved in sediments deposited under high productivity conditions and with sulfate availability (Dymond and others, 1992; Gingele and Dahmke, 1994; Paytan and others, 1996; Bellanca and others, 1996). Hence, low DBT/Phen ratios and the presence of barite imply that a secondary influx of sulfate occurred in a shallow burial diagenetic realm shortly after the deposition of the mixed-sourced organic-rich fine sediments investigated here. This condition also allowed for the precipitation of equant gypsum in an intimate textural association with early formed dolomite. The precipitation of gypsum inhibited further dolomite growth.

\section{A Competing Dolomite Precipitation Scenario}

Our diagenetic model favors iron and manganese coupled to intermediate sulfur utilization because of the capacity of these mechanisms to serve as effective $\mathrm{pH}$ buffers while simultaneously promoting high alkalinity (see Loyd and others, 2012, their table 4). Nonetheless, an alternative scenario must be also explored, that being the precipitation of dolomite under relatively shallow burial methanogenic conditions (Irwin, 1980; Raiswell, 1988). This mechanism is plausible since all of the marlstones studied here contain $3 \beta$-methylhopanes ( $3 \beta-\mathrm{MHI}$; table 1$)$. Elevated concentrations of these biomarkers, expressed as the methyl hopane index $\left(\mathrm{C}_{31} 3 \beta-\mathrm{MHI}\right)$, are often attributed to the activity of microaerophilic methanotrophs and, by inference, methanogens (Brocks and others, 2003). The biological production of methane in the form of $\mathrm{C}_{\text {org }} \rightarrow \mathrm{CH}_{4}+\mathrm{CO}_{2}$ can drastically lower the $\mathrm{pH}$ of the precipitation environment, and are expected to be corrosive for dolomite previously formed at shallower depth (for 
example Rodriguez and others, 2000). Yet, methanogens employ a number of metabolic pathways, and several of these pathways are capable of promoting carbonate saturation (Roberts and others, 2004; Madigan and Martinko 2005), whereas a pH buffering effect could be exerted by the alteration of silicate, and/or by calcite dissolution and methane oxidative process, which increase alkalinity (Meister and others, 2011).

The ancient presence of methanogens can certainly explain the textural relation of dolomite and pyrite (for example Irwin and others, 1977), and as suggested by Fe and $\mathrm{Mn}$ correlations described in methanogenesis-sourced dolomites, it might also explain some of the inorganic chemical signals observed in our samples (for example Burns and Baker, 1987; Burns and others, 1988; Loyd and others, 2012). In this alternative scenario, exhaustion of sulfate - following microbial sulfate reduction would have favored methanogenesis as the likely fate for most carbon dioxide produced during biodegradation of the sedimentary organic matter (for example Irwin and others, 1977). However, diagenetic dolomite formed in equilibrium with methanogenic waters usually exhibit much heavier $\delta^{13} \mathrm{C}$ values - usually above +8.5 permil (Kelts and McKenzie 1982; Burns and Baker, 1987; Roberts and others 2004), and those observed in our dolomitic marlstones averaged +2.5 permil; median +2.4 permil (table 1).

The characteristic positive signature of methanogenic-sourced dolomites results from the fact that methanogenic archaea discriminate against ${ }^{13} \mathrm{C}$ to generate an isotopically depleted methane, leaving the remaining dissolved inorganic carbon (DIC) enriched in ${ }^{13} \mathrm{C}$ (Claypool and Kaplan, 1974). The isotopically heavy carbonates produced by methanogenesis contrast with the light signatures that should be expected in carbonates formed from either $\mathrm{Mn}(\mathrm{IV}), \mathrm{Fe}(\mathrm{III})$ or sulfate reduction (Coleman and others, 1993), and none of these isotopic carbon signatures are recorded in our samples. In this regard, previous experimental work by Coleman (1985) reported that dilution of the organic isotopic signature with a modern seawater-derived DIC $\left(\delta^{13} \mathrm{C} \approx 0 \%\right.$ ) can shift the ${ }^{13} \mathrm{C}$ content of carbonates formed under $\mathrm{Mn}(\mathrm{IV})$ and $\mathrm{Fe}(\mathrm{III})$ reduction toward heavier values (for example $\delta^{13} \mathrm{C} \approx-10$ and $-5 \%$, respectively), while Irwin (1980) reported that the admixture of methanogenic-and seawaterderived DIC can lead to Fe-dolomite with $\delta^{13} \mathrm{C}$ values ranging from +1.7 to $+8.9 \%$ o (mean: $+6.1 \%$, median: $+7.3 \% \circ ; \mathrm{n}=21$ ).

The $\delta{ }^{13} \mathrm{C}$ carbonate values are relevant for interpretations on dolomite formation mechanisms, yet for determining the involvement of specific metabolism these must be linked to insights offered by the full range of authigenic mineralogies and supported by the geochemistry of the samples. For example, the observation of equant microcrystalline gypsum crystals that are texturally related to dolomite, and the presence of barite in some samples also exhibiting low DBT/Phen ratios (see above), argue against a predominant methanogenic control over interstitial dolomite saturation. This is because in a methanogenic pore water system, the secondary oversaturation of the interstices of the dolomitic marls with sulfate would have led to the anoxygenic oxidation of methane and the precipitation of a distinctively ${ }^{13} \mathrm{C}$ depleted secondary carbonate phase (for example Ritger and others, 1987), but not gypsum and/or barite. Yet, neither methanotrophic nor unambiguous methanogenic carbon isotope signals were recorded by our dolomite crystals, which, except for punctual overgrowths (Appendix A), are generally low in iron as compared with the methanogenic-sourced Jurassic and Neogene dolomites reported by Irwin (1980) and Burns and others (1988), respectively.

Bearing in mind that late Aptian - early Albian seawater was likely enriched in ${ }^{13} \mathrm{C}$ (Menegatti and others, 1998; Naafs and others, 2016), we believe that the $\delta^{13} \mathrm{C}$ of our samples fall within the range that could be expected from dilution of the isotopic 
signature derived from $\mathrm{Mn}(\mathrm{IV})$ and $\mathrm{Fe}(\mathrm{III})$ reduction coupled to the oxidation of sedimentary organic matter by isotopically heavier seawater-derived DIC (for example Coleman, 1985). This interpretation, however, does not exclude some contribution of methanogenically derived ${ }^{13} \mathrm{CO}_{2}$ to the pore-water DIC pool, but points to the problems in using bulk-rock carbon isotope signatures to recognize specific microbial processes (see Raiswell and Fisher, 2000).

The picture that emerges is a mid-Cretaceous Maracaibo ramp being affected, over the time span represented by the dolomitic marlstone intervals targeted here, by the complex interplay between high-frequency sea level changes, climatically driven drying and wetting events, and intrabasinal circulation patterns (fig. 9). These forcing mechanisms induced high rates of subsurface microbial activity, with a substantial environmental control exerted by the episodic expansion of ferruginous/euxinic basinal waters from the adjacent Machiques trough to the restricted lagoonal ramp settings. The evidence points to dolomite forming shortly after the onset of framboidal pyrite precipitation in a shallow burial diagenetic realm affected by episodic monsoonal fluxes of oxidized terrigenous material into an anoxic epicontinental sea, which remained redox stratified. This sequence of events ultimately favored the diagenetic formation of the dolomitic marlstones.

We believe that the complexity of OAE 1-related conditions was recorded by the authigenic mineral assemblage of the marlstones, and particularly by the intricate chemical signals of the dolomite crystals interrogated here. Decoding such signals is not a straight forward process because dolomite is a multigenic mineral sensitive to evolving pore-water chemistries largely driven by the activity of subsurface microbial consortiums. In this regard, our interpretation involving Fe(III) reduction and Mn (IV) recycling represents a modest attempt to decode such signals, but there is mounting evidence for unanticipated symbiotic relations in the dark biosphere that could alter our current views on the mechanism of diagenetic dolomite stabilization (for example Beal and others, 2009; Scheller and others, 2016).

\section{CONCLUSIONS}

In the mid Cretaceous Maracaibo ramp, environmental shifts associated with Milankovitch-scale cyclicity, led to the development of temporarily and spatially restricted microenvironments favorable to early diagenetic dolomite formation. In our paragenetic model, minor modifications in the redox equilibrium conditions caused intense elemental recycling processes that involved microbial $\mathrm{Mn}$ (IV) and $\mathrm{Fe}$ (III) reduction coupled to organic matter remineralization, and resulted in high pore-water alkalinity and interstitial dolomite formation. Orbital perturbations that occurred a few times over periods of $10^{5}$ to $10^{4}$ years, and climatic instability, such as tropical and subtropical mid-Cretaceous monsoons, are believed instrumental for widespread early diagenetic dolomite cementation into the laminar pyritic organic-rich intervals because they allowed the transport of thermodynamically favorable electron acceptors to the organic-rich depositional setting. In this scenario, interstitial dolomite oversaturation resulted from the complex interplay between climatically driven drying and wetting events, high-frequency sea level changes, upwelling, and subsurface microbial activity that produced specific trace metal enrichment trends recorded by our samples and the individual dolomite crystals within them. Finally, similarity in the mineral assemblage, geochemical signatures, and textural features of the microfacies studied here to other OAE-affected successions suggests that the allocyclic controls and general paragenetic mechanism proposed here were important in determining the lateral and vertical distribution of organic-rich dolomitic marlstones in ancient epicontinental basins. 


\title{
ACKNOWLEDGMENTS
}

We are thankful to Robert Gordon (CLS@APS) for technical insights critical for successful analyses at beamline 20ID at the Advanced Photon Source (APS). Use of the APS, an Office of Science User Facility operated for the U.S. Department of Energy (DOE) Office of Science by Argonne National Laboratory, was supported by the U.S. DOE under Contract No. DE-AC02-06CH11357. We thank Karlis Muehlenbachs for supporting our stable isotope analyses, and Leslie J. Robbins for helpful comments to improve an early version of this manuscript. We also thank Jeremy Owens, an anonymous reviewer and the Associate Editor in charge of our submission for their very helpful suggestions that considerably improved the final manuscript. J.J.B. and N.G. thank Janet Hope for technical support, and J.J.B. acknowledges support by the Australian Research Council. S.W.P. acknowledges support by the Natural Environment Research Council Research. K.O.K. acknowledges support by the Natural Sciences and Engineering Council of Canada.

\author{
APPENDices \\ Appendix A \\ AUTHIGENIC MINERALS
}

Standard petrography reveals that the authigenic fraction of the microfacies studied here is dominated by dolomite $(42-48 \%)$, with minor pyrite, and quartz. SEM-EDS show lesser amounts of gypsum, calcite, Ca-fluorapatite, and barite. All of the minerals listed above are within a detrital clayey matrix.

Dolomite

Dolomite occurs as fine- to medium-crystalline $(40-120 \mu \mathrm{m})$ interstitial cement. The mineral is euhedral to subhedral, and the samples contain no mimically replaced allochems. The contacts between fine dolomite and the clayey matrix are typically planar-e, but medium size dolomite crystals, typically exhibiting secondary overgrowths, may also have planar-s crystal boundaries (figs. 3A, C-D). After a mild etching treatment with $10 \% \mathrm{HCl}(10 \mathrm{~s})$, the partial dissolution of these Ca-enriched crystal cores reveal spheroidal features similar to those observed on modern Ca-dolomite formed within mucilage sheaths (fig. A1A). Crystal cortices, on the other hand, are relatively enriched in $\mathrm{Mg}$, and do not exhibit spheroidal features after acid etching. In some samples, the cortices were also found to be chemically zoned, with some degree of Fe-enrichment and near stoichiometric Mg:Ca ratios (fig. A1B). Intracrystalline minor and trace element analysis measured in dolomite from 4 representative samples via LA-ICP-MS are available in Appendix table A1.

\section{Pyrite}

Framboidal pyrite is a common mineral phase in the dolomitic shales from the Apón Formation $(5-8 \%)$. The framboids are often embedded in dolomite cement (figs. A1C-A1D), and sometimes with Ca-F apatite (see below). Most of the individual framboids exhibit sizes averaging 8 to $12 \mu \mathrm{m}$, but small framboids $(<6 \mu \mathrm{m}$ in diameter) were also observed. The crystals comprising the framboids are normally between 0.8 and $2 \mu \mathrm{m}$ in size, but there are also aggregates of equant pyrite nanocrystals that are organized in an irregular non-spheroidal texture (fig. A1E). The crystallites comprising these aggregates and the smaller framboids can be as small as $\sim 300 \mathrm{~nm}$. The small aggregates are more typically observed within the argillaceous matrix (fig. A1E).

\section{Quartz}

Euhedral equant microquartz (15-20 $\mu \mathrm{m}$ in size) is commonly observed within the argillaceous matrix (for example figs. 3E and A1E). Some samples also have chalcedony cement. Chalcedony did not develops as a mineral replacement fabric, but as void filling rims within dolomite and clay (figs. A1F-A1G). Associated with the chalcedonic rims are nanometer-scale features such a globules and fine-scale lamination that suggest that they are silicified endolithic biofilms that grew over dolomite crystal surfaces (see fig. A1G).

Calcite

Partial calcification of dolomite was observed in the sample from borehole Z26D-2. The calcite is low in $\mathrm{Mg}\left(<4\right.$ wt. $\% \mathrm{MgCO}_{3}$ ), and occurs as sub-micrometer scale patches within the core of the crystals. The 

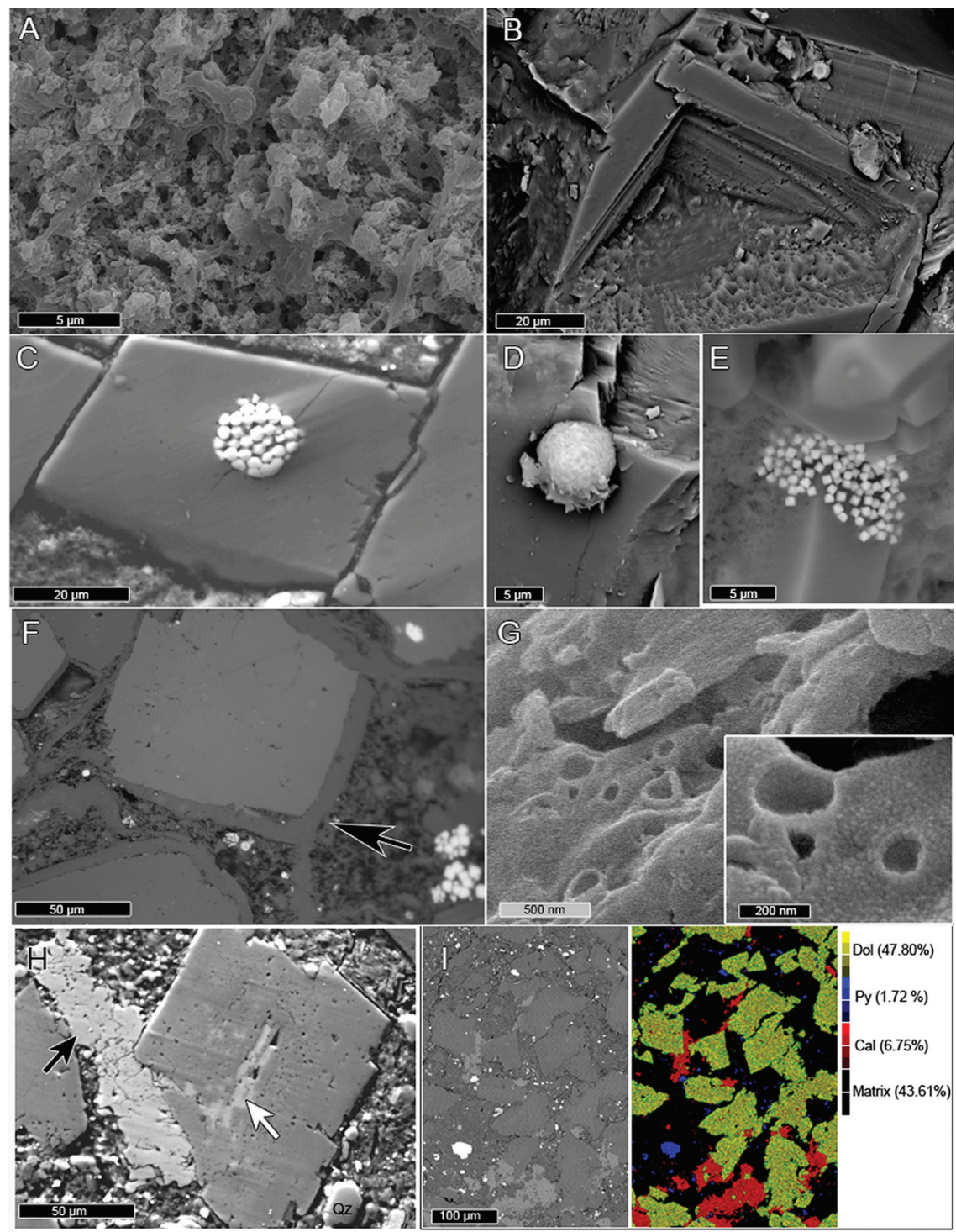

Fig. A1. Additional textural features: (A) After partial leaching with $10 \% \mathrm{HCl}$, the crystals exhibit features that are suggestive of multigenic origin. In the crystal cores it is possible to observe features that look quite similar to modern Ca-dolomite; (B) the crystal cortices, on the other hand, are less soluble $(\mathrm{Mg}$ enriched) and do not exhibit such features. Some cortices are also compositional heterogeneous, and might be Fe enriched. (C-D) Pyrite framboids are often embedded within dolomite. (E) Pyrite is also present in the matrix, where it can also form aggregates of equant pyrite, which are shown here within authigenic quartz (F). Chalcedony can form thin micrometer scale veneers (arrow) around dolomite crystals $(\mathrm{G})$. Within these veneers, there are microtextural features suggestive of an early silicification process of a biofilm. (H-I) Calcite overgrowths might be associated with corroded dolomite crystals.

mineral also occurs as overgrowths adjoining multigenic dolomite that show corroded crystal faces (figs. A1H-A1I); in this sample, gypsum (see below) is notably absent.

Gypsum

In samples from wells TOT-3 (14 210') and SOL-6 (18 008'), as well as in one sample from well UD-171 (16 245.8'), the dolomite crystals are not coated by silica but rather by equant gypsum microcrystals. The 
TABLE Al

In situ elemental concentration data of dolomite

\begin{tabular}{|c|c|c|c|c|}
\hline $\begin{array}{l}\text { Well } \\
\text { Depth (feet) }\end{array}$ & $\begin{array}{l}\text { Z26D-2 } \\
11280^{\dagger}\end{array}$ & $\begin{array}{l}\text { TOT-3 } \\
14210^{\S}\end{array}$ & $\begin{array}{l}\text { UD-171 } \\
16245.8^{\#}\end{array}$ & $\begin{array}{l}\text { UD-171 } \\
16248^{\dagger i}\end{array}$ \\
\hline $\mathbf{N a}(200)^{\S \S}$ & (1819 & 1787 & 2865 & 829 \\
\hline \multirow[t]{2}{*}{ ppm } & 728 & 1139 & 1067 & 657 \\
\hline & 356 & 608 & 650 & 530 \\
\hline $\mathbf{T i}(0.1)$ & 105 & 1787.2 & 91 & 57 \\
\hline \multirow{2}{*}{ ppm } & 52 & 1139 & 46 & 48 \\
\hline & 42 & 608 & 37 & 40 \\
\hline V (4) & 204 & 31 & 29 & 19 \\
\hline \multirow[t]{2}{*}{ ppm } & 108 & 16 & 7 & 11 \\
\hline & 74 & 5 & 3 & 4 \\
\hline $\mathrm{Fe}(0.6)$ & 1.4 & 1.2 & 2.1 & 0.5 \\
\hline \multirow[t]{2}{*}{ wt. $\%$} & 0.4 & 1.1 & 0.7 & 0.3 \\
\hline & 0.1 & 0.5 & 0.1 & 0.1 \\
\hline Mn (14) & 114 & 169 & 203 & 52 \\
\hline \multirow[t]{2}{*}{ ppm } & 79 & 125 & 139 & 41 \\
\hline & 55 & 98 & 98 & 34 \\
\hline $\mathrm{Ni}(5)$ & 143 & 20 & 23 & 11 \\
\hline \multirow[t]{2}{*}{ ppm } & 36 & 12 & 11 & 9 \\
\hline & 15 & 5 & 4 & 4 \\
\hline \multirow{3}{*}{ ppm } & 28 & 0.7 & 3.2 & 0.8 \\
\hline & 9 & 0.4 & 0.7 & 0.4 \\
\hline & 2 & $<$ D.L & $<$ D.L. & 0.2 \\
\hline Y (3) & 49 & 29 & 19 & 36 \\
\hline \multirow[t]{2}{*}{ ppm } & 19 & 20 & 9 & 17 \\
\hline & 12 & 14 & 6 & 11 \\
\hline $\operatorname{Sr}(19)$ & 591 & 744 & 334 & 220 \\
\hline \multirow[t]{2}{*}{ ppm } & 467 & 361 & 212 & 190 \\
\hline & 398 & 256 & 43 & 163 \\
\hline $\mathbf{U}(0.01)$ & 6.9 & 3.3 & 3.3 & 12.9 \\
\hline \multirow[t]{2}{*}{ ppm } & 2.4 & 1.6 & 1.2 & 2.0 \\
\hline & 1.2 & 0.8 & 0.3 & 1.5 \\
\hline Th & 19.7 & 15.9 & 9.3 & 9.9 \\
\hline \multirow{2}{*}{$\mathrm{ppm}$} & 5.6 & 7.5 & 3.7 & 3.8 \\
\hline & 2.0 & 3.6 & 1.7 & 1.6 \\
\hline \multirow[t]{3}{*}{ Y/Ho } & 50.37 & 31.2 & 38.26 & 45.34 \\
\hline & 39.27 & 27.8 & 29.02 & 37.44 \\
\hline & 34.49 & 23.3 & 24.41 & 31.53 \\
\hline \multirow[t]{3}{*}{$\mathbf{P r} / \mathbf{P r} *$} & 0.98 & 0.90 & 0.94 & 0.97 \\
\hline & 0.94 & 0.83 & 0.84 & 0.93 \\
\hline & 0.80 & 0.75 & 0.77 & 0.89 \\
\hline \multirow[t]{3}{*}{$\mathbf{E r} / \mathbf{N d}$} & 0.10 & 0.08 & 0.08 & 0.32 \\
\hline & 0.08 & 0.05 & 0.07 & 0.11 \\
\hline & 0.06 & 0.04 & 0.05 & 0.08 \\
\hline \multirow[t]{3}{*}{$\mathrm{Ce} / \mathrm{Ce}^{*}$} & 1.03 & 1.21 & 0.98 & 0.74 \\
\hline & 0.71 & 0.99 & 0.91 & 0.66 \\
\hline & 0.63 & 0.91 & 0.85 & 0.64 \\
\hline \multirow{3}{*}{$\mathrm{Ce}_{\text {anom }}$} & 0.92 & 1.06 & 0.85 & 0.65 \\
\hline & 0.63 & 0.87 & 0.84 & 0.57 \\
\hline & 34.49 & 0.78 & 0.71 & 0.54 \\
\hline
\end{tabular}

Notes: Values shown are as follow: Maximum, Mean, and Minimum.
${ }^{+} \mathrm{n}=11 ;{ }^{\mathrm{s}} \mathrm{n}=13 ;{ }^{\#} \mathrm{n}=10 ;{ }^{+\dagger} \mathrm{n}=11$ (LA-ICPQ-MS analyses per sample); ${ }^{s_{\text {Averaged }}}$ detection limits. 
mineral was only observed as a cement infilling pre-compaction voids between euhedral dolomite crystals and their argillaceous matrix and is typically associated with fine $(40-50 \mu \mathrm{m})$ dolomite crystals. (figs. 3C-3D). The microcrystals show evidence of compaction (that is planar clay-gypsum interfaces) likely due to the pressure exerted by the crystallization force of gypsum growing against its surrounding. This chemical compaction caused planar intercrystalline boundaries of gypsum and produced local compaction with the clayey matrix forced aside. The textural features of gypsum indicates that this phase can be considered indigenous to these rocks, and not an artifact of pyrite oxidation or from the precipitation of evaporating pore waters after recovery of the cores as interpreted by Patton and others (1984). The microcrystalline gypsum rims do not show textural features that can be interpreted as mineralized biofilms, such as those observed on the chalcedonic rims described above.

\section{Other Accessory Mineral Phases}

Ca-fluorapatite occurs as a pore-lining cryptocrystalline spheroidal phase, typically associated with the organic-rich clayey matrix. It also has a textural association with submicron-scale pyrite (fig. A1E). SEM- EDS analysis also revealed the presence of subhedral micron-sized $(10-30 \mu \mathrm{m})$ barite $\left(\mathrm{BaSO}_{4}\right)$ crystals (fig. $\left.3 \mathrm{G}\right)$.

CLAY MINERALS

Illite was identified by its characteristic $d_{001}$ spacing at circa $10.0 \AA$ A. Kaolinite was identified by its characteristic air-dry basal spacing peaks at 7.1 and $3.6 \AA$, which remains invariant after glycol-solvation (Kirsimäe and others, 1999). When the diffractograms of ethylene glycol-treated and air-dried aliquots of the carbonate-removed samples are compared, the full widths at half-maximum of the 5.0 A peak changed from 0.150 to $0.240 \AA$ (fig. A2A). Such a feature is indicative of the presence of discrete smectite layers (Battaglia and others, 2004). The illite-smectite mixed layers (I/S) gives a 001 peak at a d-value of $\sim 12.9 \AA$, which expands to $16.7 \AA$ after ethylene glycol treatment. The asymmetrical broadening of the air-dried aliquots is significantly diminished after ethylene-glycol treatment (fig. A2A). When considered in terms of a broad peak at ca. $10.0 \AA$ that has a tail toward lower angles, the clay matrix seems dominated by disordered I/S. Semi-quantitative XRD analysis of the $<2 \mu \mathrm{m}$ fraction revealed the following proportions ( $\pm 2 \%$ ): illite $(38 \%)$, kaolinite $(27 \%)$, and disordered I/S clay (35\%); with illite accounting for up to $60 \%$ of that fraction (fig. A2A). Figure A2B shows the morphological features of the fine matrix material as observed in a representative freshly broken sample. A peak at $1,040.98 \mathrm{eV}$, attributed to $\mathrm{Na}$, is frequently observed via EDS within the clay minerals (fig. A2C). The presence of both $\mathrm{Na}$ and $\mathrm{Cl}$ suggests that the sodium peak probably represents halite impurities.

\section{Appendix B}

FURTHER DETAILS ON CAROTENOID DERIVATIVES

The saturated hydrocarbon fraction contains the intact $\mathrm{C}_{40}$ carotenoid derivatives lycopane, $\beta$-carotane and $\gamma$-carotane. The aromatic fractions contain aryl isoprenoids with a 2,3,6-trimethyl substitution pattern in the range $\mathrm{C}_{13}$ to $\mathrm{C}_{31}$, and the $\mathrm{C}_{40}$ parent compound isorenieratane (III), as well as traces of chlorobactane (I) and $\beta$-isorenieratane (II) (fig. B1). Aryl isoprenoids with a 2,3,6-trimethyl substitution pattern may be the cleavage products of aromatic carotenoids with the same substitution pattern, but may also form by aromatization of acyclic carotenoids such as $\beta$-carotane (Koopmans and others, 1997; Brocks and Schaeffer, 2008). The distribution of 2,3,6 breakdown products in the range $C_{30}-C_{31}$ can give clues about the precursor molecules. A linear correlation between $\mathrm{C}_{30}$ and $\mathrm{C}_{31}$ aryl isoprenoid abundances $\left(\mathrm{R}^{2}=0.99\right)$ is evidence for an almost quantitative common biological origin for these two carotenoid breakdown products. The following paragraphs discuss the origins of these compounds and their implications for water column redox conditions.

The biogenic precursor of isorenieratane (III), isorenieratene, has two known biological sources: species of the bacterial phylum Actinobacteria and brown-pigmented strains of Chlorobiaceae (green sulfur bacteria) (Krügel and others, 1999; Ventura and others, 2007; Maresca and others, 2008). Actinobacteria show a wide variety of physiological and metabolic properties and are widely distributed in terrestrial and marine ecosystems (Ventura and others, 2007). Chlorobiaceae are strictly anaerobic, phototrophic bacteria that mainly use sulfide as electron donor, although some species can use ferrous iron (Heising and others, 1999; Frigaard and Bryant, 2006). Populations occur in stratified holomictic and meromictic water bodies, where their density is largest beneath the chemocline, but they also occur in shallow lagoons, stagnant seawater pools, and salt marshes (Overmann and others, 1992; Trüper and Pfennig, 1992 and references within; Manske and others, 2005). Chlorobiaceae also grow in microbial mats (Visscher and Stolz, 2005). In mats as well as in the water column Chlorobiaceae usually thrive below purple sulfur bacteria (Chromatiaceae), which have higher light requirements (Biebl and Pfennig, 1978). 

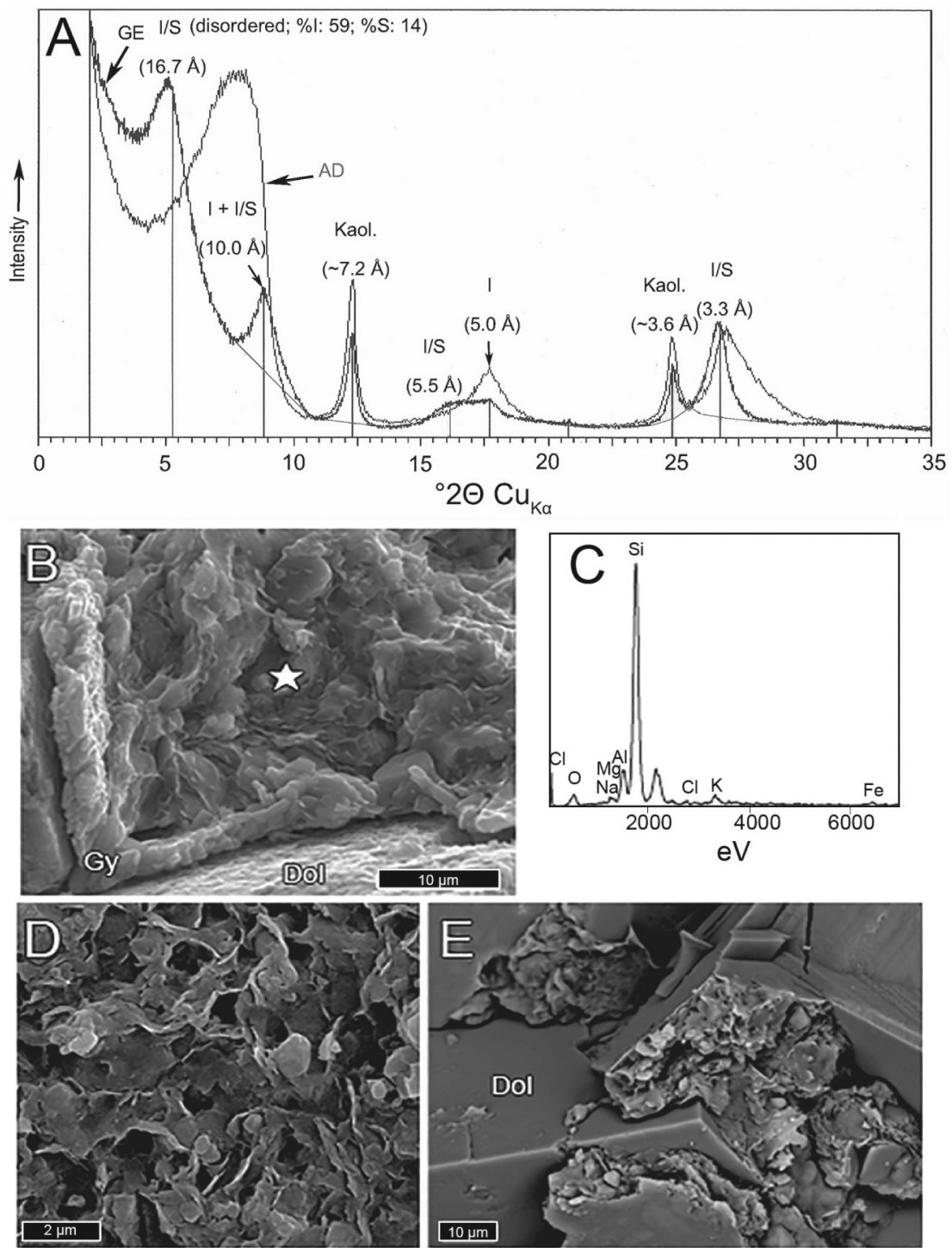

Fig. A2. Clay X-ray powder diffraction analyses: (A) the calculated X-ray powder diffraction profiles illustrate the identification procedures for illite, illite/smectite, and kaolinite; the d-spacing values from $2 \theta$ $\mathrm{Cu} \_\mathrm{K} \alpha$ radiation diffraction angles are labeled. The representative sample (TOT-3 14 210') has 40\% smectite within disordered I/S layers (GE: ethylene glycol spectrum; AD: air dried spectrum). (B-D) Slightly crenulated sodium-bearing clay minerals, as shown via EDS, (D) is a zoom over the area analyzed via EDS (Gy: Gypsum, Dol: dolomite). (E) Pore-filling clays are often packed within dolomite overgrowths.

The cleavage products of isorenieratane (III) are aryl isoprenoids with a 2,3,6 trimethyl substitution pattern. The loss of a terminal phenyl group through $\beta$-cleavage leads to fragments with 10 to 30 carbon atoms. Therefore, a homologue with 31 carbon atoms should not form, as this would require an energetically highly unfavourable cleavage in $\alpha$-position to the aromatic ring. However, in the Maracaibo samples, 2,3,6-aryl isoprenoids include the $\mathrm{C}_{31}$ homologue, which is not produced by isorenieratane cleavage. Moreover, as shown in table $2, \mathrm{C}_{30}$ and $\mathrm{C}_{31}$ homologues are about equally abundant while higher homologues $\left(\geq \mathrm{C}_{32}\right)$ are not detected. The similar abundances indicate that the degradation of isoreni- 


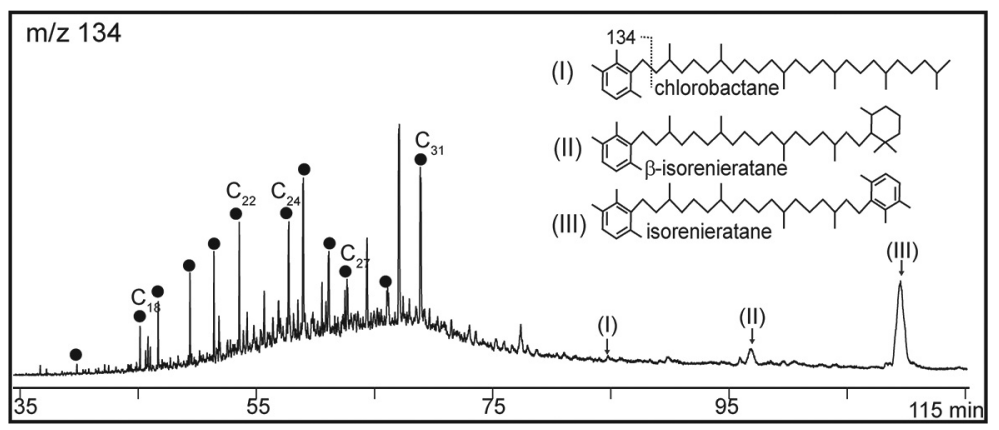

Fig. B1. Aromatic carotenoids derivatives and 2,3,6 aryl isoprenoids (AI) in a representative sample and iron speciation data: (A) In the Maracaibo ramp, the $\mathrm{C}_{31}$ homologue is presumably derived from oxidation and cleavage of a carotenoid with a $\beta$-carotene skeleton. $\mathrm{C}_{\#}$ identifies the carbon number of AIs.

eratene and its derivatives does not account for the bulk of the observed 2,3,6-trimethylated aryl isoprenoids. The pattern can also not be explained by the cleavage of chlorobactane (I), as this would also produce homologues with $>31$ carbon atoms, which are lacking in the samples. Therefore, the source of the bulk of $\leq \mathrm{C}_{31}$ aryl isoprenoids is neither isorenieratene nor chlorobactene but must be a carotenoid that readily loses a $\mathrm{C}_{9}$ unit. One option is $\beta$-isorenieratene. However, its abundance is so low that it can be discounted as a plausible major source.

$\mathrm{C}_{13}$ to $\mathrm{C}_{31}$ 2,3,6-trimethylated aryl isoprenoid may also form by aromatization and cleavage of carotenoids with a $\beta$-carotene skeleton (Koopmans and others, 1996). The aromatization of one ring and cleavage of the second alicyclic ring can account for the observed aryl isoprenoid series, including the presence of abundant $\mathrm{C}_{31}$ and absence of higher pseudohomologues. ${ }^{13} \mathrm{C}$ of values of aryl isoprenoids can, in principle, help differentiating between the two major sources of 2,3,6-aryl isoprenoids: aromatic carotenoids or $\beta$-carotane derivatives (Koopmans and others, 1997). However, aryl isoprenoid concentrations were too low in the shale samples to perform isotopic measurements.

As discussed above, cleavage of isorenieratene did not contribute significantly to the 2,3,6-AI pool, demonstrating that isorenieratene was never significantly exposed to oxygen. Consequently, the bottom waters remained anoxic throughout deposition of the analysed intervals, suggesting permanent and stable stratification with little to no oxygen availability except for perhaps the shallowest waters. This result is consistent with interpretations based on Fe speciation parameters, which suggest a stable anoxic environment with a dominantly ferruginous water column and transitory sulfidic conditions.

ApPendix C

MULTIVARIABLE CORRELATION OF BIOMARKER PARAMETERS

For PCA, the largest point scatter in multidimensional variable space coincides with the direction of the first principal component (PC1). The direction of the second vector (PC2) is second largest point scatter that is at orthogonal to the PC1 direction. Thus, a plot of $\mathrm{PCl}$ versus PC2 represents the best two-dimensional separation of the variables into groups from $n$-dimensional space, and the plane for the first and second principal component vectors has higher information content than any other two-dimensional projection of the data. Further details are available in the online supplementary material (http://earth.geology.yale.edu/ \%7eajs/SupplementaryData/2016/Petrash.pdf). The PC1 clusters the biomarker ratios and some inorganic redox proxies in two distinct categories, Categories I and II. The environmental biomarker parameters comprising both categories are listed in tables C1 and C2, respectively. 


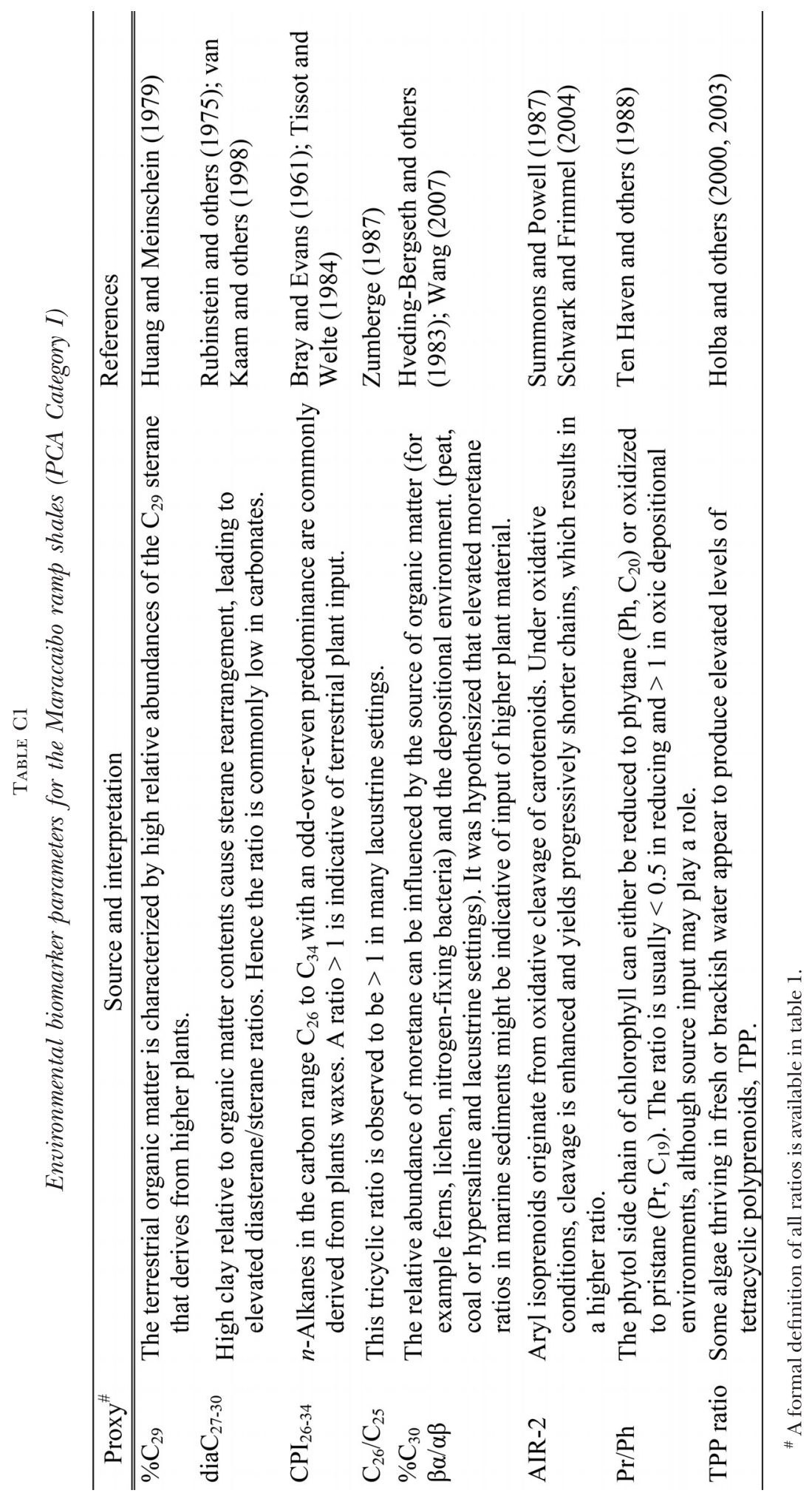


dolomite cementation during Oceanic Anoxic Event 1

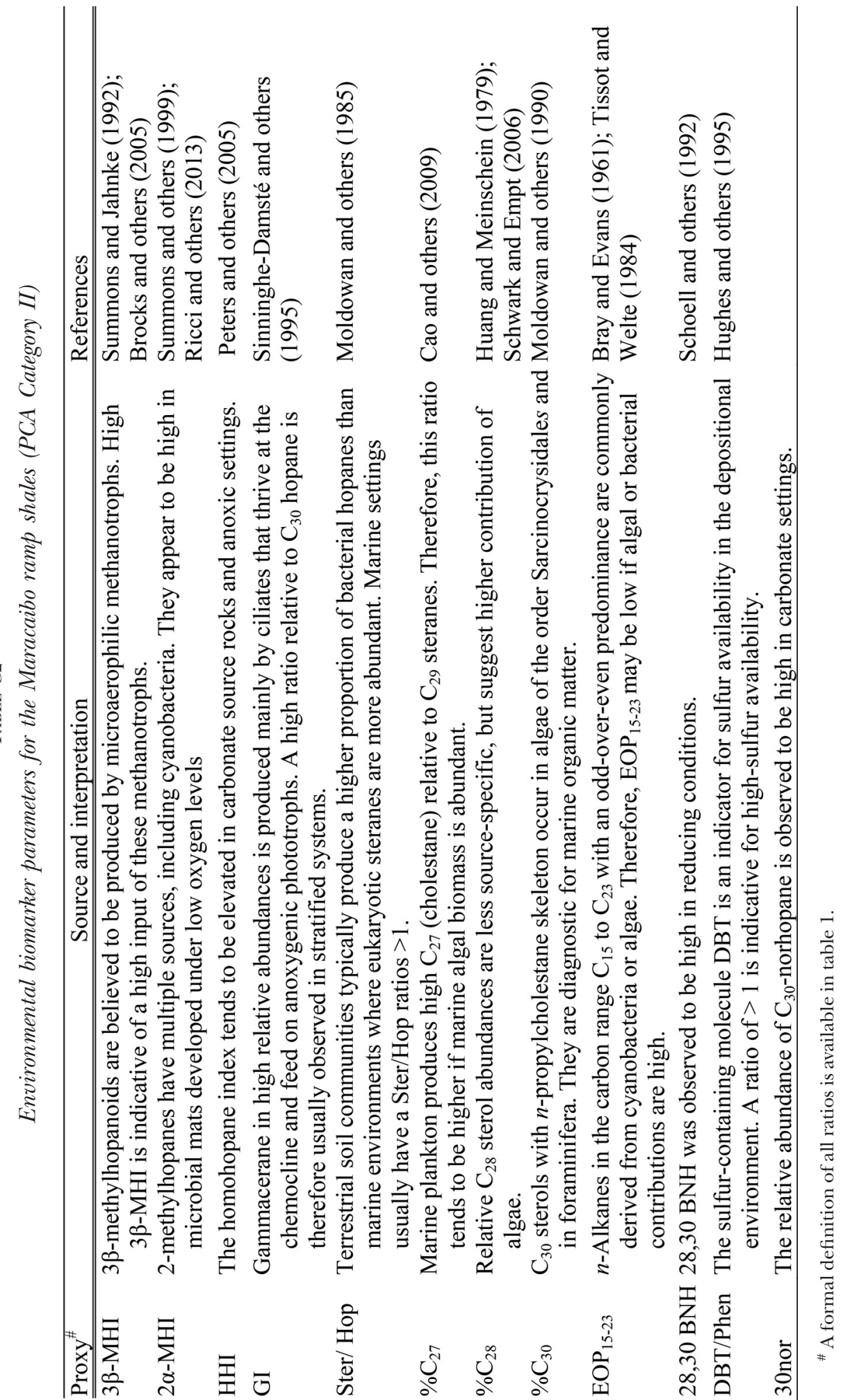




\section{REFERENCES}

Alberdi-Genolet, M., and López, L., 2000, Biomarker 18 alpha (H)-oleanane: A geochemical tool to assess Venezuelan petroleum systems: Journal of South American Earth Sciences, v. 13, n. 8, p. 751-759.

Alberdi-Genolet, M., and Tocco, R., 1999, Trace metals and organic geochemistry of the Machiques Member (Aptian - Albian) and La Luna Formation (Cenomanian - Campanian), Venezuela: Chemical Geology, v. 160, n. 1-2, p. 19-38, http://dx.doi.org/10.1016/S0009-2541(99)00044-3

Arthur, M. A., and Sageman, B. B., 1994, Marine Black Shales: Depositional Mechanisms and Environments of Ancient Deposits: Annual Review of Earth and Planetary Sciences, v. 22, p. 499-551, http:/ /dx.doi.org/ 10.1146/annurev.ea.22.050194.002435

Arthur, M. A., and Schlanger, S. O., 1979, Cretaceous "Oceanic Anoxic Events" as causal factors in development of reef-reservoired giant oil fields: American Association of Petroleum Geologists Bulletin, v. 63 , n. 6 , p. $870-885$.

Arthur, M. A., Dean, W. E., and Stow, D. A. V., 1984, Models for the deposition of Mesozoic-Cenozoic fine-grained organic-carbon-rich sediment in the deep sea, in Stow, D. A. V., and Piper, D. J. W., editors, Fine-grained Sediments: Deep-water Processes and Facies: Geological Society, London, Special Publications, v. 15, p. 527-562, http://dx.doi.org/10.1144/gsl.sp.1984.015.01.34

Arthur, M. A., Dean, W. E., and Schlanger, S. O., 1985, Variations in the global carbon cycle during the Cretaceous related to climate, volcanism, and changes in atmospheric $\mathrm{CO}_{2}$, in Sundquist, E. T., and Broecker, W. S., editor, The Carbon Cycle and Atmospheric CO: Natural Variations Archean to Present: American Geophysical Union, Geophysical Monograph Series, v. 32, p. 504-529, http://dx.doi.org/ $10.1029 / \operatorname{gm} 032 \mathrm{p} 0504$

Arthur, M. A., Jenkyns, H. C., Brumsack, H. J., and Schlanger, S. O., 1990, Stratigraphy, geochemistry, and paleoceanography of organic-carbon rich Cretaceous sequences, in Ginsburg, R. N., and Beaudoin, B., editors, Cretaceous Resources, Events and Rhythms: Dordrecht, Kluwer Academic, NATO AS1 Series, v. 304 p. 75-119, http://dx.doi.org/10.1007/978-94-015-6861-6_6

Bachmann, M., and Hirsch, F., 2006, Lower Cretaceous carbonate platform of the eastern Levant (Galilee and the Golan Heights): Stratigraphy and second-order sea-level change: Cretaceous Research, v. 27, n. 4, p. 487-512, http://dx.doi.org/10.1016/j.cretres.2005.09.003

Barclay, R. S., McElwain, J. C., and Sageman, B. B., 2010, Carbon sequestration activated by a volcanic $\mathrm{CO}_{2}$ pulse during Ocean Anoxic Event 2: Nature Geoscience, v. 3, p. 205-208, http://dx.doi.org/10.1038/ ngeo757

Barling, J., Arnold, G. L., and Anbar, A. D., 2001, Natural mass-dependent variations in the isotopic composition of molybdenum: Earth and Planetary Science Letters, v. 193, n. 3-4, p. 447-457, http://dx.doi.org/10.1016/S0012-821X(01)00514-3

Bartok, P., 1993, Pre-breakup geology of the Gulf of Mexico-Caribbean: Its relation to Triassic and Jurassic rift systems of the region: Tectonics, v. 12, n. 2, p. 441-459, http://dx.doi.org/10.1029/92TC01002

Bartok, P., Reijers, T. J. A., and Juhasz, I., 1981, Lower Cretaceous Cogollo Group, Maracaibo Basin, Venezuela: Sedimentology, diagenesis, and petrophysics: American Association of Petroleum Geologists Bulletin, v. 65, n. 6, p. 1110-1134.

Bathurst, R. G. C., 1987, Diagenetically enhanced bedding in argillaceous platform limestones: Stratified cementation and selective compaction: Sedimentology, v. 34, n. 5, p. 749-778, http://dx.doi.org/ 10.1111/j.1365-3091.1987.tb00801.x

Battaglia, S., Leoni, L., and Sartori, F., 2004, The Kübler index in late diagenetic to low-grade metamorphic pelites: A critical comparison of data from $10 \AA$ and $5 \AA$ peaks: Clays and Clay Minerals, v. 52 , n. 1 , p. 85-105, http://dx.doi.org/10.1346/CCMN.2004.0520109

Bau, M., and Alexander, B. W., 2009, Distribution of high field strength elements (Y, Zr, REE, Hf, Ta, Th, U) in adjacent magnetite and chert bands and in reference standards $\mathrm{FeR}-3$ and $\mathrm{FeR}-4$ from the Temagami iron-formation, Canada, and the redox level of the Neoarchean ocean: Precambrian Research, v. 174, n. 3-4, p. 337-346, http://dx.doi.org/10.1016/j.precamres.2009.08.007

Beal, E. J., House, C. H., and Orphan, V. J., 2009, Manganese- and iron-dependent marine methane oxidation: Science, v. 325, n. 5937, p. 184-187, http://dx.doi.org/10.1126/science.1169984

Bellanca, A., Claps, M., Erba, E., Masetti, D., Neri, R., Premoli Silva, I., and Venezia, F., 1996, Orbitally induced limestone/marlstone rhythms in the Albian - Cenomanian Cismon section (Venetian region, northern Italy): Sedimentology, calcareous and siliceous plankton distribution, elemental and isotope geochemistry: Palaeogeography, Palaeoclimatology, Palaeoecology, v. 126, n. 3-4, p. 227-260, http:// dx.doi.org/10.1016/S0031-0182(96)00041-7

Bellanca, A., Masetti, D., and Neri, R., 1997, Rare earth elements in limestone/marlstone couplets from the Albian-Cenomanian Cismon section (Venetian region, northern Italy): Assessing REE sensitivity to environmental changes: Chemical Geology, v. 2541, p. 141-152, http://dx.doi.org/10.1016/S00092541(97)00058-2

Berner, R. A., 1984, Sedimentary pyrite formation: An update: Geochimica et Cosmochimica Acta, v. 48, n. 4, p. 605-615, http://dx.doi.org/10.1016/0016-7037(84)90089-9

Biebl, H., and Pfennig, N., 1978, Growth yields of green sulfur bacteria in mixed cultures with sulfur and sulfate reducing bacteria: Archives of Microbiology, v. 117, n. 1, p. 9-16, http://dx.doi.org/10.1007/ BF00689344

Bishop, W. F., 1975, Geology of Tunisia and Adjacent Parts of Algeria and Libya: American Association of Petroleum Geologists Bulletin, v. 59, n. 3, p. 413-450.

Bodin, S., Meissner, P., Janssen, N. M. M., Steuber, T., and Mutterlose, J., 2015, Large igneous provinces and organic carbon burial: Controls on global temperature and continental weathering during the Early Cretaceous: Global and Planetary Change, v. 133, p. 238-253, http://dx.doi.org/10.1016/j.gloplacha. 2015.09.001 
Boer, P. L., and Wonders, A. A. H., 1984, Astronomically induced rhythmic bedding in Cretaceous pelagic sediments near Moria (Italy), in Berger, A., Imbrie, J., Hays, J., Kukla, G., and Saltzman, B., editors, Milankovitch and Climate: Massachusetts, Reidel, p. 177-190.

Bolhar, R., and Van Kranendonk, M. J., 2007, A non-marine depositional setting for the northern Fortescue Group, Pilbara Craton, inferred from trace element geochemistry of stromatolitic carbonates: Precambrian Research, v. 155, n. 3-4, p. 229-250, http://dx.doi.org/10.1016/j.precamres.2007.02.002

Bottini, C., Erba, E., Tiraboschi, D., Jenkyns, H. C., Schouten, S., and Sinninghe-Damsté, J. S., 2014, Climate variability and relationship with ocean fertility during the Aptian Stage: Climate of the Past Discussion, v. 10, p. 689-738, http://dx.doi.org/10.5194/cpd-10-689-2014

Bralower, T. J., Arthur, M. A., Leckie, R. M., Sliter, W. V., Allard, D. J., and Schlanger, S. O., 1994, Timing and paleoceanography of oceanic dysoxia/anoxia in the late Barremian to early Aptian (Early Cretaceous): Palaios, v. 9, n. 4, p. 335-369, http://dx.doi.org/10.2307/3515055

Bralower, T. J., Fullagar, P. D., Paull, C. K., Dwyer, G. S., and Leckie, R. M., 1997, Mid-Cretaceous strontium-isotope stratigraphy of deep-sea sections: Geological Society of America Bulletin, v. 109, n. 11, p. 1421-1442, http://dx.doi.org/10.1130/0016-7606(1997) 109<1421:MCSISO > 2.3.CO;2

Bray, E. E., and Evans, E. D., 1961, Distribution of $n$-paraffins as a clue to recognition of source beds: Geochimica et Cosmochimica Acta, v. 22, n. 1, p. 2-15, http://dx.doi.org/10.1016/0016-7037(61)90069-2

Brocks, J. J., and Hope, J. M., 2014, Tailing of chromatographic peaks in GC-MS caused by interaction of halogenated solvents with the ion source: Journal of Chromatographic Science, v. 52, n. 6, p. 471-475, http://dx.doi.org/10.1093/chromsci/bmt068

Brocks, J. J., and Schaeffer, P., 2008, Okenane, a biomarker for purple sulfur bacteria (Chromatiaceae), and other new carotenoid derivatives from the 1640 Ma Barney Creek Formation: Geochimica et Cosmochimica Acta, v. 72, n. 5, p. 1396-1414, http://dx.doi.org/10.1016/j.gca.2007.12.006

Brocks, J. J., and Summons R. E., 2004, Sedimentary hydrocarbons, biomarkers for early life, in Schlesinger, W., editor, Biogeochemistry: Amsterdam, Elsevier, Treatise on Geochemistry, v. 8, p. 63-115, http:// dx.doi.org/10.1016/B0-08-043751-6/08127-5

Brocks, J. J., Buick, R., Logan, G. A., and Summons, R. E, 2003, Composition and syngeneity of molecular fossils from the 2.78-2.45 billion year old Mount Bruce Supergroup, Pilbara Craton, Western Australia: Geochimica et Cosmochimica Acta, v. 67, n. 22, p. 4289-4319, http://dx.doi.org/10.1016/S00167037(03)00208-4

Brocks, J. J., Love, G. D., Summons, R. E., Knoll, A. H., Logan, G. A., and Bowden, S. A., 2005, Biomarker evidence for green and purple sulphur bacteria in a stratified Paleoproterozoic sea: Nature, v. 437, p. 866-870, http://dx.doi.org/10.1038/nature04068

Brooks, J. D., Gould, K., and Smith, J. W., 1969, Isoprenoid hydrocarbons in coal and petroleum: Nature v. 222, p. 257-259, http://dx.doi.org/10.1038/222257a0

Browning, E. L., and Watkins, D. K., 2008, Elevated primary productivity of calcareous nannoplankton associated with ocean anoxic event 1b during the Aptian/Albian transition (Early Cretaceous): Paleoceanography, v. 23, n. 2, p. PA2213, http://dx.doi.org/10.1029/2007PA001413

Burns, S. J., and Baker, P. A., 1987, A geochemical study of dolomites in the Monterey Formation, California: Journal of Sedimentary Petrology, v. 57, n. 1, p. 128-129, http://dx.doi.org/10.1306/212F8AC6-2B2411D7-8648000102C1865D

Burns, S. J., Baker, P. A., and Showers, W. J., 1988, The factors controlling the formation and chemistry of dolomite in organic-rich sediments: Miocene Drakes Bay Formation, California, in Shukla, V., and Baker, P. A., editors, Sedimentology and Geochemistry of Dolostones: SEPM Special Publications, v. 43, p. 41-52, http://dx.doi.org/10.2110/pec.88.43.0041

Butler, I. B., and Rickard, D., 2000, Framboidal pyrite formation via the oxidation of iron (II) monosulfide by hydrogen sulphide: Geochimica et Cosmochimica Acta, v. 64, n. 15, p. 2665-2672, http://dx.doi.org/ 10.1016/S0016-7037(00)00387-2

Canfield, D. E., Raiswell, R. J., Westrich, J. T., Reaves, C. M., and Berner, R. A., 1986, The use of chromium reduction in the analysis of reduced inorganic sulfur in sediments and shales: Chemical Geology, v. 54, n. 1-2, p. 149-155, http://dx.doi.org/10.1016/0009-2541(86)90078-1

Canfield, D. E., Raiswell, R., and Bottrell, S., 1992, The reactivity of sedimentary iron minerals toward sulfide: American Journal of Science, v. 292, n. 9, p. 659-683, http://dx.doi.org/10.2475/ajs.292.9.659

Cao, C., Love, G. D., Hays, L. E., Wang, W., Shen, S., and Summons, R. E., 2009, Biogeochemical evidence for euxinic oceans and ecological disturbance presaging the end-Permian mass extinction event: Earth and Planetary Science Letters, v. 281, n. 3-4, p. 188-201, http://dx.doi.org/10.1016/j.epsl.2009.02.012

Castillo, M. V., and Mann, P., 2006, Cretaceous to Holocene structural and stratigraphic development in south Lake Maracaibo, Venezuela, inferred from well and three-dimensional seismic data: American Association of Petroleum Geologists Bulletin, v. 90, n. 4, p. 529-565, http://dx.doi.org/10.1306/ 10130505036

Claps, M., Masetti, D., Pedrielli, E., and Garavello, A. L., 1991, Analisi spettrale e cicli di Milankovitch in successione cretaciche del Sudalpino orientale (Spectral analysis of Milankovitch cycles in the Cretaceous succession of the southeastern Alps): Rivista Italiana di Paleontologia e Stratigrafia, v. 97, n. 2, p. 153-174.

Claypool, G. E. and Kaplan, I. R., 1974, The origin and distribution of methane in marine sediments, in Kaplan, I. R., editor, Natural Gases in Marine Sediments: New York, Plenum Publishing Corporation, Marine Sciences, v. 3, p. 99-139, http://dx.doi.org/10.1007/978-1-4684-2757-8_8

Coleman, M. L., 1985, Geochemistry of diagenetic non-silicate minerals: Kinetic considerations: Philosophical Transactions of the Royal Society A: Mathematical, Physical and Engineering Science A, v. 315, n. 1531, p. 39-56, http://dx.doi.org/10.1098/rsta.1985.0028

Coleman, M., Raiswell, R., Brown, A., Curtis, C., Aplin, A. C., Ortoleva, P. J., Gruszczynski, M., Lyons, T., Lovley, D. R., and Eglinton, G., 1993, Microbial mineralization of organic matter: Mechanisms of 
self-organization and inferred rates of precipitation of diagenetic minerals [and Discussion]: Philosophical Transactions of the Royal Society of London A: Mathematical, Physical and Engineering Sciences, 344, n. 1670, p. 69-87, http://dx.doi.org/10.1098/rsta.1993.0076

Craig, H., 1957, Isotopic standards for carbon and oxygen and correction factors for mass-spectrometric analysis of carbon dioxide: Geochimica et Cosmochimica Acta, v. 12, n. 1-2, p. 133-149, http:// dx.doi.org/10.1016/0016-7037(57)90024-8

_ 1961, Standards for reporting concentrations of deuterium and oxygen-18 in natural waters: Science, v. 133, n. 3467, p. 1833-1834, http://dx.doi.org/10.1126/science.133.3467.1833

Craig, H., Gordon, L. I., and Horibe, Y., 1963, Isotopic exchange effects in the evaporation of water: 1. Low-temperature experimental results: Journal of Geophysical Research, v. 68, n. 17, p. 5079-5087, http://dx.doi.org/10.1029/JZ068i017p05079

Davranche, M., Pourret, O., Gruau, G., Dia, A., Jin, D., and Gaertner, D., 2008, Competitive binding of REE to humic acid and manganese oxide: Impact of reaction kinetics on development of cerium anomaly and REE adsorption: Chemical Geology, v. 247, n. 1-2, p. 154-170, http://dx.doi.org/10.1016/ j.chemgeo.2007.10.010

de Baar, H.J. W., German, C. R., Elderfield, H., and van Gaans, P., 1988, Rare earth element distributions in anoxic waters of the Cariaco Trench: Geochimica et Cosmochimica Acta, v. 52, n. 5, p. 1203-1219, http://dx.doi.org/10.1016/0016-7037(88)90275-X

de Baar, H. J. W., Schijf, J., and Byrne, R. H., 1991, Solution chemistry of the rare earth elements in seawater: Solid State Inorganic Chemistry, v. 28, p. 357-373.

Dembicki, H., Jr., Meinschein, W. G., and Hattin, D. E., 1976, Possible ecological and environmental significance of the predominance of even-carbon number $\mathrm{C}_{20}-\mathrm{C}_{30} n$-alkanes: Geochimica et Cosmochimica Acta, v. 40, n. 2, p. 203-208, http://dx.doi.org/10.1016/0016-7037(76)90177-0

Dewers, T., and Ortoleva, P., 1994, Formation of stylolites, marl/limestone alternations, and dissolution (clay) seams by unstable chemical compaction of argillaceous carbonates: Developments in Sedimentology, v. 51, p. 155-216, http://dx.doi.org/10.1016/S0070-4571(08)70440-0

Didky, B. M., Simoneit, B. R. T., Brassel, S. C., and Eglinton, G., 1978, Organic geochemical indicators of palaeoenvironmental conditions of sedimentation: Nature, v. 272, p. 216-222, http://dx.doi.org/ $10.1038 / 272216 \mathrm{a} 0$

Dumitrescu, M., and Brassell, S. C., 2005, Biogeochemical assessment of sources of organic matter and paleoproductivity during the early Aptian Oceanic Anoxic Event at Shatsky Rise, ODP Leg 198: Organic Geochemistry, v. 36, n. 7, p. 1002-1022, http://dx.doi.org/10.1016/j.orggeochem.2005.03.001

Dymond, J., Suess, E., and Lyle, M., 1992, Barium in deep-sea sediment: A proxy for paleoproductivity: Paleoceanography, v. 7, n. 2, p. 163-181, http://dx.doi.org/10.1029/92PA00181

Edwards, W., 1933, On the Cretaceous fern Paradoxopteris and its connexion with Weichselia: Annals of Botany, v. 47 , p. $317-341$.

Eglinton, G., Gonzalez, A. G., Hamilton, R. J., and Raphael, R. A., 1962, Hydrocarbon constituents of the wax coatings of plant leaves: A taxonomic survey: Phytochemistry, v. 1, n. 2, p. 89-102, http://dx.doi.org/ 10.1016/S0031-9422(00)88006-1

Erba, E., 2004, Calcareous nannofossils and Mesozoic oceanic anoxic events: Marine Micropaleontology, v. 52, n. 1-4, p. 85-106, http://dx.doi.org/10.1016/j.marmicro.2004.04.007

Erbacher, J., Thurow, J., and Littke, R., 1996, Evolution patterns of radiolaria and organic matter variations: A new approach to identify sea-level changes in mid-Cretaceous pelagic environments: Geology, v. 24, n. 6, p. 499-502, http:/ / dx.doi.org/10.1130/0091-7613(1996) 024<0499:EPORAO > 2.3.CO;2

Erbacher, J., Huber, B. T., Norris, R. D., and Markey, M., 2001, Increased thermohaline stratification as a possible cause for an ocean anoxic event in the Cretaceous period: Nature, v. 409, p. 325-327, http://dx.doi.org/10.1038/35053041

Fantle, M. S., Maher, K. M., and DePaolo, D. J., 2010, Isotopic approaches for quantifying the rates of marine burial diagenesis: Reviews of Geophysics, v. 48, n. 3, p. 1-38, http://dx.doi.org/10.1029/2009rg000306

Fisher, W. L., and Rodda, P. U., 1969, Edwards Formation (Lower Cretaceous), Texas: Dolomitization in a carbonate platform system: American Association of Petroleum Geologists Bulletin, v. 53, n. 1, p. 55-72.

Folk, R. L., and Siedlecka, A., 1974, The "schizohaline" environment: Its sedimentary and diagenetic fabrics as exemplified by Late Paleozoic rocks of Bear Island, Svalbard: Sedimentary Geology, v. 11, n. 1, p. 1-15, http:/ /dx.doi.org/10.1016/0037-0738(74)90002-5

Föllmi, K. B., 2012, Early Cretaceous life, climate and anoxia: Cretaceous Research, v. 35, p. 230-257, http://dx.doi.org/10.1016/j.cretres.2011.12.005

Ford, A. B., and Houbolt, J. J. H. C., 1963, The microfacies of the Cretaceous of western Venezuela: Leiden, The Netherlands, E. J. Brill, 55 p.

Frigaard, N.-U., and Bryant, D. A., 2006, Chlorosomes: antenna organelles in photosynthetic green bacteria, in Shively, J. M. editor, Complex intracellular structures in prokaryotes: Berlin, Springer Science \& Business Media, Microbiology Monographs, v. 2, p. 79-114.

Furnes, H., McLoughlin, N., Muehlenbachs, K., Banerjee, N. R., Staudigel, H., Dilek, Y., de Wit, M., Van Kranendonk, M., and Schiffmann, P., 2008, Oceanic pillow lavas and hyaloclastites as habitats for microbial life through time: A review, in Dilek, Y., Furnes, H., and Muehlenbachs, K., editors, Links between geological processes, microbial activities, and evolution of life: Berlin, Springer Book Series, p. $1-68$.

Gaona-Narvaez, T., Maurrasse, F. J. M. R., and Etayo-Serna, F., 2013, Geochemistry, palaeoenvironments and timing of Aptian organic-rich beds of the Paja Formation (Curití, Eastern Cordillera, Colombia): Geological Society, London, Special Publications, v. 382, p. 31-48, http://dx.doi.org/10.1144/SP382.6

Gelpi, E., Schneider, H., Mann, J., and Oro, J., 1970, Hydrocarbons of geochemical significance in microscopic algae: Phytochemistry, v. 9, n. 3, p. 603-612, http://dx.doi.org/10.1016/S00319422(00) 85700-3 
Gingele, F. X., and Dahmke, A., 1994, Discrete barite particles and barite as tracers of paleoproductivity in South Atlantic sediments: Paleoceanography, v. 9, n. 1, p. 151-168, http://dx.doi.org/10.1029/ 93PA02559

Given, R. K., and Wilkinson, B. H., 1987, Dolomite Abundance and Stratigraphic Age: Constraints on Rates and Mechanisms of Phanerozoic Dolostone Formation: Journal of Sedimentary Petrology, v. 57, n. 6, p. 1068-1078, http://dx.doi.org/10.1306/212F8CF1-2B24-11D7-8648000102C1865D

González de Juana, C., Arozena, J., and Picard, X. C., 1980, Geología de Venezuela y de sus Cuencas Petrolíferas: Caracas, Venezuela, Ediciones Foninves, 1031 p.

Grabenstatter, J., Méhay, S., McIntyre-Wressnig, A., Giner, J. L., Edgcomb, V. P., Beaudoin, D. J., Bernhard, J. M., and Summons, R. E., 2013, Identification of 24- $n$-propylidenecholesterol in a member of the Foraminifera: Organic Geochemistry, v. 63, p. 145-151, http://dx.doi.org/10.1016/j.orggeochem. 2013.08.010

Grantham, P. J., and Wakefield, L. L., 1988, Variations in the sterane carbon number distributions of marine source rock derived crude oils through geological time: Organic Geochemistry, v. 12, n. 1, p. 61-73, http://dx.doi.org/10.1016/0146-6380(88)90115-5

Grimalt, J., and Albaigés, J., 1987, Sources and occurrence of $\mathrm{C}_{12}-\mathrm{C}_{22} n$-alkane distributions with even carbon-number preference in sedimentary environments: Geochimica et Cosmochimica Acta, v. 51, n. 6, p. 1379-1384, http://dx.doi.org/10.1016/0016-7037(87)90322-X

Hallam, A., 1986, Origin of minor limestone-shale cycles: Climatically induced or diagenetic?: Geology v. 14, n. 7, p. 609-612, http://dx.doi.org/10.1130/0091-7613(1986) $14<609$ :OOMLCC $>2.0 . C O ; 2$

Halley, R. B., 1985, Setting and geological summary of the Lower Cretaceous, Sunniland Field, southern Florida, in Roehl, P. O., and Choquette, P. W., editors, Carbonate Petroleum Reservoirs: New York, Springer, p. 443-454, http://dx.doi.org/10.1007/978-1-4612-5040-1_28

Haq, B. U., Hardenbol, J., and Vail, P. R., 1987, Chronology of fluctuating sea levels since the Triassic: Science, v. 235, n. 4793, p. 1156-1167, http://dx.doi.org/10.1126/science.235.4793.1156

Harvey, H. R., and Mcmanus, G. B., 1991, Marine ciliates as a widespread source of tetrahymanol and hopan-3ß-ol in sediments: Geochimica et Cosmochimica Acta, v. 55, n. 11, p. 3387-3390, http:// dx.doi.org/10.1016/0016-7037(91)90496-R

Hay, W. W., Migdisov, A., Balukhovsky, A. N., Wold, C. N., Flögel, S., and Söding, E., 2006, Evaporites and the salinity of the ocean during the Phanerozoic: Implications for climate, ocean circulation and life, in Buggisch, W., editor, Evolution of the System Earth in the Late Palaeozoic: Clues from Sedimentary Geochemistry: Palaeogeography, Palaeoclimatology, Palaeoecology, v. 240, n. 1-2, p. 3-46, http:/) dx.doi.org/10.1016/j.palaeo.2006.03.044

Heising, S., Richter, L., Ludwig, W., and Schink, L. B., 1999, Chlorobium ferrooxidans sp. nov., a phototrophic green sulfur bacterium that oxidizes ferrous iron in coculture with a Geospirillum sp. Strain: Archives of Microbiology, v. 172, n. 2, p. 116-124, http://dx.doi.org/10.1007/s002030050748

Helz, G. R., Miller, C. V., Charnock, J. M., Mosselmans, J. F. W., Pattrick, R. A. D., Garner, C. D., and Vaughan, D. J., 1996, Mechanism of molybdenum removal from the sea and its concentration in black shales: EXAFS evidence: Geochimica et Cosmochimica Acta, v. 60, n. 19, p. 3631-3642, http://dx.doi.org/ 10.1016/0016-7037(96)00195-0

Herrle, J., Pross, J., and Friedrich, O., 2003, Forcing mechanisms for mid-Cretaceous black shale formation: Evidence from the Upper Aptian and Lower Albian of the Vocontian Basin (SE France): Palaeogeography, Palaeoclimatology, Palaeoecology, v. 190, 399-426, http://dx.doi.org/10.1016/S0031-0182 (02) 00616-8

Herrle, J. O., Kößler, P., Friedrich, O., Erlenkeuser, H., and Hemleben, C., 2004, High-resolution carbon isotope records of the Aptian to Lower Albian from SE France and the Mazagan Plateau (DSDP Site 545): A stratigraphic tool for paleoceanographic and paleobiologic reconstruction: Earth and Planetary Science Letters, v. 218, n. 1-2, p. 149-161, http://dx.doi.org/10.1016/S0012-821X(03)00646-0

Holba, A. G., Tegelaar, E., Ellis, L., Singletary, M. S., and Albrecht, P., 2000, Tetracyclic polyprenoids: Indicators of freshwater (lacustrine) algal input: Geology, v. 28, n. 3, p. 251-254, http://dx.doi.org/ 10.1130/0091-7613(2000) 28<251:TPIOFL>2.0.CO;2

Holba, A. G., Dzou, L. I., Wood, G. D., Ellis, L., Adam, P., Schaeffer, P., Albrecht, P., Greene, T., and Hughes, W. B., 2003, Application of tetracyclic polyprenoids as indicators of input from fresh-brackish water environments: Organic Geochemistry v. 34, n. 3, p. 441-469, http://dx.doi.org/10.1016/S0146$6380(02) 00193-6$

Huang, W. -Y., and Meinschein, W. G., 1979, Sterols as ecological indicators: Geochimica et Cosmochimica Acta, v. 43, n. 5, p. 739-745, http://dx.doi.org/10.1016/0016-7037(79)90257-6

Hughes, W. B., Holba, A. G., and Dzou, L. I. P., 1995, The ratios of dibenzothiophene to phenanthrene and pristane to phytane as indicators of depositional environment and lithology of petroleum source rocks: Geochimica et Cosmochimica Acta v. 59, n. 17, p. 3581-98, http://dx.doi.org/10.1016/00167037(95) 00225-O

Hveding-Bergseth, N., Bruun, T., and Kjøsen, H., 1983, Isolation of 30-nor-21 $\alpha$-hopan-22-one (isoadiantone) from the lichen Platismatia glauca: Phytochemistry, v. 22, n. 8, p. 1826-1827, http://dx.doi.org/ 10.1016/S0031-9422(00)80283-6

Illich, H. A., 1983, Pristane, phytane, and lower molecular weight isoprenoid distributions in oils: American Association of Petroleum Geologists Bulletin, v. 67, n. 3, p. 385-393.

Irwin, H., 1980, Early diagenetic carbonate precipitation and pore fluid migration in the Kimmeridge Clay of Dorset, England: Sedimentology, v. 27, n. 5, p. 577-591, http://dx.doi.org/10.1111/j.13653091.1980.tb01648.x

Irwin, H., Curtis, C., and Coleman, M., 1977, Isotopic evidence for source of diagenetic carbonates formed during burial of organic-rich sediments: Nature, v. 269, p. 209-213, http://dx.doi.org/10.1038/ $269209 \mathrm{a} 0$ 
James, N. P., Bone, Y., Collins, L. B., and Kyser, T. K., 2001, Surficial Sediments of the Great Australian Bight: Facies Dynamics and Oceanography on a Vast Cool-Water Carbonate Shelf: Journal of Sedimentary Research, v. 71, n. 4, p. 549-567, http://dx.doi.org/10.1306/102000710549

Jarrett, A. J. M., Schinteie, R., Hope, J. M., and Brocks, J. J., 2013, Micro-ablation, a new technique to remove drilling fluids and other contaminants from fragmented and fissile rock material: Organic Geochemistry, v. 61, p. 57-65, http://dx.doi.org/10.1016/j.orggeochem.2013.06.005

Jenkyns, H. C., 2010, Geochemistry of oceanic anoxic events: Geochemistry, Geophysical, Geosystems, v. 11, n. 3, http://dx.doi.org/10.1029/2009GC002788

Jones, B., Luth, R. W., and MacNeil, A. J., 2001, Powder X-ray diffraction analysis of homogeneous and heterogeneous sedimentary dolostones: Journal of Sedimentary Research, v. 71, n. 5, p. 790-799, http:/ /dx.doi.org/10.1306/2DC40968-0E47-11D7-8643000102C1865D

Kamber, B. S., Bolhar, R., and Webb, G. E., 2004, Geochemistry of late Archaean stromatolites from Zimbabwe: Evidence for microbial life in restricted epicontinental seas: Precambrian Research, v. 132, n. 4, p. 379-399, http://dx.doi.org/10.1016/j.precamres.2004.03.006

Kelts, K., and McKenzie, J. A., 1982, Diagenetic dolomite formation in Quaternary anoxic diatomaceous muds of Deep Sea Drilling Project Leg 64, Gulf of California: Initial Reports of the Deep Sea Drilling Project, v. 64, p. 553-569, http://dx.doi.org/10.2973/dsdp.proc.64.110.1982

Kirsimäe, K., Jørgensen, P., and Kalm, V., 1999, Low-temperature diagenetic illite-smectite in Lower Cambrian clays in North Estonia: Clay Minerals, v. 34, n. 1, p. 151-163, http://dx.doi.org/10.1180/ 000985599546000

Knauth, L. P., and Kennedy, M. J., 2009, The late Precambrian greening of the Earth: Nature, v. 460, p. 728-732, http://dx.doi.org/10.1038/nature08213

Koopmans, M. P., Schouten, S., Kohnen, M. E. L., and Sinninghe-Damsté, J. S., 1996, Restricted utility of aryl isoprenoids as indicators for photic zone anoxia: Geochimica et Cosmochimica Acta, v. 60, n. 23, p. 4873-4876, http://dx.doi.org/10.1016/S0016-7037(96)00303-1

Koopmans, M. P., De Leeuw, J. W., and Sinninghe-Damsté, J. S. S., 1997, Novel cyclised and aromatised diagenetic products of $\beta$-carotene in the Green River Shale: Organic Geochemistry, v. 26, n. 7-8, p. 51-466, http://dx.doi.org/10.1016/S0146-6380(97)00025-9

Krügel, H., Krubasik, P., Weber, K., Saluz, H. P., and Sandmann, G., 1999, Functional analysis of genes from Streptomyces griseus involved in the synthesis of isorenieratene, a carotenoid with aromatic end groups, revealed a novel type of carotenoid desaturase: Biochimica et Biophysica Acta (BBA) -Molecular and Cell Biology of Lipids, v. 1439, n. 1, p. 57-64, http://dx.doi.org/10.1016/S1388-1981(99)00075-X

Kump, L. R., and Arthur, M. A., 1999, Interpreting carbon-isotope excursions: Carbonates and organic matter: Chemical Geology, v. 161, n. 1-3, p. 181-198, http://dx.doi.org/10.1016/S0009-2541(99)00086-8

Kuypers, M. M. M., Blokker, P., Erbacher, J., Kinkel, H., Pancost, R. D., Schouten, S., and Sinninghe-Damsté, J. S., 2001, Massive expansion of marine archaea during a mid-Cretaceous oceanic anoxic event: Science, v. 293, n. 5527, p. 92-95, http://dx.doi.org/10.1126/science.1058424

Kuypers, M. M. M., Blokker, P., Hopmans, E. C., Kinkel, H., Pancost, R. D., Schouten, S., and SinningheDamsté, J. S., 2002, Archaeal remains dominate marine organic matter from the early Albian oceanic anoxic event 1b: Palaeogeography, Palaeoclimatology, Palaeoecology, v. 185, n. 1-2, p. 211-234, http://dx.doi.org/10.1016/S0031-0182(02)00301-2

Lacovara, K. J., Smith, J. R., Smith, J. B, Lamanna, M. C., and Dodson. P., 2000, Paralic environments of the Cretaceous dinosaurs of Egypt: a discussion of uniformitarian analogs: Journal of Vertebrate Paleontology, v. 20. p. 53.

Lacovara, K. J., Smith, J. R., Smith, J. B., and Lamanna, M. C., 2003, The Ten Thousand Islands Coast of Florida: A modern analog to low-energy mangrove coasts of Cretaceous epeiric seas, in Davies, R. A. J., editor, Proceedings of the 5th International Conference on Coastal Sediments, Clearwater Beach, Florida: Corpus Christi, Texas, CD-ROM Published by World Scientific Publishing Corporation and East Meets West Productions, p. 1773-1784.

Larson, R. L., an Erba, E., 1999, Onset of the Mid-Cretaceous greenhouse in the Barremian-Aptian: Igneous events and the biological, sedimentary, and geochemical responses: Paleoceanography, v. 14, n. 6 , p. 663-678, http://dx.doi.org/10.1029/1999PA900040

Leckie, R. M., Bralower, T. J., and Cashman, R., 2002, Oceanic anoxic events and plankton evolution: Biotic response to tectonic forcing during the mid-Cretaceous: Paleoceanography, v. 17, n. 3, p. 1-29, http://dx.doi.org/10.1029/2001PA000623

Lehmann, C., Osleger, D. A., Montañez, I. P., Sliter, W., Arnaud-Vanneau, A., and Banner, J., 1999, Evolution of the Cupido and Coahuila carbonate platforms, early Cretaceous, northeastern Mexico: Geological Society of America Bulletin, v. 111, n. 7, p. 1010-1029, http://dx.doi.org/10.1130/00167606(1999) $111<1010:$ EOCACC $>2.3 . C O ; 2$

Loyd, S. J., Berelson, W. M., Lyons, T. W., Hammond, D. E., and Corsetti, F. A., 2012, Constraining pathways of microbial mediation for carbonate concretions of the Miocene Monterey Formation using carbonateassociated sulfate: Geochimica et Cosmochimica Acta, v. 78, p. 77-98, http://dx.doi.org/10.1016/ j.gca.2011.11.028

Machhour, L., Philip, J., and Oudin, J. L., 1994, Formation of laminite deposits in anaerobic-dysaerobic marine environments: Marine Geology, v. 117, n. 1-4, p. 287-302, http://dx.doi.org/10.1016/00253227(94) $90021-3$

Madigan, M. T., and Martinko, J. M., 2005, Brock Biology of Microorganisms, 11th edition: Upper Saddle River, New Jersey, Pearson Prentice Hall, 992 p.

Maher, K., Steefel, C. I., DePaolo, D. J., and Viani, B. E., 2006, The mineral dissolution rate conundrum: Insights from reactive transport modeling of $U$ isotopes and pore fluid chemistry in marine sediments: Geochimical et Cosmochimica Acta, v. 70, n. 2, p. 337-363, http://dx.doi.org/10.1016/j.gca.2005.09.001

Major, R. P., Lloyd, R. M., and Lucia, F. J., 1992, Oxygen isotope composition of Holocene dolomite formed 
in a humid hypersaline setting: Geology, v. 20, n. 7, p. 586-588, http://dx.doi.org/10.1130/00917613(1992) 020<0586:OICOHD > 2.3.CO;2

Mallory, F. B., Gordon, J. T., and Conner, R. L., 1963, The isolation of a pentacyclic triterpenoid alcohol from a protozoan: Journal of the American Chemical Society, v. 85, p. 1362-1363, http://dx.doi.org/ $10.1021 / \mathrm{ja00892 \textrm {a } 0 4 2}$

Manske, A. K., Glaeser, J., Kuypers, M. M. M., and Overmann, J., 2005, Physiology and phylogeny of green sulfur bacteria forming a monospecific phototrophic assemblage at a depth of 100 meters in the Black Sea: Applied and Environmental Microbiology, v. 71, n. 12, p. 8049-8060, http://dx.doi.org/10.1128/ AEM.71.12.8049-8060.2005

Maresca, J. A., Romberger, S. P., and Bryant, D. A., 2008, Isorenieratene biosynthesis in green sulfur bacteria requires the cooperative actions of two carotenoid cyclases: Journal of Bacteriology, v. 190, n. 19, p. 6384-6391, http://dx.doi.org/10.1128/JB.00758-08

Marshall, J. D., 1992, Climatic and oceanographic isotopic signals from the carbonate record and their preservation: Geological Magazine, v. 129, n. 2. p. 143-160, http://dx.doi.org/10.1017/ S0016756800008244

Maslen, E., Grice, K., Gale, J. D., Hallmann, C., and Horsfield, B., 2009, Crocetane: a potential marker of photic zone euxinia in thermally mature sediments and crude oils of Devonian age: Organic Geochemistry, v. 40, n. 1, p. 1-11, http://dx.doi.org/10.1016/j.orggeochem.2008.10.005

Maze, W. B., 1984, Jurassic La Quinta Formation in the Sierra de Perijá, northwestern Venezuela: Geology and tectonic environment of red beds and volcanic rocks, in Bonini, W. E., Hargraves, R. B., and Shagam, R., editors, The Caribbean-South American plate boundary and regional tectonics: Geological Society of America, Memoirs, v. 162, p. 263-282, http://dx.doi.org/10.1130/MEM162-p263

Mazzullo, S. J., 2000, Organogenic Dolomitization in Peritidal to Deep-Sea Sediments: Journal of Sedimentary Research, v. 70, n. 1, p. 10-23, http://dx.doi.org/10.1306/2DC408F9-0E47-11D7$8643000102 \mathrm{C} 1865 \mathrm{D}$

Mazzullo, S. J., and Friedman, G. M., 1977, Competitive algal colonization of peritidal flats in a schizohaline environment: The Lower Ordovician of New York: Journal of Sedimentary Research, v. 47, n. 1, p. 398-410, http://dx.doi.org/10.1306/212F7185-2B24-11D7-8648000102C1865D

McArthur, J. M., Howarth, R. J., and Bailey, T. R., 2001, Strontium Isotope Stratigraphy: LOWESS Version 3 : Best Fit to the Marine Sr-Isotope Curve for 0-509 Ma and Accompanying Look-up Table for Deriving Numerical Age: The Journal of Geology, v. 109, n. 2, p. 155-170, http://dx.doi.org/10.1086/319243

McCrea, J. M., 1950, On the isotopic chemistry of carbonates and a paleotemperature scale: The Journal of Chemical Physics, v. 18, p. 849-857, http://dx.doi.org/10.1063/1.1747785

Meister, P., Gutjahr, M., Frank, M., Bernasconi, S. M., Vasconcelos, C., and McKenzie, J. A., 2011, Dolomite formation within the methanogenic zone induced by tectonically driven fluids in the Peru accretionary prism: Geology, v. 39, n. 6, p. 563-566, http://dx.doi.org/10.1130/G31810.1

Méndez-Dot, J. A., Méndez-Baaamonde, J., Reyes, D., and Wilchy, R., 2015, The Cogollo Group and the Oceanic Anoxic Events 1a and 1b, Maracaibo Basin, Venezuela: Brazilian Journal of Geology, v. 45 , Supplement 1, p. 8-31, http://dx.doi.org/10.1590/2317-4889201530192

Menegatti, A. P., Weissert, H., Brown, R. S., Tyson, R. V., Farrimond, P., Strasser, A., and Caron, M., 1998, High-resolution $\delta^{13} \mathrm{C}$ stratigraphy through the Early Aptian "Livello Selli" of the Alpine Tethys: Paleoceanography, v. 13, n. 5, p. 530-545, http://dx.doi.org/10.1029/98PA01793

Moldowan, J. M., and Seifert, W. K., 1979, Head-to-head linked isoprenoid hydrocarbons in petroleum: Science, v. 204, n. 4389, p. 169-171, http://dx.doi.org/10.1126/science.204.4389.169

Moldowan, J. M., Seifert, W. K., and Gallegos, E. J., 1985, Relationship between petroleum composition and depositional environment of petroleum source rocks: American Association of Petroleum Geologists Bulletin, v. 69, n. 8, p. 1255-1268.

Moldowan, J. M., Fago, F. J., Lee, C. Y., Jacobson, S. R., Watt, D. S., Slougui, N. E., Jeganathan, A., and Young, D. C., 1990, Sedimentary 24- $n$-propylcholestanes, molecular fossils diagnostic of marine algae: Science, v. 247 , n. 4940, p. 309-312, http://dx.doi.org/10.1126/science.247.4940.309

Monteiro, F. M., Pancost, R. D., Ridgwell, A., and Donnadieu, Y., 2012, Nutrients as the dominant control on the spread of anoxia and euxinia across the Cenomanian - Turonian oceanic anoxic event (OAE2): Model-data comparison: Paleoceanography, v. 27, n. 4, p. 1-17, http://dx.doi.org/10.1029/ 2012PA002351

Moore, D. M., and Reynolds, R. C., 1989, X-ray diffraction and the identification and analysis of clay minerals: Oxford, Oxford University Press, 322 p.

Morford, J. L., and Emerson, S., 1999, The geochemistry of redox sensitive trace metal in sediments. Geochimica et Cosmochimica Acta, v. 63, n. 11-12, p. 1735-1750, http://dx.doi.org/10.1016/S00167037(99) 00126-X

Mutterlose, J., Pauly, S., and Steuber, T., 2009, Temperature controlled deposition of early Cretaceous (Barremian - early Aptian) black shales in an epicontinental sea: Palaeogeography, Palaeoclimatology, Palaeoecology, v. 273,n. 3-4, p. 330-345, http://dx.doi.org/10.1016/j.palaeo.2008.04.026

Naafs, B. D. A., Castro, J. M., De Gea, G. A., Quijano, M. L., Schmidt, D. N., and Pancost, R. D., 2016, Gradual and sustained carbon dioxide release during Aptian Oceanic Anoxic Event 1a: Nature Geoscience, v. 9, p. 135-139, http://dx.doi.org/10.1038/ngeo2627

Nägler, Th. F., Siebert, C., Lüschen, H., and Böttcher, M. E., 2005, Sedimentary Mo isotope record across the Holocene fresh-brackish water transition of the Black Sea: Chemical Geology, v. 219, n. 1-4, p. 283-295, http://dx.doi.org/10.1016/j.chemgeo.2005.03.006

Nance, W. B., and Taylor, S. R., 1976, Rare earth element patterns and crustal evolution: I. Australian post-Archean sedimentary rocks: Geochimica et Cosmochimica Acta, v. 40, n. 12, p. 1539-155, http:/ /dx.doi.org/10.1016/0016-7037(76)90093-4

Neunlist, S., and Rohmer, M., 1985, Novel hopanoids from the methylotrophic bacteria Methylococcus 
capsulatus and Methylomonas methanica (22S)-35-aminobacteriohopane-30,31,32,33,34-pentol and (22S)35-amino-3 beta-methylbacteriohopane-30,31,32,33, 34-pentol: Biochemical Journal, v. 231, n. 3, p. 635639, http://dx.doi.org/10.1042/bj2310635

Patton, J. W., Choquette, P. W., Guennel, G. K., Kaltenback, A. J., and Moore, A., 1984, Organic geochemistry and sedimentology of lower to mid-Cretaceous deep-sea carbonates, Sites 535 and 540, Leg 77: Initial Reports of the Deep Sea Drilling Project, v. 77, p. 417-443, http://dx.doi.org/10.2973/dsdp.proc. 77.110 .1984

Paytan, A., Kastner, M., and Chavez, F. P., 1996, Glacial to interglacial fluctuations in productivity in the Equatorial Pacific as indicated by marine barite: Science, v. 274, n. 5291, p. 1355-1357, http://dx.doi.org/ 10.1126 /science.274.5291.1355

Perez-Infante, J., ms, 1996, Global and local controls upon the deposition of organic-rich Cretaceous sequences of Western Venezuela: a geochemical study: Tyne, United Kingdom, University of Newcastle, Ph. D. thesis.

Peters, K. E., Walters, C. C., and Moldowan, J. M., 2005, The Biomarker Guide: Biomarkers and Isotopes in Petroleum Systems and Earth History: Cambridge, Cambridge University Press, 700 p.

Peterson, J. A., 1983, Petroleum geology and resources of south-eastern Mexico, northern Guatemala, and Belize: United States Geological Survey Circular, v. 760, 4 p.

Petrash, D. A., Lalonde, S. V., González-Arismendi, G., Gordon, R. A., Méndez, J. A., Gingras, M. K., and Konhauser, K. O., 2015, Can Mn-S redox cycling drive sedimentary dolomite formation? A hypothesis: Chemical Geology, v. 404, p. 27-40, http://dx.doi.org/10.1016/j.chemgeo.2015.03.017

Pöppelreiter, M., Balzarini, M. A., De Sousa, P., Engel, S., Galarraga, M., Hansen, B., Marquez, X., Morell, J., Nelson, R., and Rodriguez, F., 2005, Structural control on sweet-spot distribution in a carbonate reservoir: Concepts and 3-D models (Cogollo Group, Lower Cretaceous, Venezuela): American Association of Petroleum Geologists Bulletin, v. 89, n. 12, p. 1651-1676, http://dx.doi.org/10.1306/ 08080504126

Powell, T. G., and McKirdy, D. M., 1973, Relationship between ratio of pristane to phytane, crude oil composition and geological environment in Australia: Nature, v. 243, p. 37-39, http://dx.doi.org/ $10.1038 /$ physci243037a0

Poulton, S. W., and Canfield, D. E., 2005, Development of a sequential extraction procedure for iron: Implications for iron partitioning in continentally derived particulates: Chemical Geology, v. 214, n. 3-4, p. 209-221, http://dx.doi.org/10.1016/j.chemgeo.2004.09.003

2011, Ferruginous Conditions: A Dominant Feature of the Ocean through Earth's History: Elements, v. 7, n. 2, p. 107-112, http://dx.doi.org/10.2113/gselements.7.2.107

Poulton, S. W., and Raiswell, R., 2002, The low-temperature geochemical cycle of iron: From continental fluxes to marine sediment deposition: American Journal of Science, v. 302, n. 9, p. 774-805, http://dx.doi.org/10.2475/ajs.302.9.774

O'Neil, J. R., and Epstein, S., 1966, Oxygen isotope fractionation in the system dolomite-calcite- carbon dioxide: Science, v. 152, n. 3719, p. 198-201, http://dx.doi.org/10.1126/science.152.3719.198

Overmann, J., Cypionka, H., and Pfennig, N., 1992, An extremely low-light-adapted phototrophic sulfur bacterium from the Black Sea: Limnology and Oceanography, v. 37, n. 1, p. 150-155, http://dx.doi.org/ 10.4319/lo.1992.37.1.0150

Radke, M., Willsch, H., Leythaeuser, D., and Teichmüller, M., 1982, Aromatic components of coal: Relation of distribution pattern to rank: Geochimica et Cosmochimica Acta, v. 46, n. 10, p. 1831-1848, http:/ /dx.doi.org/10.1016/0016-7037(82)90122-3

Raederstorff, D., and Rohmer, M., 1984, Sterols of the unicellular algae Nematochrysopsis roscoffensis and Chrysotila lamellosa: Isolation of (24E)-24- $n$-propylidenecholesterol and 24- $n$-propylcholesterol: Phytochemistry, v. 23, n. 12, p. 2835-2838, http://dx.doi.org/10.1016/0031-9422(84)83024-1

Raiswell, R., 1988, Chemical model for the origin of minor limestone-shale cycles by anaerobic methane oxidation: Geology, v. 16, n. 7, p. 641-644, http://dx.doi.org/10.1130/0091-7613(1988)016<0641: CMFTOO $>2.3 . \mathrm{CO} ; 2$

Raiswell, R., and Canfield, D. E., 1998, Sources of iron for pyrite formation in marine sediments: American Journal of Science, v. 298, n. 3, p. 219-245, http://dx.doi.org/10.2475/ajs.298.3.219

Raiswell, R., and Fisher, Q. J., 2000, Mudrock-hosted carbonate concretions: a review of growth mechanism and their influence on chemical and isotopic composition: Journal of the Geological Society, London, v. 157, n. 1, p. 239-252, http://dx.doi.org/10.1144/jgs.157.1.239

Raiswell, R., Newton, R., and Wignall, P. B., 2001, An indicator of water-column anoxia: Resolution of biofacies variations in the Kimmeridge Clay (Upper Jurassic, UK): Journal of Sedimentary Research, v. 71, n. 2, p. 286-294, http://dx.doi.org/10.1306/070300710286

Renz, O., 1958, Estratigrafía del Cretáceo en Venezuela Occidental: Boletin del Ministerio de Minas e Hidrocarburos, v. 5 , n. 10, p. 3-48.

1981, Venezuela, in Reyment, R. A., and Bengtson., P., editors, Aspects of Mid-Cretaceous Regional Geology: New York, Academic Press, p. 197-220.

1982, The Cretaceous ammonites of Venezuela: Basel, Birkhauser Verlag, 132 p. (+ 40 plates).

Ricci, J. N., Coleman, M. L., Welander, P. V., Sessions, A. L., Summons, R. E., Spear, J. R., and Newman, D. K., 2013, Diverse capacity for 2-methylhopanoid production correlates with a specific ecological niche: The ISME Journal, v. 8, p. 675-684. http://dx.doi.org/10.1038/ismej.2013.191

Rickard, D., 2012, The Geochemistry of Sulfidic Sedimentary Rocks, in Rickard, D., editor, Sulfidic Sediments and Sedimentary Rocks: Developments in Sedimentology, v. 65, Chapter 15, p. 605-632, http://dx.doi.org/10.1016/B978-0-444-52989-3.00015-5

Ritger, S., Carson, B., and Suess, E., 1987, Methane-derived authigenic carbonates formed by subductioninduced pore-water expulsion along the Oregon/Washington margin: Geological Society of America Bulletin, v. 98, n. 2, p. 147-156, http://dx.doi.org/10.1130/0016-7606(1987) 98<147:MACFBS >2.0.CO;2 
Roberts, J. A., Bennett, P. C., González, L. A., Macpherson, G. L., and Milliken, K. L., 2004, Microbial precipitation of dolomite in methanogenic groundwater: Geology, v. 32, n. 4, p. 277-280, http:// dx.doi.org/10.1130/G20246.2

Rod, E., and Maync, W., 1954, Revision of Lower Cretaceous stratigraphy of Venezuela: American Association of Petroleum Geologists Bulletin, v. 38, n. 2, p. 193-283.

Rodriguez, N. M., Paull, C. K., and Borowski, W. S., 2000, Zonation of authigenic carbonates within gas hydrate-bearing sedimentary sections on the Blake ridge: Offshore southeastern North America, in Paull, C. K., Matsumoto, R., Wallace, P. J., and Dillon, W. P., editors, Proceedings of the Ocean Drilling Program, Scientific results, v. 164: College Station, Texas, Ocean Drilling Program, p. 301-312, http://dx.doi.org/10.2973/odp.proc.sr.164.227.2000

Rowland, S. J., 1990, Production of acyclic isoprenoid hydrocarbons by laboratory maturation of methanogenic bacteria: Organic Geochemistry v. 15, n. 1, p. 9-16, http://dx.doi.org/10.1016/0146$6380(90) 90181-X$

Rubinstein, I., Sieskind, O., and Albrecht, P., 1975, Rearranged sterenes in a shale: occurrence and simulated formation: Journal of the Chemical Society, Perkin Transactions 1, v. 1, n. 19, p. 1833-1836, http://dx.doi.org/10.1039/p19750001833

Sander, J., and Dahl, C., 2009, Metabolism of Inorganic Sulfur Compounds in Purple Bacteria, in Hunter, C. N., Daldal, F., Thurnauer, M. C., and Beatty, J. T., editors, The Purple Phototrophic Bacteria, Advances in Photosynthesis, v. 28: Dordrecht, Springer Science + Business Media B. V., p. 595-622.

Sass, E., and Bein, A., 1988, Dolomites and salinity: A comparative geochemical study, in Shukla, V., and Baker, P. A., editors, Sedimentology and Geochemistry of Dolostones: SEPM Special Publications, v. 43, p. 223-233, http://dx.doi.org/10.2110/pec.88.43.0223

Sass, E., and Katz, A., 1982, The origin of platform dolomites: New evidence: American Journal of Science, v. 282, n. 8, p. 1184-1213, http://dx.doi.org/10.2475/ajs.282.8.1184

Sauvage, L., Riquier, L., Thomazo, C., Baudin, F., and Martinez, M., 2013, The late Hauterivian Faraoni "Oceanic Anoxic Event" at Rio Argos (southern Spain): An assessment on the level of oxygen depletion: Chemical Geology, v. 340, p. 77-90, http://dx.doi.org/10.1016/j.chemgeo.2012.12.004

Scheller, S., Yu, H., Chadwick, G. L., Mcglynn, S. E., and Orphan, V. J., 2016, Artificial electron acceptors decouple archaeal methane oxidation from sulfate reduction: Science, v. 351, n. 674, p. 703-707, http://dx.doi.org/10.1126/science.aad7154

Schijf, J., and Marshall, K. S., 2011, YREE sorption on hydrous ferric oxide in 0. $5 \mathrm{M} \mathrm{NaCl} \mathrm{solutions:} \mathrm{A}$ model extension: Marine Chemistry, v. 123, n. 1-4, p. 32-43, http://dx.doi.org/10.1016/ j.marchem.2010.09.003

Schinteie, R., ms, 2011, Ancient Life at the Extremes: Molecular Fossils and Paleoenvironmental Contexts of Neoproterozoic and Cambrian Hypersaline Settings: Canberra, Australia, The Australian National University, Ph. D. thesis.

Schinteie, R., and Brocks, J. J., 2014, Evidence for ancient halophiles? Testing biomarker syngeneity of evaporites from Neoproterozoic and Cambrian strata: Organic Geochemistry, v. 72, p. 46-58, http:// dx.doi.org/10.1016/j.orggeochem.2014.04.009

Schlanger, S. O., and Jenkyns, H. C., 1976, Cretaceous oceanic anoxic events: Causes and consequences: Geologie en Mijnbouw, v. 55, n. 3-4, p. 179-184.

Schoell, M., McCaffrey, M. A., Fago, F. J., and Moldowan, J. M., 1992, Carbon isotopic compositions of 28,30-bisnorhopanes and other biological markers in a Monterey crude oil: Geochimica et Cosmochimica Acta, v. 56, n. 3, p. 1391-1399, http://dx.doi.org/10.1016/0016-7037(92)90070-Y

Schwark, L., and Empt, P., 2006, Sterane biomarkers as indicators of Palaeozoic algal evolution and extinction events: Palaeogeography, Palaeoclimatology, Palaeoecology, v. 240, n. 1-2, p. 225-236, http://dx.doi.org/10.1016/j.palaeo.2006.03.050

Schwark, L., and Frimmel, A., 2004, Chemostratigraphy of the Posidonia black shale, SW-Germany: II Assessment of extent and persistence of photic-zone anoxia using aryl isoprenoid distributions: Chemical Geology, v. 206, n. 3-4, p. 231-248, http://dx.doi.org/10.1016/j.chemgeo.2003.12.008

Schweitzer, C. E., Lacovara, K. J., Smith, J. B., Lamanna, M. C., Lyon, M. A., and Attia, Y., 2003, Mangrove dwelling crabs (Decapoda: Brachyura: Necrocarcinidae) associated with dinosaurs from the upper Cretaceous (Cenomanian) of Egypt: Journal of Paleontology, v. 77, n. 5, p. 888-894, http:/ /dx.doi.org/ 10.1666/0022-3360(2003) 077<0888:MCDBNA > 2.0.CO;2

Shen, Y. N., Canfield, D. E., and Knoll, A. H., 2002, Middle Proterozoic ocean chemistry: Evidence from the McArthur Basin, northern Australia: American Journal of Science, v. 302, n. 2, p. 81-109, http:// dx.doi.org/10.2475/ajs.302.2.81

Simonin, P., Tindall, B., and Rohmer, M., 1994, Structure elucidation and biosynthesis of 31-methylhopanoids from Acetobacter europaeus: European Journal of Biochemistry, v. 225, n. 2, p. 765-771, http://dx.doi.org/10.1111/j.1432-1033.1994.00765.x

Sinninghe-Damsté, J. S., Kenig, F., Koopmans, M. P., Köster, J., Schouten, S., Hayes, J. M., and de Leeuw, J. W., 1995, Evidence for gammacerane as an indicator of water column stratification: Geochimica et Cosmochimica Acta, v. 59, n. 9, p. 1895-1900, http://dx.doi.org/10.1016/0016-7037(95)00073-9

Smith, J. B., Lamanna, M. C., Lacovara, K. J., Dodson, P., Smith, J. R., Poole, J. C., Giegengack, R., and Attia, Y., 2001, A giant sauropod dinosaur from an Upper Cretaceous mangrove deposit in Egypt: Science, v. 292, n. 5522, p. 1704 - 1706, http://dx.doi.org/10.1126/science.1060561

Staudt, W. J., Oswald, E. J., and Schoonen, M. A. A., 1993, Determination of sodium, chloride and sulfate in dolomites: A new technique to constrain the composition of dolomitizing fluids: Chemical Geology, v. 107, n. 1-2, p. 97-109, http://dx.doi.org/10.1016/0009-2541(93)90104-Q

Stephens, N. P., and Carroll, A. R., 1999. Salinity stratification in the Permian Phosphoria sea: A proposed paleoceanographic model: Geology, v. 27, n. 10, p. 899-902, http://dx.doi.org/10.1130/00917613(1999)027<0899:SSITPP>2.3.CO;2 
Summons, R. E., and Jahnke, L. L., 1992, Hopenes and hopanes methylated in ring-A: Correlation of the hopanoids from extant methylotrophic bacteria with their fossil analogues, in Moldowan, J. M., Albrecht, P., and Philp, R. P., editors, Biological markers in sediments and petroleum: Englewood Cliffs, New Jersey, Prentice Hall, p. 182-200.

Summons, R., and Powell, T., 1987, Identification of aryl isoprenoids in source rocks and crude oils: Biological markers for the green sulphur bacteria: Geochimica et Cosmochimica Acta, v. 51, n. 3, p. 557-566, http://dx.doi.org/10.1016/0016-7037(87)90069-X

Summons, R. E., Jahnke, L. L., Hope, J. M., and Logan, G. A., 1999, 2-Methylhopanoids as biomarkers for cyanobacterial oxygenic photosynthesis: Nature, v. 400, p. 554-557, http://dx.doi.org/10.1038/23005

Sutton, F. A., 1946, Geology of Maracaibo Basin, Venezuela: American Association of Petroleum Geologists Bulletin, v. 30, n. 10, p. 1621-1741.

Sun, S. Q., 1994, A Reappraisal of Dolomite Abundance and Occurrence in the Phanerozoic: Journal of Sedimentary Research, v. 64, n. 2a, p. 396-404, http://dx.doi.org/10.1306/D4267DB1-2B26-11D78648000102C1865D

Tejada, M. L. G., Suzuki, K., Kuroda, J., Coccioni, R., Mahoney, J. J., Ohkouchi, N., Sakamoto, T., and Tatsumi, Y., 2009, Ontong Java plateau eruption as a trigger for the early Aptian oceanic anoxic event: Geology, v. 37, n. 9, p. 855-858, http://dx.doi.org/10.1130/G25763A.1

Ten Haven, H. L., De Leeuw, J. W., Sinninghe-Damsté, J. S., Schenck, P. A., Palmer, S. E., and Zumberge, J. E., 1988, Application of biological markers in the recognition of palaeohypersaline environments: Geological Society, London, Special Publications, v. 40, p. 123-130, http://dx.doi.org/10.1144/ GSL.SP.1988.040.01.11

Thomazo, C., Vennin, E., Brayard, A., Bour, I., Mathieu, O., Elmeknassi, S., Olivier, N., Escarguel, G., Bylund, K. G., Jenks, J., Stephen, D. A., and Fara, E., 2016, A diagenetic control on the Early Triassic Smithian-Spathian carbon isotopic excursions recorded in the marine settings of the Thaynes Group (Utah, USA): Geobiology, v. 14, n. 3, p. 220-236, http://dx.doi.org/10.1111/gbi.12174

Tissot, B. P., and Welte, D. H., 1984, Petroleum formation and occurrence. A New Approach to Oil and Gas Exploration: Berlin, Springer-Verlag, 702 p.

Torres, M. E., Brumsack, H. J., Bohrmann, G., and Emeis, K. C., 1996, Barite fronts in continental margin sediments: A new look at barium remobilization in the zone of sulfate reduction and formation of heavy barites in diagenetic fronts: Chemical Geology, v. 127, n. 1-3, p. 125-139, http://dx.doi.org/10.1016/ 0009-2541(95)00090-9

Trüper, H. G., and Pfennig, N., 1992, The family Chlorobiaceae, in Balows, A., Trüper, H. G., Dworkin, M., Harder, W., and Schleifer, K. H., editors, The Prokaryotes-A handbook on the biology of bacteriaEcophysiology, isolation, identification applications: New York, Springer, p. 3583-3592.

Vahrenkamp, V. C., Franssen, R. C. W. M., Grötsch, J., and Munoz, P. J., 1993, Maracaibo Platform (Aptian-Albian), northwestern Venezuela, in Simo, J. A. T., Scott, R. W., and Masse, J. P., editors, Cretaceous Carbonate Platforms: American Association of Petroleum Geologists Memoir, v. 25, p. 2533.

van Kaam-Peters, H. M. E., Köster, J., van der Gaast, S. J., Dekker, M., de Leeuw, J. W., and Sinninghe Damsté, J. S., 1998, The effect of clay minerals on diasterane/sterane ratios: Geochimica et Cosmochimica Acta, v. 62, n. 17, p. 2923-2929, http://dx.doi.org/10.1016/S0016-7037(98)00191-4

Venkatesan, M. I., 1989, Tetrahymanol: Its widespread occurrence and geochemical significance: Geochimica et Cosmochimica Acta, v. 53, n. 11, p. 3095-3101, http://dx.doi.org/10.1016/0016-7037(89)90190-7

Ventura, M., Canchaya, C., Tauch, A., Chandra, G., Fitzgerald, G. F., Chater, K. F., and van Sinderen, D., 2007, Genomics of Actinobacteria: Tracing the evolutionary history of an ancient phylum: Microbiology and Molecular Biology Reviews, v. 71, n. 3, p. 495-548, http://dx.doi.org/10.1128/MMBR.00005-07

Visscher, P. T., and Stolz, J. F., 2005, Microbial mats as bioreactors: Populations, processes, and products: Palaeogeography, Palaeoclimatology, Palaeoecology, v. 219, n. 1-2, p. 87-91, http://dx.doi.org/10.1016/ j.palaeo.2004.10.016

Volkman, J., 2003, Sterols in microorganisms, Applied Microbiology and Biotechnology, v. 60, n. 5, p. 495-506, http://dx.doi.org/10.1007/s00253-002-1172-8

Volkman, J. K., 1986, A review of sterol markers for marine and terrigenous organic matter. Organic Geochemistry, v. 9, n. 2, p. 83-99, http://dx.doi.org/10.1016/0146-6380(86)90089-6

Von Breymann, M. T., Emeis, K. C., and Suess, E., 1992, Water depth and diagenetic constraints on the use of barium as a paleoproductivity indicator, in Summer-Hayes, C. P., Prell, W. L., and Emeis, K. C., editors, Upwelling Systems: Evolution since the Early Miocene: Geological Society, London, Special Publications, v. 64, p. 273-284, http://dx.doi.org/10.1144/GSL.SP.1992.064.01.18

Wagner, T., Hofmann, P., and Flögel, S., 2013, Marine black shale deposition and Hadley Cell dynamics: A conceptual framework for the Cretaceous Atlantic Ocean: Marine and Petroleum Geology, v. 43, p. 222-238, http://dx.doi.org/10.1016/j.marpetgeo.2013.02.005

Wang, C., 2007, Anomalous hopane distributions at the Permian-Triassic boundary, Meishan, ChinaEvidence for the end-Permian marine ecosystem collapse: Organic Geochemistry, v. 38, n. 1, p. 52-66, http://dx.doi.org/10.1016/j.orggeochem.2006.08.014

Wedepohl, K. H., 1978, Manganese: Abundance in common sediments and sedimentary rocks, in Wedepohl, K. H., editor, Handbook of Geochemistry: Berlin, Springer, p. 1-17.

Weedon, G. P., 1986, Hemipelagic shelf sedimentation and climatic cycles: The basal Jurassic (Blue Lias) of South Britain: Earth and Planetary Science Letters, v. 76, n. 3-4, p. 321-335, http://dx.doi.org/10.1016/ 0012-821X(86)90083-X

Weedon, G. P., and Hallam, A., 1987, Comment and Reply on "Origin of minor limestone-shale cycles: Climatically induced or diagentic”: Geology, v. 15, p. 92-94, http://dx.doi.org/10.1130/00917613(1987) $15<92:$ CAROOO $>2.0$. CO;2 
Westphal, H., and Munnecke, A., 2003, Limestone-marl alternations: A warm-water phenomenon?: Geology, v. 31, n. 3, p. 263-266, http://dx.doi.org/10.1130/0091-7613(2003)031<0263:LMAAWW>2.0.CO;2

Wignall, P. B, 1994, Black shales: Oxford, Oxford University Press, 127 p.

Wignall, P. B., and Newton, R., 1998, Pyrite framboid diameter as a measure of oxygen deficiency in ancient mudrocks: American Journal Science, v. 298, n. 7, p. 537-552, http://dx.doi.org/10.2475/ajs.298.7.537

Wilkin, R. T., Barnes, H. L., and Brantley, S. L., 1996, The size distribution of framboidal pyrite in modern sediments: An indicator of redox conditions: Geochimica et Cosmochimica Acta, v. 60, n. 20, p. $3897-$ 3912, http://dx.doi.org/10.1016/0016-7037(96)00209-8

Yurewicz, D. A., Advocate, D. M., Lo, H. B., and Hernández, E. A., 1998, Source rocks and oil families, southwest Maracaibo Basin (Catatumbo Sub-basin), Colombia: American Association of Petroleum Geologists Bulletin, v. 82, n. 7, p. 1329-1352.

Zheng, Y., Anderson, R. F., van Geen, A., and Kuwabara, J., 2000, Authigenic molybdenum formation in marine sediments: A link to pore water sulphide in the Santa Barbara Basin: Geochimica et Cosmochimica Acta, v. 64, n. 24, p. 4165-4178, http://dx.doi.org/10.1016/S0016-7037(00)00495-6

Zeebe, R. E., and Wolf-Gladrow, D., 2001, $\mathrm{CO}_{2}$ in seawater: Equilibrium, Kinetics, Isotopes: Amsterdam, Elsevier Science, $360 \mathrm{p}$

Zumberge, J. E., 1987, Prediction of source rock characteristics based on terpane biomarkers in crude oils: A multivariate statistical approach: Geochimica et Cosmochimica Acta, v. 51, n. 6, p. 1625-1637, http://dx.doi.org/10.1016/0016-7037(87)90343-7 